\title{
Ekecikdağ Magmatik Birliği (Orta Anadolu) Granitoyidlerinin Petrojenezi: Mineral Kimyası Perspektifi
}

\section{Petrogenesis of the Ekecikdağ Igneous Association (Central Anatolia): Mineral Chemistry Perspective}

\section{FATMA TOKSOY-KÖKSAL}

Orta Doğu Teknik Üniversitesi, Jeoloji Mühendisliği Bölümü, Ankara

\author{
Geliș (received) : : 28 Șubat (February) 2016 \\ Kabul (accepted) : 27 Temmuz (July) 2016
}

\section{Öz}

Ekecikdağ Magmatik Birliği (EMB), Orta Anadolu Kristalen Kompleksi'ndeki çarpıșma-çarpıșma sonrası granitoyidlerdendir. Değișen oranlarda amfibol, biyotit, muskovit, plajiyoklaz, alkali-feldispat, kuvars ana mineralleri ve apatit, zirkon, titanit, manyetit aksesuar minerallerini içeren birlik granodiyorit, mikrogranit ve lökogranit bileșimli kayaçlardan olușmaktadır. Ana granitik faz, mafik mikrogranüler anklav, iri K-feldispat kristali, bol biyotit ve amfibol (\% 45-55) içeren faneritik porfiritik dokulu granodiyorittir. Koyu gri mikrogranüler mikrogranit ve orta-eșit tane dokulu, \% 5-15 mafik mineral içeren pembemsi beyaz lökogranit, iki mikalı (biyotit+muskovit) granitoyidlerdir.

Tüm-kayaç element verileri, granitoyidlerin kalk-alkalen, yüksek potasik, S- ve I-tipi karakterde olduklarını göstermektedir. Çoklu element dağılım grafiklerinde negatif $\mathrm{Ba}, \mathrm{Nb}, \mathrm{Sr}, \mathrm{P}, \mathrm{Eu}, \mathrm{Ti}$ anomalileri ve nadir toprak element (NTE) grafiklerinde hafif NTE zenginleșmesi karakteristiktir. La, Eu ve Ce negatif anomali gösterirken, Th, U ve Pb pozitif anomali göstermektedir. Lökogranit diğerlerine göre düșük hafif NTE ve yüksek ağır NTE değerleri göstermektedir. Granodiyoritle mikrogranitin NTE dağılımları, magma kaynağında granatın / hornblendin birikmesini vermektedir.

Kayaçlardaki amfibol, biyotit, feldispat ve oksitlerin kimyasal bileșimleri petrolojik özellikler ve yerleșim koșullarının belirlenmesinde kullanılmıștır. Granodiyoritte bulunan amfibol kalsik alt grubundan olup magnezyum-hornblend bileșimindedir. Üç kayaç tipinde de bulunan biyotit Mg'ca zengin olup yüksek $\mathrm{Fe}^{3+} /\left(\mathrm{Fe}^{2+}+\mathrm{Fe}^{3+}\right)$ oranlarına sahiptir. Alkali-feldispat tüm kayaçlarda $\mathrm{Or}_{85-98}$

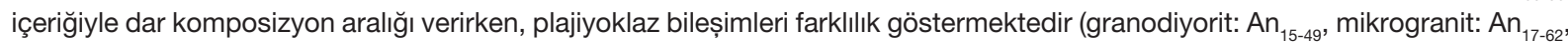
lökogranit: $A n_{1-17}$. Oligoklaz tüm kayaç tiplerinde tanımlanmıștır. Mineral kimyası verileri, granodiyorit ve lökogranitin kalk-alkalen, mikrogranitin peralüminalı karakteri ve granodiyoritin hibridik kökenini ortaya koymaktadır. Ayrıca, kayaçların farklı kökenlere sahip olup değișik oranlarda manto katkılı(?) meta-magmatik ve meta-sedimenter kabuksal kaynaklardan türediklerine ișaret etmektedir.

Jeotermometrik hesaplamalar magmatikten sub-solidusa geniș aralıkta sıcaklık (granodiyorit: $615-783^{\circ} \mathrm{C}$, mikrogranit: 464 $565^{\circ} \mathrm{C}$, lökogranit: $456-482^{\circ} \mathrm{C}$ ) vermiștir. Düșük değerler, yavaș soğuma sırasında geç evrede yeniden dengelenmeye ișaret etmektedir. Jeobarometrik hesaplamalar, jeoloji ve mineral toplulukları yerleșim derinliğinin orta kabuksal seviyelere karșlık geldiğini ortaya koymaktadır (granodiyorit: 3-4.5 kbar / 10-16 km, mikrogranit-lökogranit: 3.3-3.6 kbar / 11-12 km). Oksijen fugasitesi yüksektir (HM-FMQ).

Anahtar Kelimeler: Ekecikdağ, granitoyid, mineral kimyası, Orta Anadolu.

\section{ABSTRACT}

Ekecikdağ Igneous Association (EIA) belongs to syn- and post-collisional granitoids within Central Anatolian Crystalline Complex. The association, with variable essentials of amphibole, biotite, muscovite, plagioclase, alkali-feldspar, quartz and accessories of apatite, zircon, titanite, magnetite, is made of granodiorite, microgranite and leucogranite. Granodiorite is main granitic phase with mafic microgranular enclaves, K-feldspar phenocrysts, high biotite and amphibole contents (45-55 \%) and phaneritic porphyritic texture. Dark-grey microgranular microgranite and medium-equigranular pinkish white leucogranite with low mafic content (5-15\%) are two-mica (biotite+muscovite) granitoids.

${ }^{*}$ F. Köksal

e-posta: ftkoksal@metu.edu.tr 
Whole-rock element data reveal that granitoids are high-K calc-alkaline, S- and I-type. Negative Ba, Nb, Sr, P, Eu and Ti anomalies on multi-element diagrams and LREE enrichment on REE diagrams are characteristic. La, Eu and Ce display negative anomalies while $T h, U$ and $P b$ have pozitif anomalies. REE patterns of granodiorite and microgranite infer accumulation of garnet / hornblende in magma source.

Mineral chemistry data from amphibole, biotite, feldspar and oxides are used for interpretation of petrological features and emplacement conditions. Amphibole in granodiorite is of calcic subgroup and magnesium hornblende in composition. Biotite in all rock types is $\mathrm{Mg}$-rich and high $\mathrm{Fe}^{3+} /\left(\mathrm{Fe}^{2+}+\mathrm{Fe}^{3+}\right)$. Alkali-feldspars are limited to narrow $\mathrm{Or}_{85-98}$ range while plagioclase have variable compositions (granodiorite: $A n_{15-49}$, microgranite: $A n_{17-62}$, leucogranite: $\left.A n_{1-17}\right)$. Mineral chemistry infers calc-alkaline character of granodiorite and leucogranite, peraluminous character of microgranite, and hybridic origin of granodiorite. Moreover, it suggests that granitoids are genetically different, and derived from meta-magmatic and meta-sedimentary continental crustal material with mantle material contributing(?) in variable amounts.

Geothermometric calculations give magmatic to sub-solidus temperatures (granodiorite: $615-783^{\circ} \mathrm{C}$, microgranite: $464-565^{\circ} \mathrm{C}$, leucogranite: $456-482^{\circ} \mathrm{C}$ ). Low temperatures infer recrystallization at late stage during slow cooling. Geobarometric calculations, geology and mineral assemblages suggest emplacement depth of the granitoids corresponds to mid-crustal levels (granodiorite: 3-4.5 kbar / 10-16 km, microgranite-leucogranite: 3.3-3.6 kbar / 11-12 km). Oxygen fugacity is high (HM-FMQ).

Keywords: Central Anatolia, Ekecikdağ, granitoid, mineral chemistry.

\section{GiRiș}

Ekecikdağ Magmatik Birliği (EMB) Orta Anadolu'daki en önemli magmatik birliklerden birisi olup Tuz Gölü'nün doğusunda Aksaray civarında bulunan Ekecikdağ bölgesinde yer almaktadır (Șekil 1b). 200 $\mathrm{km}^{2}$ 'den büyük bir alanı kapsayan EMB kuzeybatıgüneydoğu yönünde uzanmaktadır.

EMB'deki öncel çalıșmalar Türeli (1991), Türeli vd. (1993), Göncüoğlu ve Türeli $(1993,1994)$ tarafından yapılmıștır. Bu çalıșmalarda; detay saha jeolojisi, petrografi, tüm-kayaç element ve sınırı miktarda izotop verileriyle jeokimyasal özellikleri incelenerek EMB'nin petrolojisi değerlendirilmiștir. Bu alanda daha sonra Göncüoğlu vd. (2004), Köksal (2005) ve Köksal vd. (2008) tarafından yapılan çalıșmalar ise EMB'de bulunan granitik kayaçların zirkon tipolojisi ve zirkon kimyası özelliklerinin incelenmesini içermiștir. Toksoy-Köksal vd. $(2008,2009 a)$ ise bu kayaçların jeokimyasal ile izotopik özellikleri ve U-Pb zirkon yașlarının belirlenmesini kapsayan bir çalıșma yapmıștır.

Orta Anadolu'da yaygın olarak yüzeylenen Orta Anadolu Granitoyidleri (OAG) birçok jeolojik ve petrolojik çalıșmaya konu olmuștur (Erler vd., 1991; Göncüoğlu vd., 1991, 1992; Akıman vd., 1993; Yalııı vd., 1999; Boztuğ, 2000; Köksal vd., 2001, 2004, 2012, 2013; Whitney vd., 2001; Illbeyli, 2005; Boztuğ vd., 2007b, 2008, 2009; Delibaș vd., 2011). Ancak, bu granitoyidleri mineraloji ve mineral kimyası kullanarak irdeleyen çalıșmalar jeotermobarometrik hesaplamalar ve oksijen fugasitesi belirleme ile sınırlı kalmıștır (Illbeyli,
2005; Boztuğ vd., 2007a, 2009). Oysa, magmatik kayaç olușturan ergiyiğin jeokimyasal özellikleri ile evrimleșme süreç ve koșulları, kayacı olușturan mineral toplulukları ve minerallerin kimyasal içerikleri ile yakından ilgilidir (Abbott, 1985). OAG'nden Ekecikdağ granitoyidi hakkında olan bu çalıșmanın amacı; tümkayaç element jeokimyası destekli detaylı mineral kimyası verilerini irdeleyerek, 1) mineral kimyasının petrolojik anlamlarını saptamak, 2) magmanın kristallenmesi sırasında etkin olan sıcaklık, basınç ve oksijen fugasite gibi fizikokimyasal özelliklerini belirlemek, 3) OAG'nin kökeni ve yerleșim koșulları konusunda literatüre katkı yapmaktır.

\section{BÖLGESEL JEOLOJi}

Çalıșma alanının bulunduğu Orta Anadolu Bölgesi'ndeki metamorfik, granitik ve ofiyolitik birimler topluluğu, Orta Anadolu Kristalen Karmașı̆ı (OAKK) olarak adlandırımıștır (Göncüoğlu vd., 1991) (Șekil 1a, b). OAKK'nin çökel kökenli temel kayaç birimleri; altta Prekambriyen ve erken Paleozoyik meta-kırıntıı ve meta-magmatik kayaçlar (para-ortognays ve nadir karbonat arabantlı șistler), üstte ise geç Paleozoyik ve Mesozoyik meta-kırıntılı kayaçlar, kalk-șist ve mermerlerden olușmaktadır (Șekil 1b). Bu metamorfik kayaçlar 'dalma-batma zonu üstü' tipteki ofiyolitik kayaçlarla üzerlenmekte ve granitik sokulumlarca kesilmektedirler (Erler vd., 1991; Göncüoğlu vd., 1991, 1992; Akıman vd., 1993; Boztuğ, 2000; Boztuğ vd., 2007a, b, 2008, 2009; Yalınız vd., 1999; Köksal vd., 

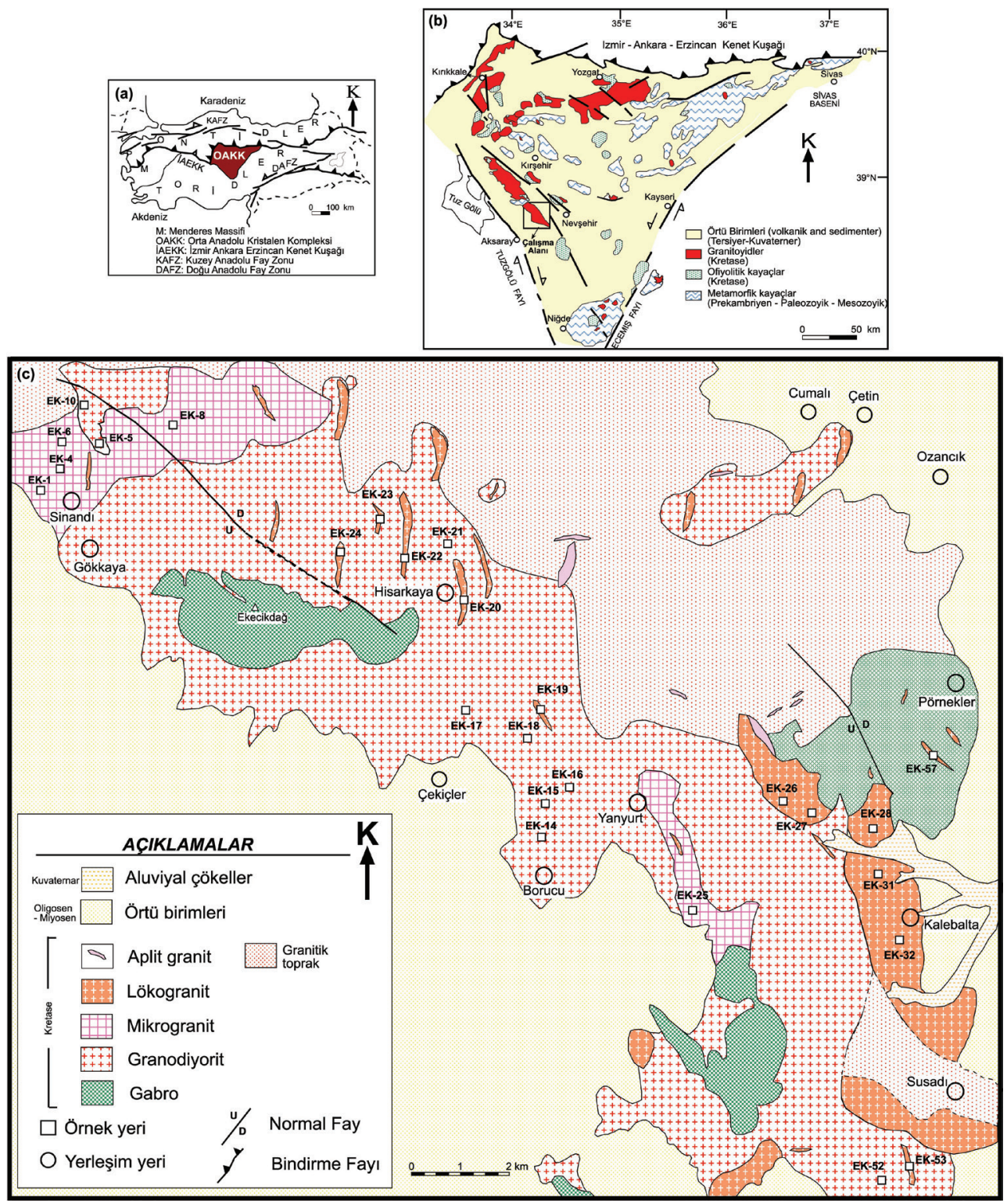

Șekil 1. (a) Orta Anadolu Kristalen Kompleksi'nin Türkiye tektonik çerçevesindeki konumu, (b) Çalıșma alanı olan Ekecikdağ Magmatik Birliği (EMB)'nin Orta Anadolu Kristalen Karmașığı içerisindeki konumunu gösterir harita (Göncüoğlu vd. (1991), Yalınız ve Göncüoğlu (1998)'ndan revize edilmiștir), (c) Ekecikdağ Bölgesi'nin jeolojik haritası (Türeli (1991)'den revize edilmiștir) ve örnek lokasyonları.

Figure 1. (a) Location of the Central Anatolian Crystalline Complex in tectonic framework of Turkey, (b) Location of Ekecikdağ Magmatic Association (EMA) in the Central Anatolian Crystalline Complex (modified from Göncüoğlu et al. (1991), Yalınız and Göncüoğlu (1998)), (c) Geological map of the Ekecikdağ area (modified from Türeli, 1991) and sample locations.

2001, 2004, 2012, 2013; Whitney vd., 2001; İlbeyli, 2005). Bu birimlerin üstündeki, metamorfik olmayan Üst-Maestrihtiyen-Alt Paleosen örtü birimleri, Paleosen-Eosen volkanik, volkaniklastik ve karbonat kayaçlarla örtülmekte, Oligosen-Miyosen evaporitleri ve karasal klastikler ile volkaniklastik ve volkanik kayaçlar ise, OAKK'nın daha genç örtü birimlerini temsil etmektedir (Göncüoğlu vd., 1991; Köksal vd., 2001).

OAKK granitoyidlerinin olușumları hakkında farklı görüșler vardır. Torid bloğunu Anatolid bloğundan ayıran İç Toros Kușağının varlığını savunan Görür vd. (1984), Șengör ve Yılmaz (1981), Okay vd. (1996), Kadıoğlu vd. (2003), Deniz ve Kadıoğlu (2016)'na göre 
İç Torid okyanusal litosferi Paleosen-Erken Eosen'de Kırșehir Bloğu altına dalmıș ve Kırșehir-Aksaray yöresinde yay (And tipi) granitoyidler olușmuștur. Buna karșılık Kadıoğlu vd. (2006), bu granitlerin Toros Platformu ile İç Torid Okyanusu içerisindeki bir hendeğin çarpıșması ve bir miktar dalmasını takip eden dilim-kopması (slab break-off) ile astenosfer yükselimi ve dalma sonucu metasomatize olan litosferik manto kaynaklı olduğunu ileri sürmüștür. Ancak Kırșehir bloğunu Torid platformundan ayıran İç Torid Okyanusu'nun olmadığını savunan araștırmacılara (Göncüoğlu vd., 1997; Boztuğ vd., 2009; Köksal vd., 2012, 2013; Hinsbergen vd., 2016) göre OAG Pontidlerin Torid-Anatolid platformu ile çarpıșması ve çarpıșma sonrası gerilme rejiminde gelișmișlerdir (Göncüoğlu vd., 1997; Göncüoğlu ve Türeli, 1993, 1994; Erler ve Göncüoğlu, 1996; Aydın vd., 1998; Düzgören-Aydın vd., 2001; Boztuğ, 1998, 2000; Boztuğ vd., 2007a, b, 2008, 2009; Otlu ve Boztuğ, 1998; Tatar and Boztuğ, 1998; Yılmaz ve Boztuğ, 1998; Yalınız vd., 1999; Köksal vd., 2004, 2012, 2013; Delibaș vd., 2011). Bu araștırmacılara göre, erken-geç Kretase'de Alpin Orojenezi Neotetisin kuzey kolu İzmir-AnkaraErzincan Okyanusunun (IAEO) okyanus içi dalmanın eșlik ettiği jeodinamik mekanizmayla kapanımına, Pontid volkanik yayı ile Torid-Anatolid'in kuzey kısmın çarpıșmasına, Torid-Anatolid Platformunun pasif kenarınının dilimlenerek kalınlașmasıyla orta-yüksek derecede metamorfizmasına ve üzerine ofiyolitik birimlerin yerleșimine yol açmıștır. Temel birimler üzerine ofiyolitik dilimlerin yerleșmesiyle kalınlașan kabuğun gerilmesi basınç azalmasını beraberinde getirmiș ve Kretase sonunda 'çarpıșma ile ilișkili' magmatizmaya neden olmuștur.

Farklı mineraloji ve kompozisyonlara sahip OAG Pitcher (1993) sınıflamasına göre S- (sedimenter), I- (magmatik), A- (alkalen) olmak üzere üç gruptur. S-tipi granitoyidler lökogranitik veya nadiren granodiyoritik bileșimli, peralüminalı ve çift mikalı olup çarpıșma eș zamanlı sedimenter kökenlidirler (Göncüoğlu vd., 1991, 1992, 1993; Göncüoğlu ve Türeli, 1993, 1994; Akıman vd., 1993; Türeli vd., 1993; Erler ve Göncüoğlu, 1996; Yalınız vd., 1999; Boztuğ vd., 2007b). OAGnin büyük bölümünü olușturan I- ve A-tipi granitoyidler ise genel olarak granitik ve monzonitik bileșime sahip olup kalk-alkalen metalümin karakterdeki çarpıșma sonrası granitoyidlerdir ve manto kökenli mafik magma ile kabuksal kökenli felsik magmanın karıșımı sonucu olușmușlardır (Tatar ve Boztuğ, 1998; Yılmaz ve Boztuğ, 1998; Yalınız vd.,
1999; Boztuğ, 2000; Boztuğ vd., 2007a, 2009; Köksal vd., 2001, 2012, 2013; illbeyli, 2005; Delibaș vd., 2011). Arazi yayılımları nispeten az olan siyenitik (kuvars-siyenitik veya foid-siyenitik) bileșimdeki granitoyidler ise yer yer I-tipi granitoyidlerle birliktelik oluștururken, yer yer de onları kesmektedir (Göncüoğlu vd., 1997; Otlu ve Boztuğ, 1998; Boztuğ, 2000; Boztuğ vd., 2007b, 2008, 2009; Köksal vd., 2001, 2004).

OAKK granitoyidlerini kalk-alkalen, sub-alkalengeçișli ve alkalen olmak üzere üç gruba ayıran İlbeyli vd. (2004), bu kayaçların birliktelik olușturmalarını çarpıșma öncesi manto kaynağındaki heterojeniteyle açıklamakta ve Orta Anadolu'da gerilme tektoniği olmadığı görüșüyle, OAG'nin olușumunu, termal sınır tabakasının delaminasyonuyla metasomatize litosferin yukarı çıkıșına veya yitmiș tabakanın yok olmasına yol açan dilim-kopması olayına bağlamaktadır. Köksal vd. (2004) ise I- ve A-tipi granitoyidlerin Alpin Orojenezinde çarpıșmayla kabuk kalınlașmasını ve çarpıșma sonrası gelișen gerilme rejimine bağlı olarak heterojen bir mantodan farklı oranlarda kıtasal kabuk kirlenmesi sonucu oluștuğunu ileri sürmektedir. Boztuğ vd. (2007a, 2008, 2009) de aynı șekilde Orta Anadolu'daki granitlerinin olușumunu çarpıșma sonrası gerilme rejimine bağlamaktadır.

Yukarıda görüldüğü üzere; OAG birçok jeolojik ve petrolojik çalıșmaya konu olmuș ancak kökenleri ve olușumları konusunda araștırmacılar arasında bir fikir birliği olușmamıștır. Öncel çalıșmalardaki petrolojik değerlendirmeler tüm-kayaç element ve izotop jeokimyası verileriyle sınırlı kalmıștır. Ayrıca, bölge jeodinamiğinin tartıșılmasında önemli olan magma yerleșim koșullarına yönelik çalıșmalarda oldukça sınırIıdır (Otlu vd., 2001; illbeyli, 2005; Boztuğ vd., 2007a, 2009). OAKK granitoyidlerinde yapılan öncel çalıșmalarda mineral kimyası verileri göz ardı edilmiș veya sınırlı kalmıștır. Halbuki, kayacı olușturan mineral birliktelikleri ve mineral kimyası, magmanın kökeni ile süreçleri ve yerleșim koșullarılla yakından ilgilidir. Bu anlamda granitoyidi olușturan mineral toplulukları ve mineral kimyasının jenetik açıdan irdelenmesi önem kazanmaktadır. Bu çalıșma kapsamında OAGnden $\mathrm{EMB}$, tüm-kayaç element jeokimya destekli mineral kimyası verileriyle petrolojik açıdan değerlendirilecek ve magma sokulum fizikokimyasal koșullarına bir yaklașımda bulunulacaktır. Mineral kimyası ağırlıklı bu petrolojik çalıșma ile literatüre katkı sağlanacağı ve eklenen her verinin konunun daha iyi anlașılmasına imkan tanıyacağı düșünülmektedir. 


\section{ANALITIK METODLAR}

Granodiyorit ve mikrogranitten 5'er adet, lökogranitten ise 12 adet örneğin tüm-kayaç element jeokimya analizleri Acme Analitik Laboratuvarı (Kanada)'nda yaptırılmıștır (Çizelge 1). Ana, iz ve nadir toprak elementleri (NTE), $\mathrm{LiBO}_{2} / \mathrm{Li}_{2} \mathrm{~B}_{4} \mathrm{O}_{7}$ ile füzyon sonrasında ICP-AES (endüktif eșleșmiș plazma atomik emisyon spektrometresi) ve asitte çözdürme sonrası (\% 5'lik $\mathrm{HNO}_{3}$ ) ICP-MS (endüktif eșleșmiș plazma kütle spektrometresi) kullanılarak ölçülmüștür. Dedeksiyon limitleri ana elementler için $\mathrm{SiO}_{2}, \mathrm{Al}_{2} \mathrm{O}_{3}, \mathrm{MgO}, \mathrm{CaO}, \mathrm{Na}_{2} \mathrm{O}$, $\mathrm{K}_{2} \mathrm{O}, \mathrm{MnO}, \mathrm{TiO}_{2}$ 'de $\% 0.01, \mathrm{Fe}_{2} \mathrm{O}_{3}$ 'te \%0.04, $\mathrm{P}_{2} \mathrm{O}_{5}$ ve $\mathrm{Cr}_{2} \mathrm{O}_{3}$ 'te \%0.001-0.002 ve atește su kaybı (LOI) için $\% 0.10$ 'dır. İz elementler ve NTE dedeksiyon limitleri ise șu șekildedir; V'da 8 ppm, Ba ve Sn'de $1 \mathrm{ppm}$, $\mathrm{Sr}$, Gd ve W'de 0.5 ppm, Nd'da 0.3 ppm, Cs, Hf, Nb, $\mathrm{Rb}, \mathrm{Ta}, \mathrm{U}, \mathrm{Y}, \mathrm{Zr}$, Th, La and Ce'da $0.1 \mathrm{ppm}, \mathrm{Sm}$, Dy, Yb'da 0.05 ppm, Er'de 0.03 ppm, Pr, Eu ve Ho'da 0.02 ppm, Tb, Tm, Lu'da 0.01. Analitik hassasiyet ana elementler için \% 0.05-0.15 olup, iz elementler ve NTE için \%0.5'den \%1.5'e kadar değișmektedir.

Kayaç tiplerini temsil eden örneklerden minerallerin ana ve minör element içerikleri yerinde noktasal ölçüm yapan elektron mikroprob analizi (EPMA) kullanılarak belirlenmiștir. Analiz için gerekli parlatılmıș ince kesitler Potsdam Üniversitesi (Almanya), Yerbilimleri Enstitüsü ve karbon kaplamaları ile analizler CAMECA SX-100 elektron mikroprob kullanılarak Potsdam Yerbilimleri Araștırma Merkezi'nde (GeoForschungsZentrum) gerçekleștirilmiștir. Dalga boyu dağılım modundaki cihaz ile $20 \mathrm{nA}$ bombardıman akıșı ve $15 \mathrm{kV}$ elektron bombardımanı kullanılarak analizler yapılmıștır. Amfibol ve mikaya $5 \mu m^{\prime}$ lik bombardıman çapı ve feldispata ise $10 \mu \mathrm{m}$ uygulanmıștır. Kalibrasyon için çeșitli doğal ve sentetik standardlar kullanılmıștır ( $\mathrm{Fe}$ için $\mathrm{Fe}_{2} \mathrm{O}_{3}$; $\mathrm{Ni}$ için NiO; $\mathrm{Ca}$ ve $\mathrm{Si}$ için diyopsit ve vollastonit; $\mathrm{K}$ ve $\mathrm{Al}$ için ortoklaz ve sanidin; $\mathrm{Ti}$ için rutil; $\mathrm{Cr}$ için $\mathrm{Cr}_{2} \mathrm{O}_{3}$; $\mathrm{Mn}$ için rodokrosit; $\mathrm{Na}$ için albit; $\mathrm{Mg}$ için diyopsit, peric SCOli, MgO; F için fulorit; $\mathrm{Cl}$ için Bora, tugt; $\mathrm{Ba}$ için barit; $\mathrm{P}$ için $\mathrm{YPO}_{4}$ ). Matriks düzeltmeleri CAMECA yazılımında bulunan ve Pouchou ve Pichor (1991) tarafindan hazırlanan PAP programıyla yapılmıștır. EPMA yöntemiyle toplam demir ölçülebildiğinden biyotitlerin $\mathrm{Fe}^{+2}$ ve $\mathrm{Fe}^{+3}$ değerlerini hesaplamak için, Potsdam Üniversitesi, Yerbilimleri Enstitüsü'nde 5 kayaç numunesinden zenginleștirilen saf biyotite $\mathrm{K}_{2} \mathrm{Cr}_{2} \mathrm{O}_{7}$ titrasyon yöntemi (Andrate vd., 2002) uygulanmıștır.

\section{JEOLOJi VE PETROGRAFi}

EMB granitoyidleri öncel çalıșmalarda (Türeli, 1991; Türeli vd., 1993; Göncüoğlu ve Türeli, 1993, 1994; Göncüoğlu vd., 2004; Köksal, 2005) Borucu granodiyorit-monzograniti, Hisarkaya porfiri graniti, Sinandı mikrograniti ve Kalebalta lökograniti olmak üzere dört ana birime ayrımıștır. Toksoy-Köksal vd. (2008, 2009a) ise, bu adlandırmaların sadeleștirilerek granodiyorit, mikrogranit ve lökogranit terimlerinin kullanılmasını, Hisarkaya porfiri granitinin de gerek saha ve gerekse petrolojik özellikleri açısından Borucu granodiyoritine benzerlik göstermesi sebebiyle ayrı bir birim olarak değerlendirilmeyip granodiyorit içinde değerlendilmesini önermiștir. Arazi çalıșmaları kapsamında; Türeli (1991), Türeli vd. (1993), Göncüoğlu ve Türeli $(1993,1994)$ tarafından yapılmıș jeoloji haritası revize edilmiștir (Șekil 1c).

Granodiyorit, bölgede ana granitik fazı olușturmakta olup arazide büyük oval șekilli ve gri tonlu mostralar halinde geniș yayılım göstermektedir. Granodiyorit, faneritik dokusu, yüksek biyotit ve amfibol içeriği (Șekil 2a, b), iri alkali-feldispat kristalleri ile karakterize edilmektedir. İri alkali-feldispat kristalleri büyümeleri sırasında yer yer mikrogranüler amfibollerce kușatımıș ve bu kușatılmadan sonra büyümelerine devam etmiș olup büyümenin en son evresinde yine amfibolce kușatılmıșlardır (Șekil 2b). Granodiyoritte șekilsiz, köșeli veya yarı yuvarlak amfibolce zengin mafik mikrogranüler anklavların (MMA) varlığı dikkat çekmektedir (Șekil 2c). Bölgede, özellikle de kuzeydoğu bölümünde, sadece ayrıșmıș granitik materyalden olușan örtü tabakasının var olduğu gözlemlenmektedir. Bu birimler, Peçenek formasyonu olarak adlandırılan Oligosen-Miyosen örtü tabakasından farklılık göstermesi ve özellikle iri feldispat minerallerinin bulunması nedeniyle, Türeli (1991), Türeli vd. (1993), Göncüoğlu ve Türeli $(1993,1994)$ tarafından kabul edildiği gibi haritada granitik toprak olarak adlandırımıștır (Șekil 1c). Granodiyorit, Sinandı ve Yanyurt köyleri civarında mikrogranitle dokanak halindedir. Ancak bu alanlardaki kesme ilișkisi net olarak belirlenememiștir. Bölgenin kuzeyinde Hisarkaya yöresinde ve güneydoğusunda, Kalebalta yöresinde ise lökogranite ait dayklarca kesilmektedir.

Mikrogranit, bölgenin kuzeybatısında Sinandı köyü civarında ve kuzey-kuzeydoğusunda, Yanyurt civarında ve doğu-güneydoğusunda yüzeylenmektedir (Șekil 1c). Mikrogranit mikrogranüler yapısı ve koyu gri rengi ile arazide ayırtlanmakta olup, yüksek biyotit 
Çizelge 1. Ekecikdağ granitoyidleri tüm kayaç jeokimya verileri (M: Mikrogranit; G: Granodiyorit; L: Lökogranit). Table 1. Whole-rock geochemical data for the Ekecikdağ granitoids (M: Microgranite; G: Granodiorite; L: Leucogranite).

\begin{tabular}{|c|c|c|c|c|c|c|c|c|c|c|c|c|c|}
\hline & EK-1 & EK-4 & EK-6 & EK-8 & EK-25 & EK-5 & EK-10 & EK-14 & EK-16 & EK-17 & EK-18 & EK-21 & EK-52 \\
\hline $\begin{array}{c}\text { Granitoyid } \\
(\%)\end{array}$ & $\mathbf{M}$ & $\mathbf{M}$ & $\mathbf{M}$ & $\mathbf{M}$ & $\mathbf{M}$ & $\mathbf{G}$ & $\mathbf{G}$ & $\mathbf{G}$ & $\mathbf{G}$ & $\mathbf{G}$ & $\mathbf{G}$ & $\mathbf{G}$ & $\mathbf{G}$ \\
\hline $\mathrm{SiO}_{2}$ & 70.6 & 69.9 & 71.4 & 71.0 & 70.0 & 69.2 & 68.8 & 69.1 & 69.0 & 68.7 & 69.0 & 71.1 & 72.1 \\
\hline $\mathrm{TiO}_{2}$ & 0.36 & 0.40 & 0.34 & 0.37 & 0.42 & 0.27 & 0.29 & 0.36 & 0.31 & 0.36 & 0.32 & 0.31 & 0.22 \\
\hline $\mathrm{Al}_{2} \mathrm{O}_{3}$ & 14.8 & 15.1 & 14.8 & 15.1 & 14.9 & 15.0 & 15.1 & 14.9 & 14.9 & 14.4 & 14.8 & 13.7 & 14.2 \\
\hline $\mathrm{FeO}_{(\mathrm{t})}$ & 2.68 & 3.14 & 2.83 & 3.05 & 3.33 & 3.41 & 3.64 & 3.82 & 3.32 & 3.79 & 3.64 & 3.37 & 2.53 \\
\hline MnO & 0.06 & 0.06 & 0.06 & 0.06 & 0.07 & 0.06 & 0.07 & 0.07 & 0.06 & 0.07 & 0.06 & 0.06 & 0.06 \\
\hline MgO & 0.71 & 0.88 & 0.65 & 0.76 & 0.80 & 1.00 & 1.10 & 1.14 & 0.98 & 1.09 & 1.06 & 0.98 & 0.69 \\
\hline $\mathrm{CaO}$ & 2.58 & 2.62 & 2.13 & 2.51 & 2.81 & 2.93 & 2.94 & 3.46 & 2.95 & 2.98 & 3.03 & 2.78 & 2.15 \\
\hline $\mathrm{Na} 2 \mathrm{O}$ & 2.66 & 2.76 & 2.72 & 2.74 & 2.80 & 2.92 & 2.92 & 2.76 & 2.81 & 2.70 & 2.87 & 2.43 & 2.80 \\
\hline K2O & 4.01 & 3.95 & 4.17 & 3.56 & 3.78 & 4.20 & 4.06 & 2.99 & 4.67 & 3.18 & 4.06 & 3.18 & 4.58 \\
\hline $\mathbf{P}_{2} \mathbf{O}_{5}$ & 0.12 & 0.15 & 0.11 & 0.12 & 0.15 & 0.06 & 0.07 & 0.06 & 0.08 & 0.06 & 0.09 & 0.05 & 0.06 \\
\hline $\mathrm{Cr}_{2} \mathrm{O}_{3}$ & 0.02 & 0.02 & 0.02 & 0.03 & 0.02 & 0.03 & 0.02 & 0.01 & 0.03 & 0.01 & 0.05 & 0.01 & 0.02 \\
\hline LOI* $^{*}$ & 1.20 & 0.90 & 0.60 & 0.50 & 0.80 & 0.80 & 0.80 & 0.62 & 0.80 & 0.40 & 0.90 & 0.49 & 0.40 \\
\hline Toplam & 99.8 & 99.9 & 99.8 & 99.8 & 99.9 & 99.9 & 99.8 & 99.3 & 99.9 & 97.7 & 99.9 & 98.5 & 99.8 \\
\hline \multicolumn{14}{|l|}{ (ppm) } \\
\hline $\mathbf{R b}$ & 126 & 148 & 152 & 133 & 127 & 164 & 152 & 153 & 163 & 169 & 163 & 157 & 227 \\
\hline $\mathrm{Sr}$ & 217 & 237 & 191 & 226 & 219 & 143 & 142 & 145 & 145 & 128 & 142 & 121 & 122 \\
\hline $\mathrm{Nb}$ & 12 & 13 & 12 & 13 & 15 & 7 & 7 & 9 & 9 & 10 & 10 & 9 & 10 \\
\hline La & 31.0 & 35.7 & 30.6 & 35.2 & 36.6 & 21.0 & 30.4 & 19.9 & 61.1 & 25.8 & 38.1 & 21.6 & 26.5 \\
\hline $\mathrm{Ce}$ & 60.6 & 68.2 & 58.6 & 67.7 & 72.0 & 37.9 & 54.6 & 39.8 & 100.6 & 49.4 & 65.2 & 45.1 & 48.2 \\
\hline Pr & 7.0 & 7.9 & 6.9 & 7.8 & 8.2 & 4.0 & 5.6 & 4.5 & 10.4 & 5.3 & 7.1 & 4.7 & 5.6 \\
\hline Nd & 26.1 & 30.3 & 25.4 & 29.4 & 31.4 & 13.7 & 19.3 & 15.9 & 31.3 & 18.7 & 23.8 & 16.9 & 19.8 \\
\hline Sm & 5.0 & 5.5 & 5.1 & 5.5 & 6.1 & 2.6 & 3.1 & 3.1 & 4.3 & 3.5 & 3.8 & 3.2 & 3.6 \\
\hline Eu & 1.07 & 1.32 & 0.99 & 1.13 & 1.22 & 0.61 & 0.63 & 0.73 & 0.69 & 0.78 & 0.62 & 0.76 & 0.59 \\
\hline Gd & 4.37 & 4.79 & 4.22 & 4.76 & 5.76 & 2.42 & 2.74 & 3.61 & 3.11 & 3.83 & 3.40 & 3.47 & 3.27 \\
\hline Tb & 0.70 & 0.69 & 0.64 & 0.73 & 0.99 & 0.41 & 0.45 & 0.53 & 0.44 & 0.57 & 0.47 & 0.56 & 0.55 \\
\hline Dy & 3.68 & 3.77 & 3.48 & 4.00 & 5.43 & 2.61 & 2.72 & 3.20 & 2.64 & 3.29 & 2.95 & 3.28 & 3.27 \\
\hline Ho & 0.68 & 0.66 & 0.64 & 0.74 & 1.09 & 0.54 & 0.54 & 0.69 & 0.53 & 0.68 & 0.61 & 0.64 & 0.69 \\
\hline Er & 1.89 & 1.87 & 1.68 & 2.01 & 3.09 & 1.57 & 1.63 & 2.14 & 1.52 & 2.09 & 1.88 & 2.07 & 2.09 \\
\hline $\mathrm{Tm}$ & 0.28 & 0.27 & 0.27 & 0.31 & 0.48 & 0.25 & 0.26 & 0.32 & 0.26 & 0.33 & 0.28 & 0.33 & 0.34 \\
\hline $\mathrm{Yb}$ & 1.78 & 1.80 & 1.69 & 1.96 & 2.88 & 1.74 & 1.75 & 2.10 & 1.70 & 2.18 & 1.90 & 2.14 & 2.32 \\
\hline Lu & 0.26 & 0.27 & 0.24 & 0.30 & 0.42 & 0.27 & 0.25 & 0.34 & 0.26 & 0.34 & 0.29 & 0.37 & 0.36 \\
\hline $\mathbf{Y}$ & 20 & 20 & 18 & 21 & 32 & 15 & 16 & 17 & 15 & 19 & 17 & 19 & 21 \\
\hline Cs & 4.6 & 38.2 & 8.1 & 5.5 & 9.2 & 6.6 & 5.0 & 7.0 & 6.1 & 6.6 & 7.3 & 7.4 & 11.0 \\
\hline
\end{tabular}


Çizelge 1. Devam ediyor.

Table 1. Contiuned.

\begin{tabular}{|c|c|c|c|c|c|c|c|c|c|c|c|c|c|}
\hline & EK-1 & EK-4 & EK-6 & EK-8 & EK-25 & EK-5 & EK-10 & EK-14 & EK-16 & EK-17 & EK-18 & EK-21 & EK-52 \\
\hline $\begin{array}{l}\text { Granitoyid } \\
\text { (ppm) }\end{array}$ & M & M & M & M & M & G & $\mathbf{G}$ & $\mathbf{G}$ & $\mathbf{G}$ & $\mathbf{G}$ & $\mathbf{G}$ & $\mathbf{G}$ & $\mathbf{G}$ \\
\hline Ta & 0.9 & 0.9 & 1.0 & 1.1 & 1.1 & 0.9 & 0.7 & 1.0 & 0.8 & 1.03 & 0.9 & 1.16 & 1.2 \\
\hline Sc & 7.0 & 7.0 & 7.0 & 7.0 & 9.0 & 6.0 & 8.0 & 6.8 & 6.0 & 6.4 & 7.0 & 5.7 & 4.0 \\
\hline $\mathrm{Pb}$ & 1.6 & 6.3 & 3.8 & 2.6 & 3.0 & 3.4 & 3.7 & 25.2 & 5.1 & 25.7 & 8.2 & 27.8 & 9.8 \\
\hline $\mathbf{U}$ & 2.2 & 2.7 & 2.6 & 2.8 & 2.3 & 5.0 & 4.3 & 4.1 & 6.3 & 5.0 & 4.8 & 6.78 & 8.3 \\
\hline Th & 10.9 & 13.5 & 12.5 & 13.8 & 10.4 & 13.4 & 21.0 & 14.1 & 27.8 & 24.3 & 21.2 & 20.7 & 20.8 \\
\hline $\mathrm{Ni}$ & 8.6 & 5.8 & 5.7 & 8.8 & 8.3 & 7.3 & 13 & 4.6 & 9.6 & 4.3 & 11.7 & 3.2 & 4.4 \\
\hline $\mathrm{Cu}$ & 2.3 & 2.3 & 3.1 & 2.7 & 1.7 & 3.2 & 2.9 & 9.6 & 5.1 & 4.0 & 27.7 & 1.5 & 2.3 \\
\hline Ga & 15.5 & 16.2 & 15.2 & 16.3 & 16.4 & 13.6 & 13.6 & 14.7 & 14.0 & 14.5 & 14.7 & 13.8 & 14.7 \\
\hline Mo & 1.5 & 2 & 2.1 & 2.9 & 1.9 & 3.2 & 1.8 & 0.31 & 3.3 & n.d. & 5.4 & n.d. & 1.8 \\
\hline $\mathrm{Ba}$ & 717 & 901 & 709 & 765 & 799 & 573 & 589 & 473 & 594 & 384 & 445 & 369 & 462 \\
\hline v & 17 & 23 & 18 & 19 & 24 & 40 & 43 & 21 & 37 & 13 & 40 & 14 & 25 \\
\hline $\mathrm{Zr}$ & 151 & 179 & 144 & 177 & 177 & 106 & 113 & 40 & 135 & 31.6 & 139 & 39 & 105 \\
\hline$Z n$ & 43 & 49 & 52 & 47 & 56 & 32 & 33 & 36 & 35 & 37 & 38 & 32 & 37 \\
\hline \multirow[t]{2}{*}{$\mathrm{Hf}$} & 4.4 & 5.1 & 4.4 & 5.3 & 5.0 & 3.2 & 3.6 & 1.9 & 4.0 & 1.5 & 3.9 & 1.8 & 3.5 \\
\hline & EK-19 & EK-20 & EK-22 & EK-23 & EK-24 & EK-26 & EK-27 & EK-28 & EK-31 & EK-32 & EK-53 & EK-57 & \\
\hline $\begin{array}{c}\text { Granitoyid } \\
(\%)\end{array}$ & $\mathbf{L}$ & $\mathbf{L}$ & $\mathbf{L}$ & $\mathbf{L}$ & $\mathbf{L}$ & $\mathbf{L}$ & $\mathbf{L}$ & $\mathbf{L}$ & $\mathbf{L}$ & $\mathbf{L}$ & $\mathbf{L}$ & $\mathbf{L}$ & \\
\hline $\mathrm{SiO}_{2}$ & 77.0 & 77.1 & 76.0 & 76.2 & 76.4 & 77.7 & 76.1 & 77.0 & 75.4 & 76.5 & 76.2 & 76.6 & \\
\hline $\mathrm{TiO}_{2}$ & 0.05 & 0.05 & 0.04 & 0.05 & 0.04 & 0.07 & 0.03 & 0.02 & 0.08 & 0.07 & 0.03 & 0.03 & \\
\hline $\mathrm{Al}_{2} \mathrm{O}_{3}$ & 12.3 & 12.6 & 12.8 & 12.6 & 12.7 & 12.2 & 12.9 & 12.5 & 12.9 & 12.7 & 12.8 & 12.6 & \\
\hline $\mathrm{FeO}_{(\mathrm{t})}$ & 1.05 & 0.92 & 0.94 & 0.98 & 0.97 & 1.21 & 0.88 & 1.07 & 1.33 & 1.08 & 0.75 & 0.91 & \\
\hline MnO & 0.03 & 0.02 & 0.01 & 0.02 & 0.01 & 0.02 & 0.01 & 0.06 & 0.06 & 0.06 & 0.01 & 0.01 & \\
\hline MgO & 0.04 & 0.04 & 0.05 & 0.04 & 0.06 & 0.04 & 0.03 & 0.03 & 0.14 & 0.12 & 0.10 & 0.10 & \\
\hline $\mathrm{CaO}$ & 0.60 & 0.73 & 1.05 & 0.56 & 1.07 & 0.64 & 0.83 & 0.74 & 0.74 & 0.78 & 0.84 & 1.08 & \\
\hline $\mathrm{Na2O}$ & 3.45 & 3.44 & 2.81 & 3.48 & 2.88 & 3.25 & 3.31 & 3.57 & 3.41 & 3.44 & 2.50 & 2.99 & \\
\hline K2O & 4.64 & 4.70 & 5.25 & 4.98 & 5.10 & 4.94 & 5.10 & 4.66 & 5.08 & 4.90 & 6.07 & 4.90 & \\
\hline $\mathrm{P}_{2} \mathrm{O}_{5}$ & 0.00 & 0.01 & 0.02 & 0.02 & 0.03 & 0.01 & 0.02 & 0.02 & 0.02 & 0.03 & 0.01 & 0.01 & \\
\hline $\mathrm{Cr}_{2} \mathrm{O}_{3}$ & 0.05 & 0.02 & 0.02 & 0.04 & 0.05 & 0.02 & 0.02 & 0.03 & 0.04 & 0.02 & 0.05 & 0.04 & \\
\hline LOI* $^{*}$ & 0.80 & 0.40 & 1.00 & 0.90 & 0.60 & 0.20 & 0.70 & 0.20 & 0.70 & 0.30 & 0.60 & 0.70 & \\
\hline Toplam & 100.0 & 100.0 & 100.0 & 99.9 & 99.9 & 99.9 & 99.9 & 99.9 & 99.9 & 100.0 & 100.0 & 100.0 & \\
\hline \multicolumn{14}{|l|}{ (ppm) } \\
\hline $\mathbf{R b}$ & 376 & 339 & 209 & 444 & 198 & 398 & 263 & 305 & 400 & 385 & 234 & 209 & \\
\hline $\mathrm{Sr}$ & 6 & 10 & 24 & 9 & 26 & 7 & 20 & 5 & 29 & 28 & 35 & 30 & \\
\hline $\mathrm{Nb}$ & 13 & 20 & 14 & 40 & 6 & 34 & 10 & 5 & 22 & 22 & 2 & 10 & \\
\hline
\end{tabular}


Çizelge 1. Devam ediyor.

Table 1. Contiuned.

\begin{tabular}{|c|c|c|c|c|c|c|c|c|c|c|c|c|}
\hline & EK-19 & EK-20 & EK-22 & EK-23 & EK-24 & EK-26 & EK-27 & EK-28 & EK-31 & EK-32 & EK-53 & EK-57 \\
\hline $\begin{array}{c}\text { Granitoyid } \\
\text { (ppm) }\end{array}$ & $\mathbf{L}$ & $\mathbf{L}$ & $\mathbf{L}$ & $\mathbf{L}$ & $\mathbf{L}$ & L & $\mathbf{L}$ & $\mathbf{L}$ & $\mathbf{L}$ & L & $\mathbf{L}$ & $\mathbf{L}$ \\
\hline La & 8.3 & 8.8 & 8.8 & 11.5 & 7.7 & 11.5 & 13.2 & 8.5 & 19.3 & 18.6 & 17.4 & 17.1 \\
\hline $\mathrm{Ce}$ & 23.3 & 19.6 & 22.1 & 27.0 & 24.6 & 25.4 & 26.8 & 17.9 & 38.9 & 37.5 & 39.1 & 32.1 \\
\hline $\mathrm{Pr}$ & 2.2 & 2.4 & 2.4 & 3.4 & 2.0 & 3.0 & 2.9 & 2.2 & 4.2 & 4.1 & 3.9 & 3.9 \\
\hline Nd & 8.2 & 8.9 & 8.4 & 12.8 & 7.0 & 10.6 & 9.7 & 7.7 & 14.9 & 14.5 & 13.0 & 13.0 \\
\hline Sm & 2.0 & 2.2 & 1.9 & 3.8 & 1.5 & 2.9 & 2.4 & 1.8 & 3.9 & 3.5 & 2.4 & 3.1 \\
\hline Eu & 0.11 & 0.16 & 0.17 & 0.11 & 0.17 & 0.09 & 0.12 & 0.06 & 0.16 & 0.17 & 0.23 & 0.14 \\
\hline Gd & 1.86 & 2.40 & 2.04 & 4.37 & 1.37 & 3.09 & 2.63 & 1.96 & 4.51 & 3.91 & 1.87 & 3.28 \\
\hline Tb & 0.40 & 0.49 & 0.43 & 1.00 & 0.25 & 0.67 & 0.61 & 0.42 & 1.00 & 0.83 & 0.30 & 0.64 \\
\hline Dy & 2.40 & 3.08 & 2.63 & 6.44 & 1.52 & 4.25 & 4.27 & 2.96 & 6.34 & 5.15 & 1.75 & 4.28 \\
\hline Ho & 0.53 & 0.71 & 0.66 & 1.50 & 0.35 & 0.94 & 1.04 & 0.78 & 1.49 & 1.14 & 0.37 & 0.93 \\
\hline Er & 1.73 & 2.28 & 2.15 & 4.95 & 1.16 & 2.85 & 3.59 & 2.69 & 4.53 & 3.49 & 1.16 & 3.06 \\
\hline $\mathrm{Tm}$ & 0.31 & 0.41 & 0.40 & 0.90 & 0.23 & 0.50 & 0.70 & 0.52 & 0.76 & 0.60 & 0.24 & 0.54 \\
\hline Yb & 2.28 & 2.85 & 2.87 & 6.43 & 1.63 & 3.26 & 5.10 & 4.04 & 5.04 & 4.04 & 1.56 & 3.76 \\
\hline Lu & 0.34 & 0.46 & 0.44 & 1.04 & 0.28 & 0.49 & 0.83 & 0.67 & 0.74 & 0.62 & 0.26 & 0.63 \\
\hline $\mathbf{Y}$ & 16 & 21 & 18 & 47 & 11 & 26 & 35 & 26 & 47 & 36 & 11 & 30 \\
\hline Cs & 17.4 & 7.9 & 5.1 & 14.0 & 4.6 & 5.1 & 4.2 & 5.7 & 7.7 & 6.8 & 5.0 & 3.0 \\
\hline Ta & 2.3 & 2.7 & 3.7 & 5.3 & 1.3 & 3.7 & 2.8 & 1.0 & 3.1 & 3.6 & 0.6 & 2.9 \\
\hline Sc & 0.9 & 0.9 & 0.9 & 2.0 & 0.9 & 2.0 & 0.9 & 0.9 & 3.0 & 2.0 & 0.9 & 2.0 \\
\hline $\mathrm{Pb}$ & 8.8 & 8.8 & 4.8 & 12.5 & 6.7 & 15.4 & 9.2 & 7.9 & 7.1 & 5.4 & 9.2 & 6.4 \\
\hline $\mathbf{U}$ & 3.2 & 5.5 & 10.1 & 18.0 & 5.5 & 5.1 & 7.0 & 5.6 & 11.7 & 16.0 & 6.5 & 5.2 \\
\hline Th & 18.1 & 32.9 & 26.8 & 34.8 & 30.9 & 32.8 & 28.8 & 45.2 & 33.9 & 34.3 & 33.4 & 25.7 \\
\hline $\mathrm{Ni}$ & 7.2 & 5.2 & 4.3 & 4.8 & 8.4 & 3.1 & 5.6 & 6.4 & 5.8 & 6.7 & 6.1 & 8.2 \\
\hline $\mathrm{Cu}$ & 3.3 & 1.8 & 13.5 & 3.2 & 51.8 & 2.4 & 21.7 & 3.1 & 2.6 & 1.3 & 3 & 3.8 \\
\hline Ga & 10.7 & 11.7 & 11.5 & 13.8 & 11.4 & 12.5 & 12.4 & 12.5 & 12.8 & 12.9 & 10.9 & 12.3 \\
\hline Mo & 5.4 & 2.3 & 1.9 & 4.2 & 4.3 & 2.3 & 1.9 & 2.6 & 4.4 & 1.7 & 4.5 & 4.9 \\
\hline $\mathrm{Ba}$ & 6 & 5 & 13 & 21 & 16 & 13 & 17 & 9 & 128 & 109 & 44 & 49 \\
\hline $\mathbf{v}$ & $<8$ & $<8$ & $<8$ & $<8$ & $<8$ & $<8$ & $<8$ & $<8$ & $<8$ & $<8$ & $<8$ & $<8$ \\
\hline $\mathrm{Zr}$ & 28 & 47 & 24 & 82 & 43 & 68 & 69 & 85 & 75 & 82 & 61 & 57 \\
\hline $\mathrm{Zn}$ & 7 & 5 & 8 & 7 & 8 & 7 & 11 & 4 & 12 & 13 & 6 & 5 \\
\hline Hf & 1.5 & 2.3 & 1.5 & 4.4 & 2.3 & 3.0 & 3.9 & 4.5 & 3.0 & 3.2 & 2.8 & 3.2 \\
\hline
\end{tabular}

* atește su kaybı 

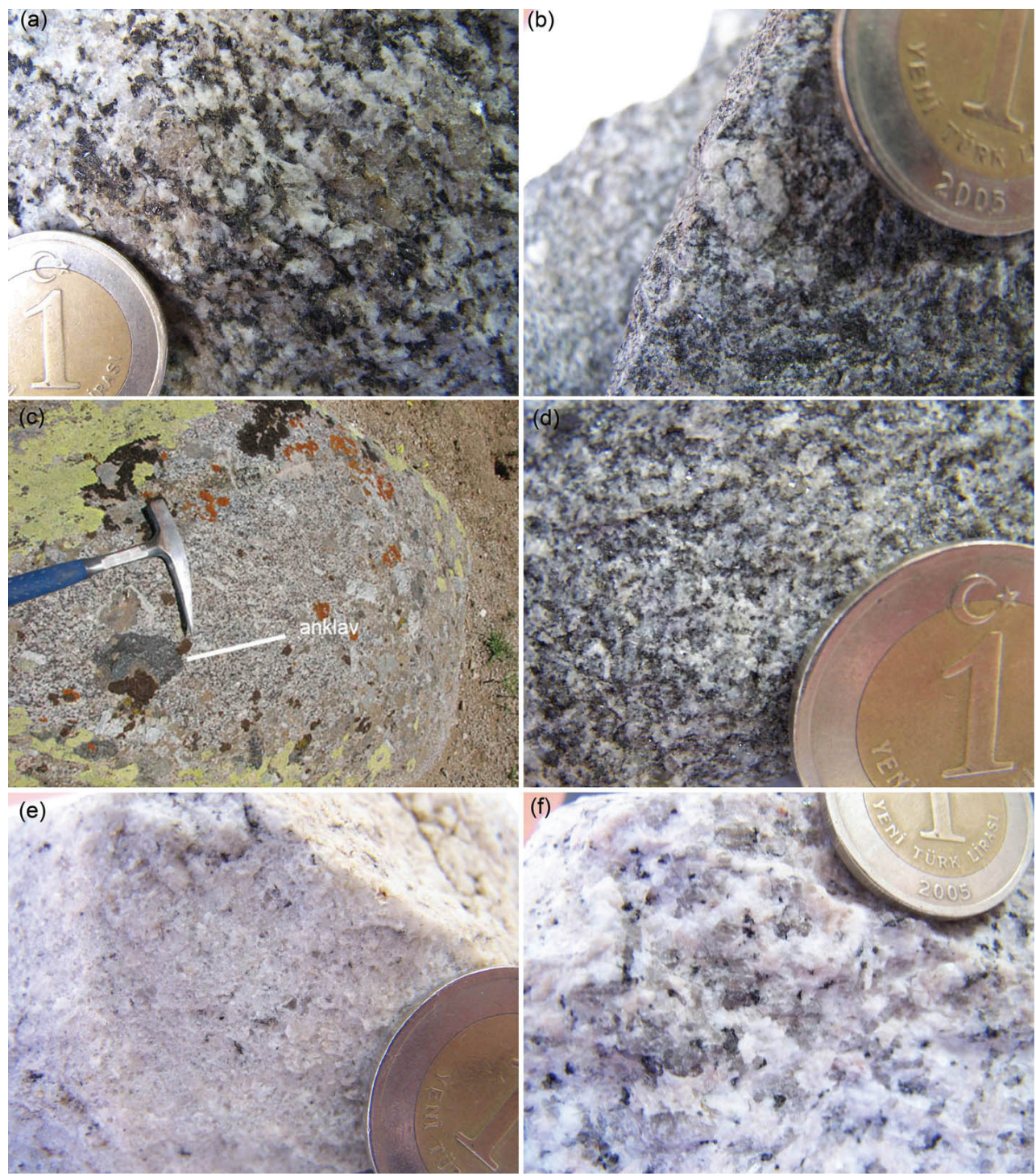

Șekil 2. (a) Granodiyoritin yakın görünümü, (b) granodiyoritte hibritleșmenin göstergesi alkali feldispatı çevreleyen mikrogranüler amfibol ve onu da çevreleyerek büyüyen alkali-feldispat, (c) granodiyoritte hibritleșmenin göstergesi mafik mikrogranüler anklav, (d) mikrogranitin yakın görünümü, (e-f) lökogranitin yakın görünümü.

Figure 2. (a) Close view of granodiorite, (b) alkali-feldspar mantled by microgranular amphibole and remantling alkali-feldspar that reveal hybridization in granodiorite, (c) microgranular mafic enclave showing hybridic character of granodiorite, (d) close view of microgranite, (e-f) close view of leucogranite.

içeriği ile göze çarpmaktadır (Șekil 2d). Granodiyoritle olan ilișkisi arazide net olarak tespit edilemeyen mikrogranit lökogranit tarafından kesilmektedir.

Lökogranit ise bölgenin doğu ve güneydoğu bölümünde büyük mostra șeklinde, diğer bölümlerde ise granodiyorit ile mikrogranite ve yer yer gabroyik kayaçlara sokulum yaparken rastlanmaktadır (Șekil 1c). Özellikle kuzey bölümde granodiyorite sokulum yapan dayk serileri șeklinde gözlenmektedir (Șekil 1c).
Lökogranit bölgede pembemsi beyaz rengi, orta-eșit taneli yapısı ve mafik minerallerinin azlığı ile ayırtlanmaktadır (Șekil 2e, f). İncelenen granitoyid örneklerinin büyük bir bölümünde el örneklerinde kloritleșme, kaolinleșme ve serisitleșme ürünü bașkalașım mineralleri gözlenmektedir.

Granitik kayaçlar ve yöredeki ofiyolitik ve metamorfik kayaçlar, nehir yatağı ve/veya gölsel ortamı karakterize eden, yatay tabakalı ince taneli killi-tüflü, yer yer 
kuvars, jips, opal ve biyotit mineralleri içeren Oligosen-Miyosen yașlı Peçenek formasyonu ile uyumsuz olarak örtülmektedir.

Ekecikdağ yöresindeki granitik kayaçlar genel olarak değerlendirildiğinde; granodiyoritte yaygın hornblend mineralinin varlığı, mikrogranit ve lökogranitte ise birincil biyotit-muskovit birlikteliği dikkat çekmektedir. Bu kayaçların petrografik özellikleri kısaca așağıda sunulmaktadır.

Granodiyorit; hornblend, biyotit, plajiyoklaz, ortoklaz ve kuvars minerallerini içermektedir (Șekil 3a). Bu kaya tipinde zirkon, titanit, allanit, apatit ve manyetit aksesuar olarak belirlenen fazlardır. Yarı-özșekilli ve șekilsiz kristallerden olușan granodiyorit orta boylu mineralleriyle faneritik ve granitik doku ve yer yer iri alkali-feldispat kristalleriyle porfirik doku göstermektedir. Alkali-feldispatlar genellikle karlsbad ikizlenmesi ile pertitik dokuya sahip iken plajiyoklazlar genellikle zonludur. \%9-13 civarında bulunan biyotit sarı-yeșil-kahverenklidir. Kayaç içerisinde bulunan hornblend minerallerinin yanısıra, hornlendce zengin ve az miktarda plajiyoklaz içeren MMA da bu granitoyidde oldukça yaygındır (Șekil 3b).

Mikrogranitte kuvars, ortoklaz, mikroklin, plajiyoklaz, biyotit ile muskovit ana minerallerdir (Șekil 3c). Kayaçta belirlenen aksesuar mineraller ise zirkon, apatit ve manyetittir. Yarı-șekilli ve șekilsiz kristallerden olușan mikrogranit mikrofaneritik doku ile karakterize edilir. Ayrıca mikrografik ve mirmetikitik doku da gözlenmektedir. Kuvarslar özșekilsiz olup, granitik doku göstermektedir (Șekil 3d). Ortoklazlar genellikle karlsbad ikizlenmesi ile pertitik dokuya sahiptirler. Kayaçta yaygın albitik ikizlenmeli plajiyoklazların yanısıra zonlu plajiyoklazlar da bulunmaktadır. Biyotitler yeșil, kırmızı-kahverengi olup sarı-yeșil veya kahverengi-yeșil pleokroizma göstermektedirler. Biyotit - birincil muskovit birlikteliğinin (Șekil 3c) yanısıra ikincil muskovit olușumları da incelenen kesitlerde saptanmıștır. Bunun yanısıra, bazı biyotit kristallerinde kloritleșme görülmektedir.

Lökogranitte ise kuvars, ortoklaz, plajiyoklaz, biyotit ana mineraller olup muskovit, apatit, zirkon ve manyetit aksesuar minerallerdir (Șekil 3e,f). Lökogranit eșit boyutlu kuvars, ortoklaz ve az miktarda biyotit ve aksesuar muskovit içeriği ile lökokratiktir. Granitik doku ile yer yer mikrografik doku göstermektedir (Șekil 3f). Plajiyoklaz genelde albit içerikli olup, bazı kesitlerde özșeklini korumuș olarak gözlenmektedir. Muskovit biyotitle beraber birincil olarak bulunduğu gibi, yer yer ikincil olarak da bulunmaktadır.

\section{TÜM-KAYAÇ ELEMENT JEOKIMYASI}

Ekecikdağ granitoyidlerinde yapılan öncel çalıșmalarda nadir toprak elementlerini (NTE) de içeren tam bir veri seti bulunmadığından 22 adet örneğin tümkayaç element analizi yaptıııııștır (Çizelge 1).

Kayaçların bașkalașımdan etkilenme düzeyini belirlemek üzere zirkonyuma karșillk ana ve iz element grafikleri çizilmiștir (Șekil 4). Genel olarak düzenli dağılım gösteren bu grafiklere göre bașkalașımdan etkilenme minimum olup ana ve iz elementlerin tümü jeokimyasal değerlendirmelerde kullanıma uygundur.

Granitoyid örneklerinin tamamı $\mathrm{SiO}_{2}$ 'ye karșılık $\mathrm{Na}_{2} \mathrm{O}+\mathrm{K}_{2} \mathrm{O}$ grafiğinde (Irvine ve Baragar, 1971) subalkalen alana düșmektedir (Șekil $5 \mathrm{a}$ ). $\mathrm{SiO}_{2}-\mathrm{K}_{2} \mathrm{O}$ grafiğinde (Peccerillo ve Taylor, 1976) ise örnekler yüksek potasyumlu kalk-alkalen seri içinde yer almaktadır (Șekil 5b). Maniar ve Piccoli (1989)'nin Shand (1943) sınıflamasında belirlediği sınırlara göre granodiyorit $\mathrm{A} / \mathrm{CNK}[\mathrm{Al} /(\mathrm{Ca}+\mathrm{Na}+\mathrm{K})]<1.1$ değerleri ile metalüminalıdan zayıf peralüminalıya geçiș göstermektedir (Șekil 5c). Buna karșın mikrogranit örnekleri bir adet zayıf peralüminalı örnek dıșında $A / C N K>1.1$ oranıyla peralüminalı karakterdedir. Lökogranit ise 1.0-1.1 arasındaki $A / C N K$ değerleriyle zayıf peralüminyum özellik sunmaktadır.

Zirkonyuma karșı çizdirilen iz element grafiklerinde 24-85 ppm arasında değișen düșük $\mathrm{Zr}$ değerleriyle lökogranit diğerlerinden (106-177 ppm) kolayca ayırtlanmaktadır (Șekil 4). Grafiklere bakıldığında kayaçların genel bir eğilim olușturduğu düșünülmekle birlikte detay incelemeler, farklı eğilimlere sahip ve birbirleriyle jenetik ilișkileri belli-belirsiz olan örnek topluluklarını ortaya çıkarmaktadır.

68.8-77.7 \% arasında değișen $\mathrm{SiO}_{2}$ 'ye karșılık çizdirilen ana element değișim diyagramlarında yine lökogranit örnekleri yüksek $\mathrm{SiO}_{2}$ (75.4-77.5\%) ve düșük $\mathrm{TiO}_{2}, \mathrm{Al}_{2} \mathrm{O}_{3}, \mathrm{MgO}, \mathrm{CaO}, \mathrm{P}_{2} \mathrm{O}_{5}$ ve $\mathrm{FeO}_{(t)}(\%)$ içerikleriyle diğer örneklerden bariz bir șekilde ayrılmaktadır (Șekil 6). $\mathrm{MgO}, \mathrm{CaO}$ ve $\mathrm{FeO}_{(t)}{ }^{\prime}$ in $\mathrm{SiO}_{2}$ 'ye karșı davranıșlarına bakıldığında, Zr'a karșı iz elementlerin değișimlerinin ișaret ettiği gibi granodiyorit ve mikrogranit arasında bir fraksiyonlașma ilișkisi olduğu düșünülebilir (Șekil 6). Ancak $\mathrm{TiO}_{2}$ ve $\mathrm{P}_{2} \mathrm{O}_{5}$ 'nin $\mathrm{SiO}_{2}$ 'ye karșı davranıșları incelendiğinde mikrogranit ve granodiyoritin birbirlerinden farklı eğilimler gösterdikleri saptanmıștır (Șekil 6).

Bu özellikler iz elementlerin $\mathrm{SiO}_{2}$ 'ye karșı davranıșlarında da gözlenmektedir (Șekil 6). Lökogranit yüksek $\mathrm{SiO}_{2}$ 'ye içeriğine karșlık düșük $\mathrm{Sr}, \mathrm{Ba}, \mathrm{Zr}$ ve Nd içe- 

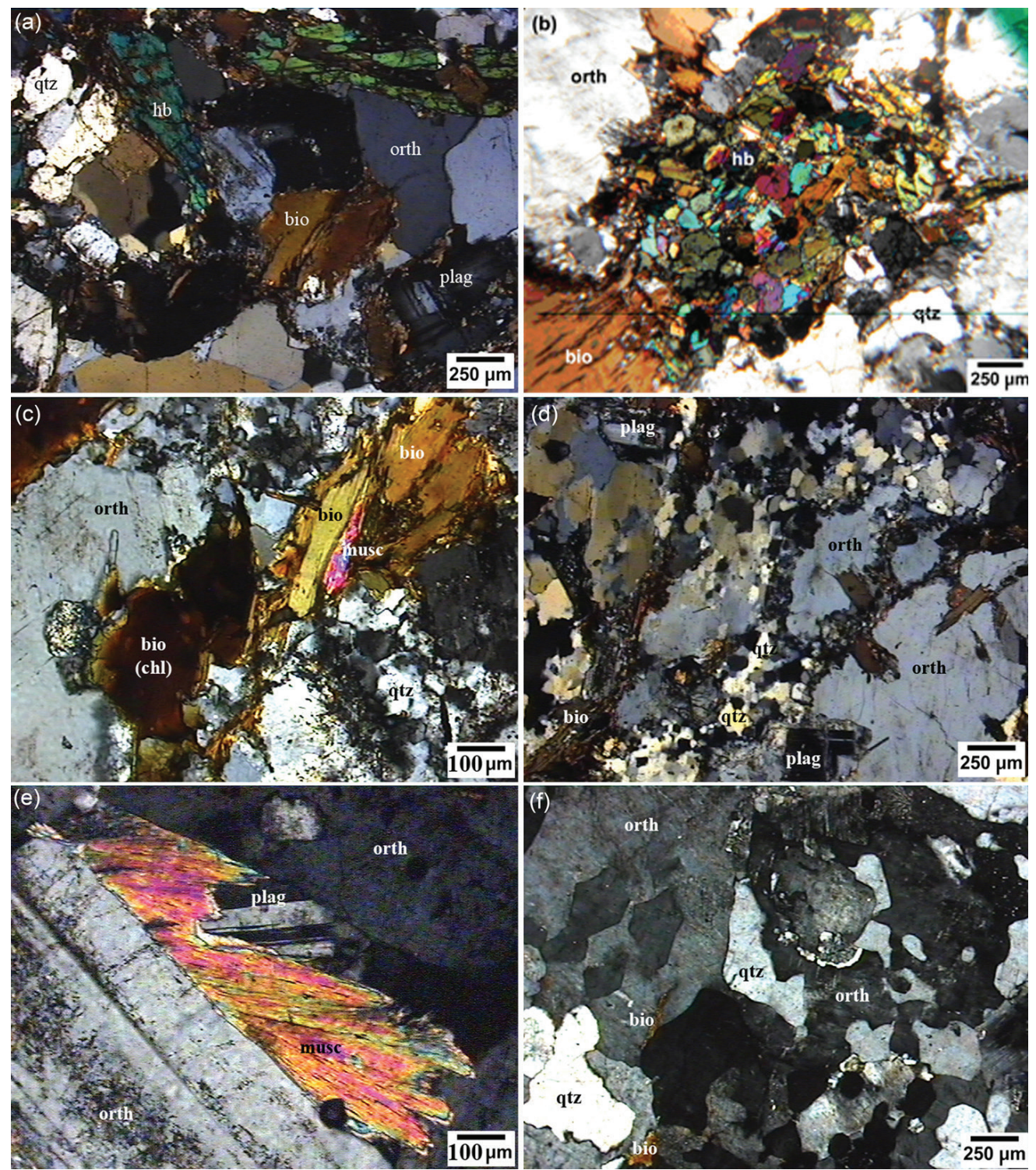

Șekil 3. (a) Granodiyoritten genel petrografik görünüm, (b) granidiyoritteki mikrogranüler amfibolce zengin anklav, (c) mikrogranitde iki mika (biyotit-muskovit) birlikteliğini gösteren petrografik görünüm, (d) mikrogranitin son faz mikro-kuvarsların orta tanelerin arasında dağılımı, grafik dokulu büyümeler ve biyotit, (e) lökogranitte birincil muskovit, (f) lökogranitte biyotit ve grafik dokulu kuvars büyümeleri (hb: hornblend, plag: plajiyoklaz, orth: ortoklaz, qtz: kuvars, bio: biyotit, musc: muskovit).

Figure 3. (a) General petrographical view of granodiorite, (b) microgranular amphibol enriched enclave in granodiorite, (c) two mica (biotite-muscovite) assemblage in microgranite, (d) distribution of micro-quartz crystals among medium grained material in microgranite, (e) primary muscovite in leucogranite, (f) biotite and graphically growth quartz in leucogranite (hb: hornblende, plag: plagioclase, orth: orthoclase, qtz: quartz, bio: biotite, musc: muscovite).

riğiyle diğer kayaçlardan ayrılırken, $\mathrm{Rb}, \mathrm{Th}, \mathrm{Y}, \mathrm{Pb}$ ve $\mathrm{Nb}$ elementlerinde geniș bir dağılım göstermektedir. Mikrogranit ve granodiyorit örneklerinin iz elementleri incelendiğinde ise $\mathrm{Rb}, \mathrm{Sr}, \mathrm{Y}$ bakımından kayaçların kendi aralarında farklı kümelenmeler ve/veya Th, Ba,
$\mathrm{Pb}, \mathrm{Nd}$ için farklı eğilimler gösterdikleri belirlenmiștir. Elementel değișim diyagramları bir bütün içinde değerlendirildiğinde mikrogranit ve granodiyoritin birbirlerinden farklı eğilimler gösterdikleri görülmektedir. Bunun yanısıra, lökogranit bölgedeki en son evre ka- 

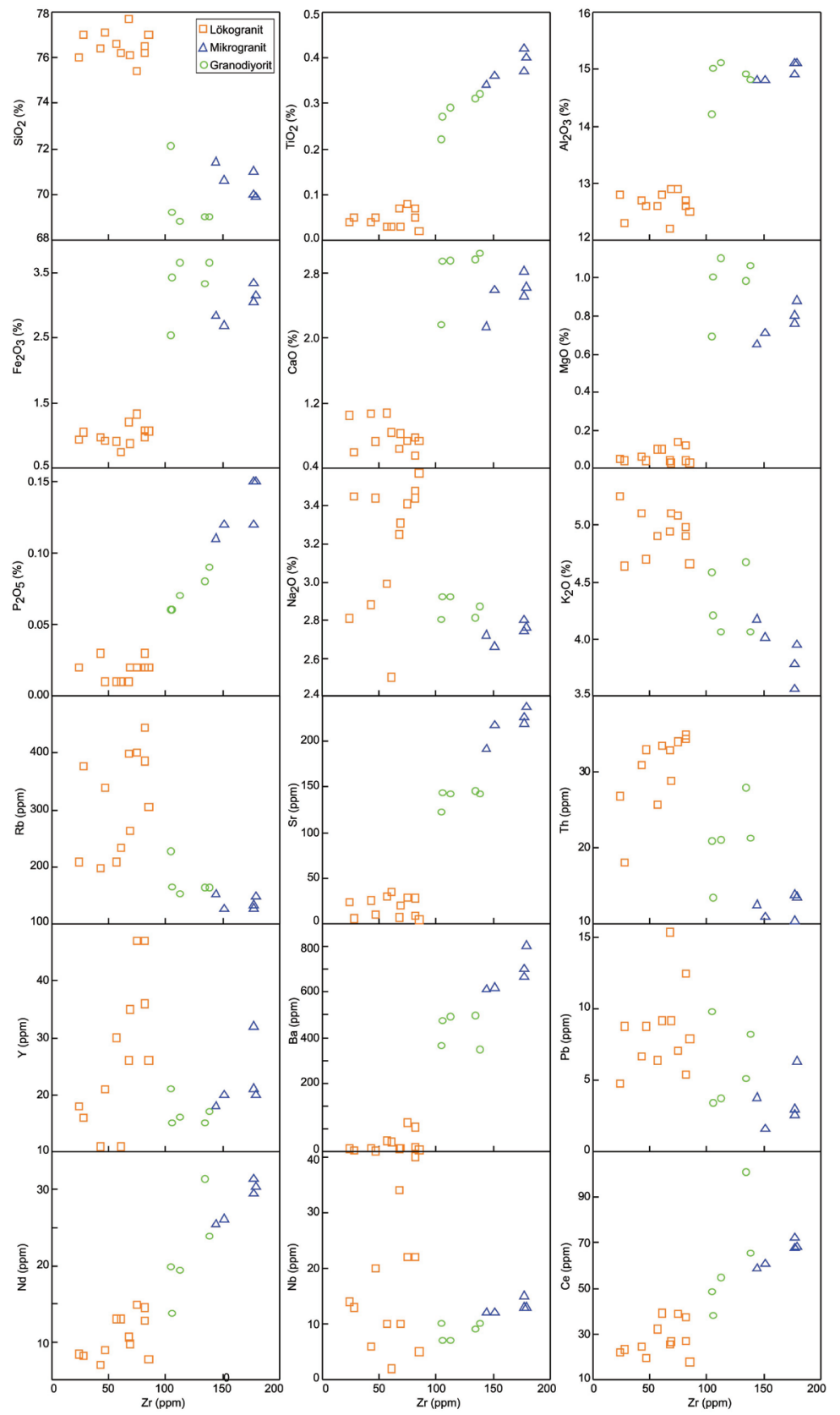

Șekil 4. Zr'ye karșillik element grafikleri.

Figure 4. Plots of elements against $Z$ r.

yaçları temsil etmekte gibi görünmekle birlikte diğer granitlerden farklı bir alanda kümelenmesi ve diğer granitik örneklerle arasında bir boșluk olması nedeniyle diğer kayaçlarla olan jenetik ilișkisini bu grafiklerle belirlemek mümkün görünmemektedir.

Illksel mantoya göre normalize edilmiș (Sun ve McDonough, 1989) çoklu-element dağılım grafiklerinde (Șekil 7a) tüm örneklerde (lökogranitte daha belirgin olmak üzere) negatif $\mathrm{Ba}, \mathrm{Nb}, \mathrm{Sr}, \mathrm{P}$, Eu ve $\mathrm{Ti}$ anoma- lileri gözlenmektedir. Örnekler genel olarak büyük yarıçaplı litofil elementlerce (BiYLE) zengin, yüksek alan dayanımlı elementlerce (YADE) fakir eiğilimler göstermektedir. Lökogranit diğer granitoyidlere göre $\mathrm{Ba}$, hafif NTE, Sr, P, Ti ve YADE'ce daha fakir, ağır NTE'ce daha zengin, BIYYLE ve ağır NTE'ce de geniș dağıımlı desenler sunmaktadır (Șekil 7a). Mikrogranit ve granodiyorit benzer eğilimler ve zenginleșme/ tüketilme düzeyleri göstermekle birlikte, mikrogranit 

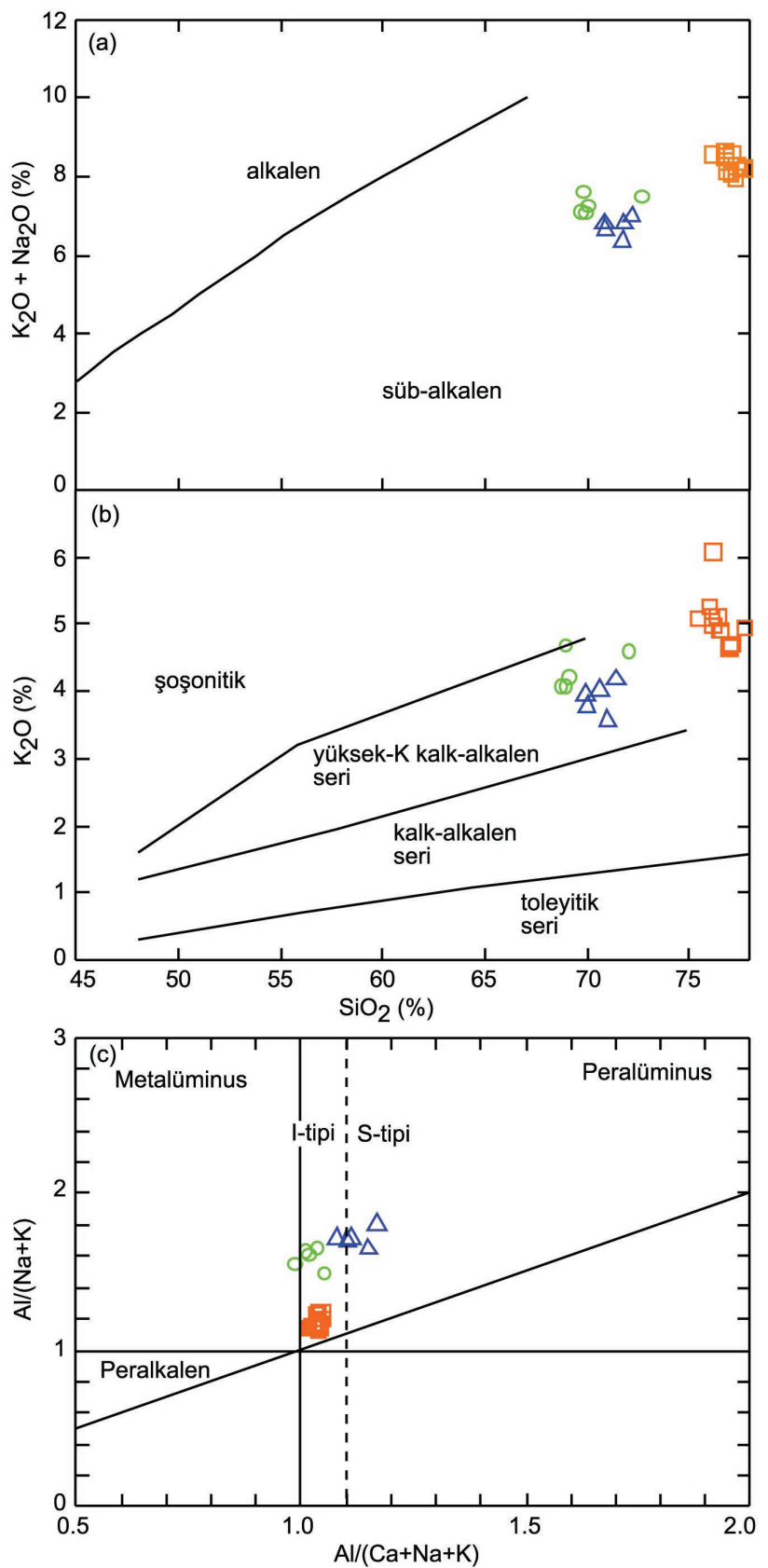

Șekil 5. (a) $\mathrm{SiO}_{2}$ 'ye karșılık $\mathrm{Na}_{2} \mathrm{O}+\mathrm{K}_{2} \mathrm{O}$ grafiği (Irvine ve Baragar, 1971), (b) $\mathrm{SiO}_{2}$ 'ye karșılık $\mathrm{K}_{2} \mathrm{O}$ grafiği (Peccerillo ve Taylor, 1976), (c) Molar Al/(Ca+Na+K) karșılık molar Al/(Na+K) grafiği (Shand (1943)'den sonra I-, S-tipi: Chappell ve White (1974); 1.1 sınırı: Maniar ve Piccoli (1989)) (semboller için Șekil 4'e bakınız).

Figure 5. (a) Plot of $\mathrm{Na}_{2} \mathrm{O}+\mathrm{K}_{2} \mathrm{O}$ against $\mathrm{SiO}_{2}$ (Irvine ve Baragar, 1971), (b) Plot of $\mathrm{K}_{2} \mathrm{O}$ against $\mathrm{SiO}_{2}\left(P_{\text {eccerillo ve }}\right.$ Taylor, 1976), (c) Plot of mol Al/(Na+K) against mol Al/(Ca+Na+K) (I-, S-type: Chappell and White (1974); 1.1 limit: Maniar ve Piccoli (1989) after Shand, 1943) (see Figure 4 for symbols).

granodiyorite göre Ba, Sr, P'ca zengin, Th ve U'ca fakir gözükmektedir (Șekil 7a).

Șekil 7b'de kondrite normalize edilmiș (Sun ve McDonough, 1989) NTE dağılım grafiği verilmektedir. Örneklerde genel olarak hafif NTE zenginleșmesi, ağır
NTE fakirleșmesi görülmektedir. Hafif NTE zenginleșmesi mikrogranit $\left((\mathrm{La} / \mathrm{Yb})_{N}=9.1-14.2\right)$ ve granodiyoritte $\left((\mathrm{La} / \mathrm{Yb})_{N}=8.2-25.8\right)$ lökogranite $\left((\mathrm{La} / \mathrm{Yb})_{N}=1.3-8.0\right)$ göre daha fazladır. Lökogranit en belirgin Eu-negatif anomalisini gösterirken, granodiyorit de mikrogranite göre belirgin negatif Eu-anomalisi göstermektedir. 

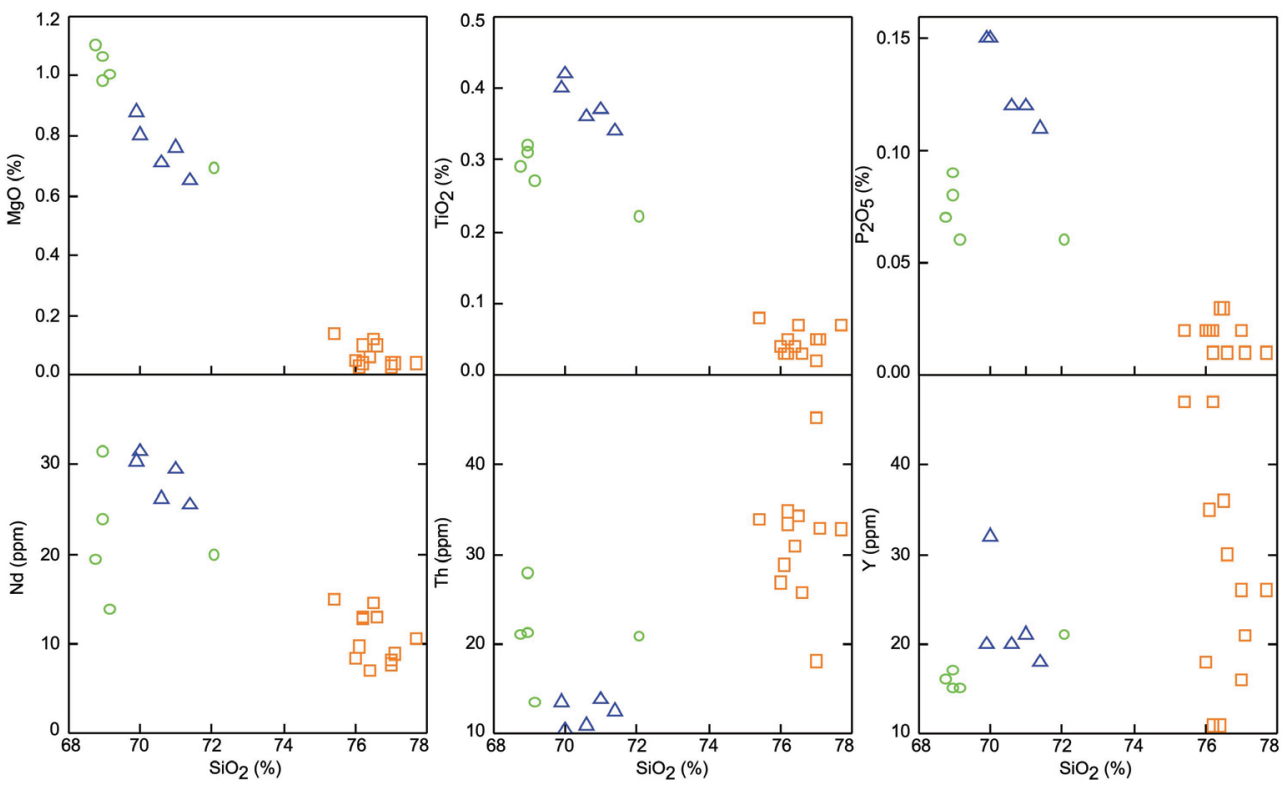

Șekil 6. $\mathrm{SiO}_{2}$ 'ya karșıllık çizdirilen temsili ana ve iz element grafikleri (semboller için Șekil 4'e bakınız).

Figure 6. Plots of representative major oxides and trace elements against $\mathrm{SiO}_{2}$ (see Figure 4 for symbols).
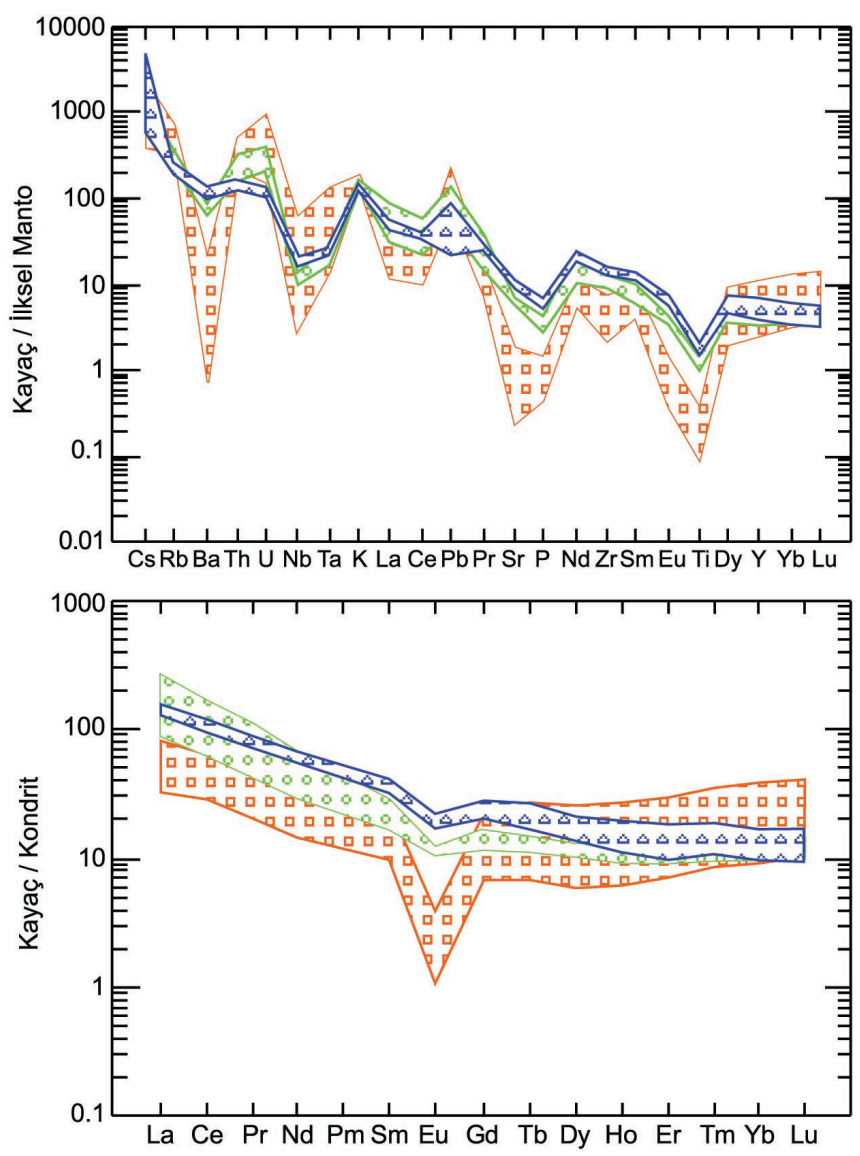

Șekil 7. (a) Çoklu-element dağılım grafiği, (b) nadir toprak elementleri dağıım grafiği (normalizasyon için ilksel manto ve kondrit değerleri Sun ve McDonough (1989)'dan alınmıștır) (semboller için Șekil 4'e bakınız).

Figure 7. (a) Multi-element variation diagram, (b) rare earth element variation diagram (primitive mantle and chondrite normalization values from Sun and McDonough (1989)) (see Figure 4 for symbols). 


\section{MINERAL KIMYASI}

EMB granodiyorit, lökogranit ve mikrogranitini temsil eden örneklerin ana (amfibol, biyotit, feldispat) ve oksit minerallerinden mineral kimyası analizleri yapımıș ve temsili analiz verileri Çizelge 2-4'te verilmiștir. Oksit kristallerinden yapılan analizler tüm kayaçlarda saf manyetiti vermiștir.

\section{Amfibol}

Sadece anklavca zengin granodiyoritte bulunan amfibollerde oksit \% toplamları 96.9-99.3 arasında değișmektedir (Çizelge 2). $\mathrm{FeO}_{(\mathrm{t})}$ 'den ferrik ve ferrus demirin hesaplanması Droop (1987) metodu (stokiometrik yöntem) kullanılarak yapılmıștır. Optik özellikleriyle amfibollerin kalsik tipte oldukları belirlendikten sonra, katyonlar $13 \mathrm{eCNK}$ alt-toplamı (Ca, Na, K hariç katyon toplamının 13 olması) kuralıyla 23 oksijene göre hesaplanmıș ve 15.07- 15.71 arasında değișen katyon toplamı bulunmuștur. Mineral formülü Leake vd. (1997)'ne göre hesaplanmıștır.

Granodiyorit amfibollerinin $\mathrm{Mg} /\left(\mathrm{Mg}+\mathrm{Fe}^{+2}\right)$ değerleri 0.46-0.77 arasındadır. Leake vd. (1997) tarafından yapılan isimlendirmeye göre, amfibollerin tümü $\mathrm{Ca}_{\mathrm{B}} \geq 1.5 \mathrm{fbb}$ (formül birim bașı), $\mathrm{Si}=6.5-7.0 \mathrm{fbb}$, $(\mathrm{Na}+\mathrm{K})_{\mathrm{A}}<0.5 \mathrm{fbb}$, ve $\mathrm{Ca}_{\mathrm{A}}<0.5 \mathrm{fbb}$ değerleriyle petrografik gözlemleri destekler șekilde kalsik amfibol içeriğindedir. Kısmen düșük $\mathrm{Mg} /\left(\mathrm{Mg}+\mathrm{Fe}^{+2}\right)$ değerleri ile ferro-hornblend alanına düșen 4 nokta dıșındaki amfibol analizleri magnesiyo-hornblend bileșimini vermektedir (Șekil 8). İsimlendirme diyagramında (Șekil 8) amphibol verileri farklı dağılım ve eğilimleriyle iki grupta (Grup1: geniș Mg ve Si aralığı, Grup2: dar Mg ve Si aralığı) toplanmıșlardır.

Edenitik ve çermakitik yer değișim mekanizmalarının baskın olduğu bu amfiboller geniș bileșimsel dağılım göstermektedirler ve özelikle $\mathrm{Fe}^{(\mathrm{t})}$ ile $\mathrm{Mg}$ (fbb) içerikleriyle bahsi geçen iki grubu olușturmaktadırlar. Bu farklılașma özellikle C-odacığındaki $\mathrm{Ti}$ ve $\mathrm{Fe}^{+2}$ 'nin $\mathrm{Mg}$ ile yer değișim mekanizmalarında oldukça belirgindir (Șekil 9a,b). Șekil 9'da görüldüğü üzere Mg artıșı ile $\mathrm{Fe}^{+2}$ birbirine paralel iki farklı grupta (Grup1 ve Grup2) azalım gösteren değișim eğrileri ile tanımlanmaktadırlar. Bununla birlikte, Mg-Ti değișim diyagramında az da olsa çakıșan Grup1 ve Grup2'nin davranıșlarına bakıldığında Grup2 artan Mg'a karșı azalan Ti içeriği gösterirken Grup1 pek fazla değișkenlik göstermemektedir. Bu grafiklerde ayırtlanan ve farklı davranıș gösteren gruplar T-odacığındaki
Al[4] ile C-odacığındaki Ti'nin A-odacığındaki $\mathrm{Na}+\mathrm{K}$ ya karșı dağılım grafiklerinde çakıșma göstermekte ve aynı farklılașmayı vermemektedir (Șekil 9c,d). Diğer yandan, granodiyoritte iki grup amfibolün varlığını en iyi A-odacığındaki $\mathrm{K}$ ve $\mathrm{Na}$, T-odacığındaki $\mathrm{Al}^{[4]}, \mathrm{C}$-odacığındaki $\mathrm{Fe}^{+2}$ ve özellikle de Ti'nin Mg/ $\left(\mathrm{Mg}+\mathrm{Fe}^{+2}\right.$ )'ye karșı dağılımı vermektedir (Șekil 10). T-odacığındaki Al (Al $\left.{ }^{[4]}\right)$ artıșıyla A-odacığındaki K artmakta ve iki grup amfibolün varlığı yine kendini göstermektedir (Șekil 10g). Bu elementlerin birbirine karȘı davranıșları amfibollerin dengede oldukları magmanın karakteri hakkında bilgi vermektedir (Ridolfi ve Renzulli, 2012), buna göre bu çalıșmadaki amfiboller kalk-alkalen granodiyoritik magmanın ürünleri olarak değerlendirilmiștir (Șekil 10g).

\section{Biyotit}

EMB granitoyidlerini temsil eden ve analizi yapılan örneklerin tümünde biyotit ana mineral olarak bulunmaktadır. Biyotitin katyon değerlikleri 22 oksijene göre hesaplanmıștır (Çizelge 3).

Granodiyorit, mikrogranit ve lökogranitteki biyotitlerin $\mathrm{Fe}^{+2} /\left(\mathrm{Fe}^{+2}+\mathrm{Mg}\right)$ (=Fe\#) değerleri 0.45-0.61 arasında değișkenlik göstermektedir. Biyotit kristallerinin T-odacığındaki $\mathrm{Al}\left(\mathrm{A}^{[4]}\right)$ içeriği granodiyorit için 2.42$2.54 \mathrm{fbb}$ ve lökogranit için 2.42-2.50 fbb arasında olmak üzere dar bir aralıkta değișim gösterirken mikrogranit için 2.60-2.88 olmak üzere geniș bir aralıkta değișim göstermektedir. Al[4]-Fe\# değișimine dayalı anit-siderofilit-filogopit-estonit isimlendirme dörtgeninde granodiyorit biyotitleri amfiboller gibi iki grup olușturmaktadır. Buna göre, amfibolde olduğu gibi Mg içeriklerindeki farklılık nedeniyle bir grup mikanın (Grup1) tamamı biyotit alanına düșerken diğer grup (Grup2) biyotit alanından filogopit alanına geçiș göstermektedir (Șekil 11a). Mikrogranit ve lökogranitteki biyotitler ise biyotit alanına düșmektedir. Trioktahedral mika sınıflamasında kullanılan $\mathrm{Mg}-\left(\mathrm{Al}{ }^{[\mathrm{iv}]}+\mathrm{Fe}^{3+}+\mathrm{Ti}\right)-$ $\left(\mathrm{Fe}^{+2}+\mathrm{Mn}\right)$ üçgen diyagramında ise bir önceki sınıflamaya göre biyotit alanına düșen granodiyorit, lökogranit, mikrogranitteki biyotitleri Fe-biyotit bileșimini ișaret ederken granodiyoritteki filogopite geçiș gösteren mikalar (Grup1) Mg-biyotit alanına düșmektedir (Șekil 11b).

Granodiyorit biyotitinin iki grubununda Mg (fbb) içeriği mikrogranit ve lökogranittekilere göre daha yüksek olup bu çalıșmada diğer elementlerin Mg'ye karȘı davranıșları incelenmiștir (Șekil 12). Mg'si yüksek olan granodiyorit mikası ile lökogranitin Si içerikleri 
Çizelge 2. Amfibollerden temsili elekron mikroprob analiz verileri (G: granodiyorit). Table 2. Representative electron microprobe data for amphibole (G: granodiorite).

\begin{tabular}{|c|c|c|c|c|c|c|c|c|c|c|c|}
\hline Örnek No & SK-1 & SK-1 & SK-1 & SK-1 & SK-1 & SK-1 & SK-4 & SK-4 & SK-4 & SK-4 & SK-4 \\
\hline Analiz No & 8 & 20 & 28 & 34 & 44 & 69 & 157 & 161 & 178 & 182 & 197 \\
\hline Granitoyid & G & G & $\mathbf{G}$ & $G$ & $\mathbf{G}$ & G & G & $G$ & G & G & $\mathbf{G}$ \\
\hline \multicolumn{12}{|l|}{$(\%)$} \\
\hline $\mathrm{SiO}_{2}$ & 47.40 & 44.95 & 47.94 & 45.20 & 48.89 & 49.99 & 46.77 & 45.39 & 45.25 & 46.06 & 45.87 \\
\hline $\mathrm{TiO}_{2}$ & 0.76 & 0.98 & 0.75 & 0.57 & 0.37 & 0.42 & 0.99 & 1.04 & 0.88 & 1.01 & 0.96 \\
\hline $\mathrm{Al}_{2} \mathrm{O}_{3}$ & 6.66 & 8.28 & 5.56 & 8.91 & 4.89 & 4.46 & 6.87 & 7.31 & 7.01 & 6.90 & 6.99 \\
\hline $\mathrm{FeO}_{(\mathrm{t})}$ & 21.01 & 21.45 & 20.97 & 21.67 & 21.33 & 20.02 & 17.94 & 19.52 & 19.98 & 19.29 & 20.28 \\
\hline MnO & 0.67 & 0.73 & 0.72 & 0.69 & 0.68 & 0.70 & 1.54 & 1.98 & 2.38 & 2.21 & 2.29 \\
\hline MgO & 9.39 & 8.19 & 9.78 & 9.50 & 9.78 & 10.60 & 11.22 & 9.70 & 9.24 & 9.42 & 9.35 \\
\hline $\mathrm{CaO}$ & 11.33 & 11.26 & 11.19 & 8.99 & 11.44 & 11.44 & 10.90 & 10.59 & 10.39 & 10.49 & 10.60 \\
\hline $\mathrm{Na}_{2} \mathrm{O}$ & 0.94 & 1.16 & 0.86 & 0.66 & 0.74 & 0.61 & 1.59 & 1.58 & 1.58 & 1.39 & 1.53 \\
\hline $\mathrm{K}_{2} \mathrm{O}$ & 0.65 & 0.95 & 0.52 & 0.67 & 0.43 & 0.37 & 0.74 & 0.79 & 0.69 & 0.66 & 0.73 \\
\hline $\mathrm{Cr}_{2} \mathrm{O}_{3}$ & 0.04 & 0.01 & 0.02 & 0.03 & 0.00 & 0.04 & 0.00 & 0.01 & 0.00 & 0.00 & 0.03 \\
\hline $\mathbf{P}_{2} \mathbf{O}_{5}$ & 0.05 & 0.00 & 0.03 & 0.00 & 0.00 & 0.03 & 0.00 & 0.02 & 0.00 & 0.04 & 0.01 \\
\hline $\mathbf{F}$ & 0.04 & 0.03 & 0.11 & 0.00 & 0.07 & 0.08 & 0.76 & 0.65 & 0.63 & 0.47 & 0.66 \\
\hline Toplam & 98.94 & 97.99 & 98.45 & 96.89 & 98.62 & 98.76 & 99.32 & 98.58 & 98.03 & 97.94 & 99.30 \\
\hline \multicolumn{12}{|c|}{23 oksijene göre hesaplanan katyon değerleri } \\
\hline Si & 7.00 & 6.78 & 7.10 & 6.60 & 7.23 & 7.32 & 6.86 & 6.76 & 6.79 & 6.88 & 6.80 \\
\hline $\mathrm{Ti}$ & 0.08 & 0.11 & 0.08 & 0.06 & 0.04 & 0.05 & 0.11 & 0.12 & 0.10 & 0.11 & 0.11 \\
\hline Al & 1.16 & 1.47 & 0.97 & 1.53 & 0.85 & 0.77 & 1.19 & 1.28 & 1.24 & 1.21 & 1.22 \\
\hline $\mathrm{Fe}^{+3}$ & 0.67 & 0.59 & 0.75 & 2.02 & 0.68 & 0.64 & 0.80 & 0.91 & 1.00 & 0.86 & 0.96 \\
\hline $\mathrm{Fe}^{+2}$ & 1.93 & 2.11 & 1.84 & 0.63 & 1.95 & 1.81 & 1.40 & 1.52 & 1.51 & 1.56 & 1.55 \\
\hline Mn & 0.08 & 0.09 & 0.09 & 0.08 & 0.08 & 0.09 & 0.19 & 0.25 & 0.30 & 0.28 & 0.29 \\
\hline Mg & 2.07 & 1.84 & 2.16 & 2.07 & 2.16 & 2.32 & 2.45 & 2.15 & 2.07 & 2.10 & 2.07 \\
\hline $\mathrm{Ca}$ & 1.79 & 1.82 & 1.77 & 1.41 & 1.81 & 1.80 & 1.71 & 1.69 & 1.67 & 1.68 & 1.68 \\
\hline $\mathrm{Na}$ & 0.27 & 0.34 & 0.25 & 0.19 & 0.21 & 0.17 & 0.45 & 0.46 & 0.46 & 0.40 & 0.44 \\
\hline K & 0.12 & 0.18 & 0.10 & 0.12 & 0.08 & 0.07 & 0.14 & 0.15 & 0.13 & 0.13 & 0.14 \\
\hline $\mathrm{Cr}$ & 0.00 & 0.00 & 0.00 & 0.00 & 0.00 & 0.00 & 0.00 & 0.00 & 0.00 & 0.00 & 0.00 \\
\hline $\mathbf{P}$ & 0.01 & 0.00 & 0.00 & 0.00 & 0.00 & 0.00 & 0.00 & 0.00 & 0.00 & 0.00 & 0.00 \\
\hline $\mathbf{F}$ & 0.00 & 0.00 & 0.01 & 0.00 & 0.01 & 0.01 & 0.06 & 0.06 & 0.06 & 0.04 & 0.06 \\
\hline Toplam & 15.18 & 15.33 & 15.12 & 14.71 & 15.10 & 15.05 & 15.36 & 15.35 & 15.33 & 15.25 & 15.32 \\
\hline $13 \mathrm{eCNK}^{*}$ & 13.00 & 13.00 & 13.00 & 13.00 & 13.00 & 13.00 & 13.00 & 13.00 & 13.00 & 13.00 & 13.00 \\
\hline $\mathrm{Mg} /\left(\mathrm{Mg}+\mathrm{Fe}^{+2}\right)$ & 0.52 & 0.47 & 0.54 & 0.77 & 0.53 & 0.56 & 0.64 & 0.59 & 0.58 & 0.57 & 0.57 \\
\hline
\end{tabular}

*Amfibolde $\mathrm{Ca}, \mathrm{Na}, \mathrm{K}$ hariç katyon toplamının 13 olması 


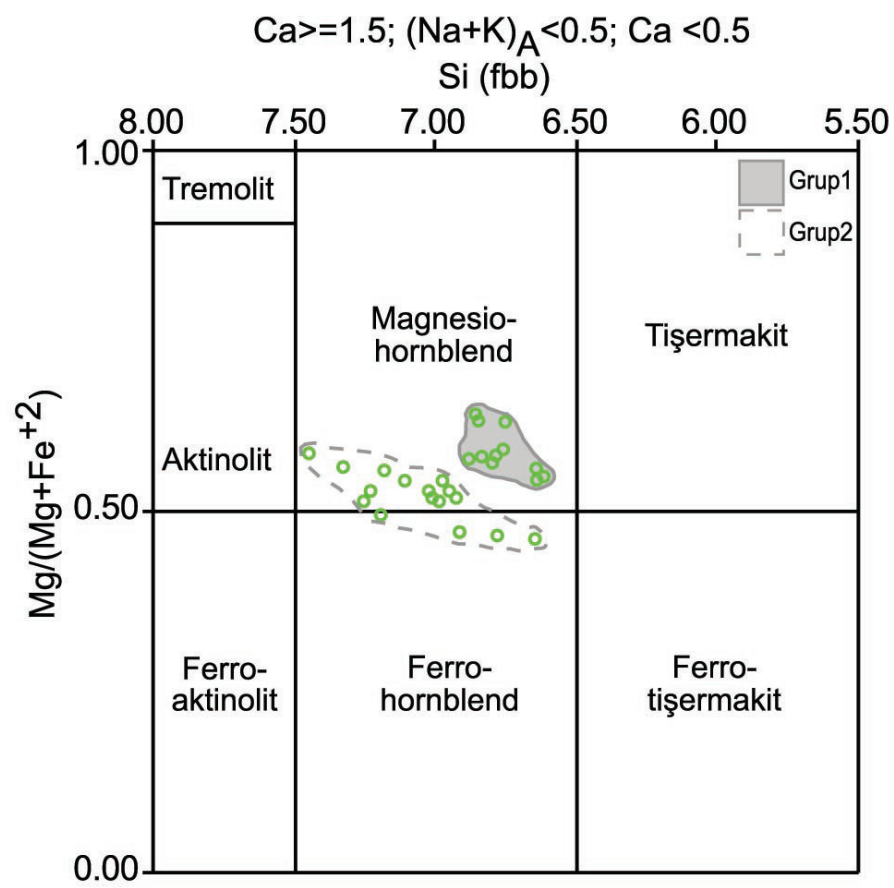

Șekil 8. Granodiyoritte bulunan kalsik amfibollerin Leake vd. (1997)'nin isimlendirmesine göre sınıflaması (semboller için Șekil 4'e bakınız).

Figure 8. Naming of calcic amphiboles in granodorite using nomenclature of Leake et al. (1997) (see Figure 4 for symbols).
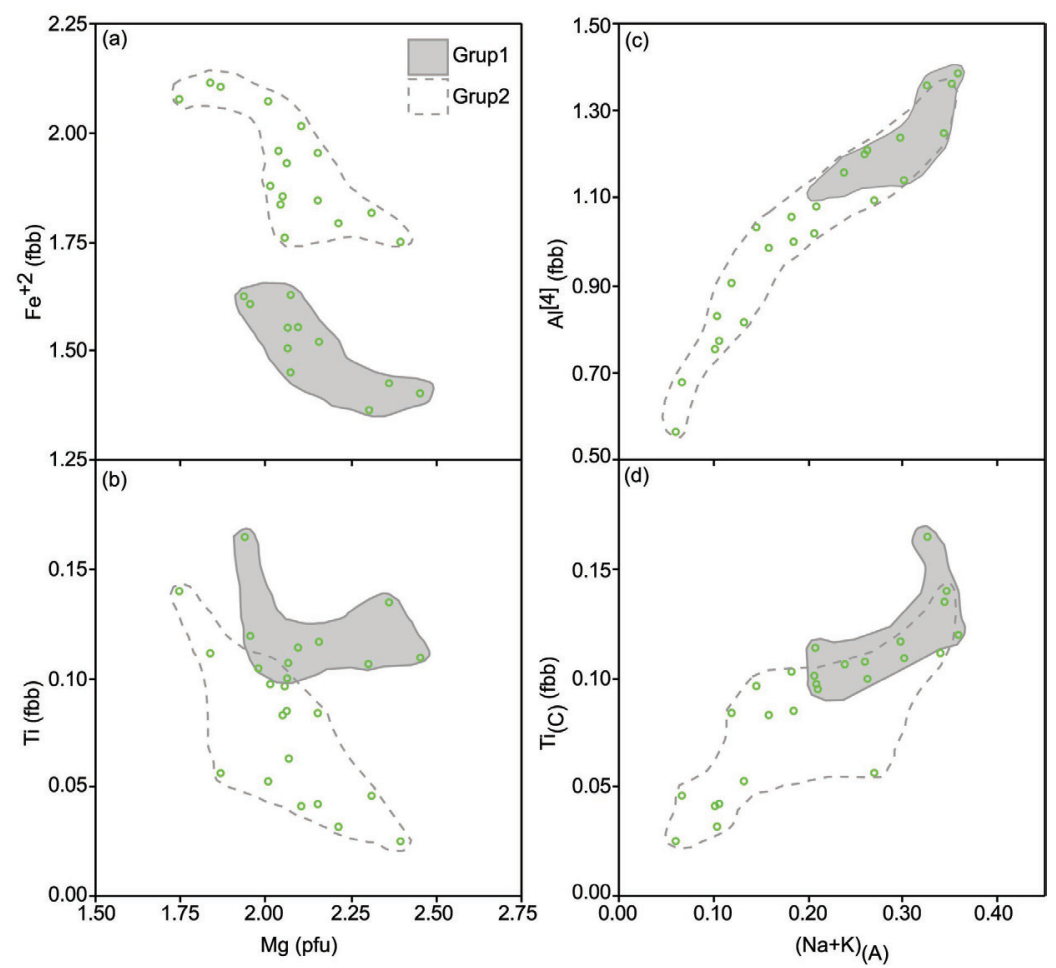

Șekil 9. Granodiyoritte bulunan kalsik amfibollerin (a, b) C-odacığındaki Fe+2 ve Ti elementlerinin Mg'a karșı davranıșları, (c, d) Al[4] ve Ti'nin (Na+K) $)_{A}$ ya karșı değișimleri (semboller için Șekil 4'e bakınız).

Figure 9. (a, b) Plots of $\mathrm{Fe}^{+2}$ and Ti of $\mathrm{C}$-site against $\mathrm{Mg},(\mathrm{c}, \mathrm{d})$ plots of $\mathrm{Al}^{[4]}$ and Ti against $(\mathrm{Na}+\mathrm{K})_{\mathrm{A}}$ for calcic amphiboles in granodiorite (see Figure 4 for symbols). 

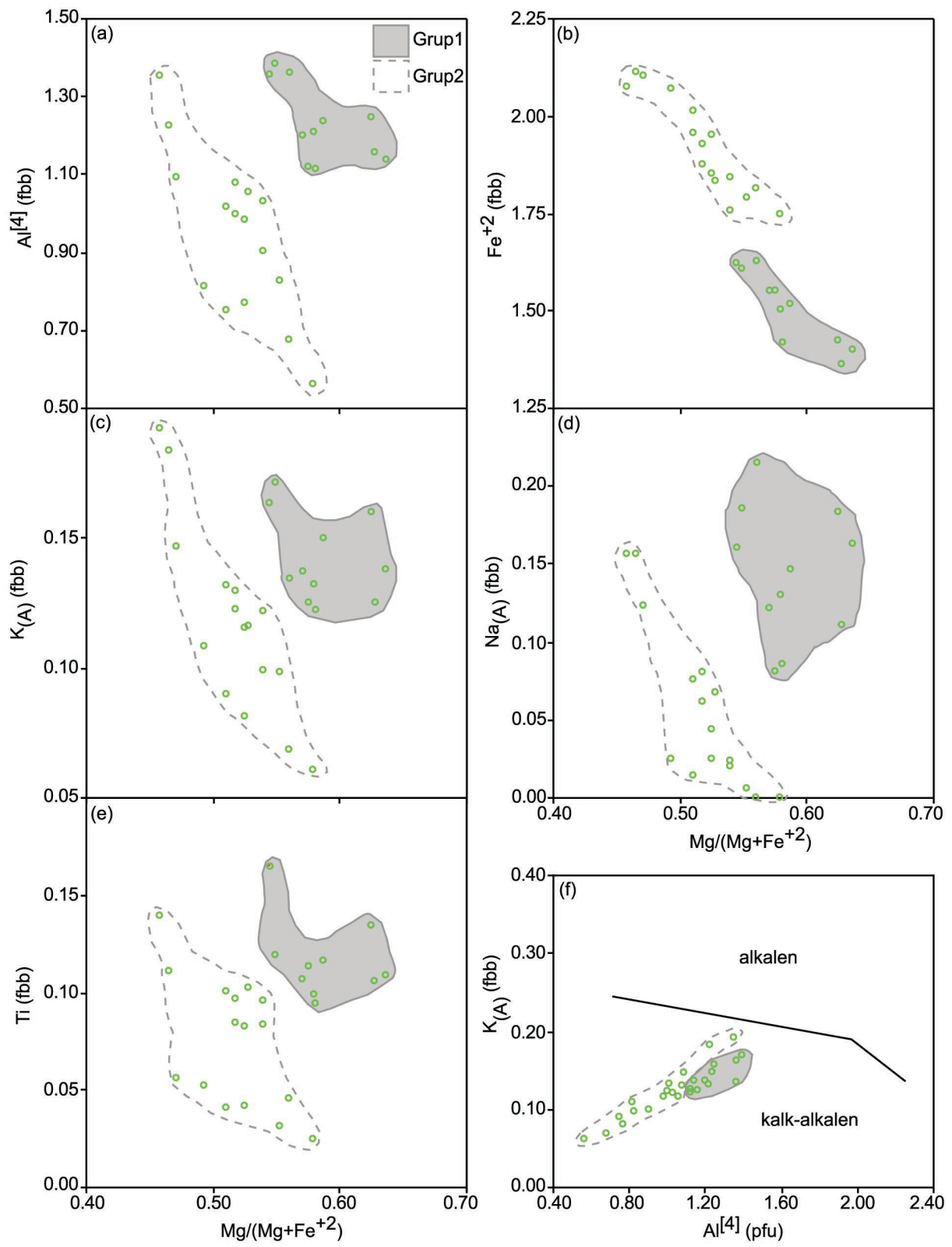

Șekil 10. Granodiyoritte bulunan amfibollerdeki (a-e) katyonların $\mathrm{Mg} /\left(\mathrm{Mg}+\mathrm{Fe}^{+2}\right)^{\prime}$ ye karșı değișimleri, (f) $\mathrm{K}_{(A)}$ 'nın Al[4]'e karșı davranımı ve granodioritin kalk-alkalen karakteri (kalk-alkalen, alkalen alanları Ridolfi ve Renzulli (2012)'den alınmıștır) (semboller için Șekil 4'e bakınız).

Figure 10. For amphiboles of granodiorite (a-e) plots of cations against $\mathrm{Mg} /\left(\mathrm{Mg}+\mathrm{Fe}^{2+}\right)$, (f) plot of $\mathrm{K}_{(\mathrm{AA})}$ against $\mathrm{Al}^{\left[{ }^{[4]} \text { and }\right.}$ calc-alkaline character of granodiorite (fields of calc-alkaline and alkaline from Ridolfi and Renzulli (2012)) (see Figure 4 for symbols).

mikrogranite göre yüksek iken $\mathrm{Al}^{(t)}$ değerleri düșüktür. $\mathrm{Fe}^{(t)}$ içerikleri granodiyoritin kendi içinde $\mathrm{Mg}$ artıkça azalan bir eğilim gösterirken lökogranit ve mikrogranite ait biyotitlerin yüksek Fe ${ }^{(t)}$ içerikleriyle bu doğrultudan farklı bir alanda oldukları ve örtüștükleri gözlenmektedir. Artan Mg'ye karșı Ti değerleri granodiyorit için çok hafif düșen bir eğilim göstermekle birlikte di- ğer kayaçlar için dar Mg aralığında geniș Ti değișimi gözlenmektedir. Lökogranitin Mn içeri diğerlerinkinden oldukça yüksektir. Granodiyorit için artan Mg'ye karșı Mn'de artmakla birlikte mikrogranit hemen hemen sabit değerler göstermektedir. Granodiyorit ve lökogranitin $\mathrm{Na}$ içerikleri örtüșürken mikrogranitinki diğerilerinkinden oldukça fazladır. $\mathrm{K}$ içerikleri tüm ka- 
Çizelge 3. Biyotitlerden temsili elekron mikroprob analiz verileri (M: Mikrogranit; G: Granodiyorit; L: Lökogranit).

Table 3. Representative electron microprobe data for biotite (M: Microgranite; G: Granodiorite; L: Leucogranite).

\begin{tabular}{|c|c|c|c|c|c|c|c|c|c|c|c|}
\hline Örnek No & SK-6 & SK-6 & SK-6 & SK-6 & SK-1 & SK-1 & SK-4 & SK-4 & SK-4 & SK-3 & SK-3 \\
\hline Analiz No & 114 & 133 & 140 & 152 & 12 & 66 & 156 & 171 & 194 & 92 & 93 \\
\hline $\begin{array}{l}\text { Granotoyid } \\
(\%)\end{array}$ & $\mathbf{M}$ & M & $M$ & $\mathbf{M}$ & G & $\mathbf{G}$ & G & $\mathbf{G}$ & $\mathbf{G}$ & $\mathbf{L}$ & $\mathbf{L}$ \\
\hline $\mathrm{SiO}_{2}$ & 35.82 & 34.71 & 35.07 & 34.84 & 36.30 & 35.26 & 36.93 & 36.53 & 36.79 & 36.40 & 36.02 \\
\hline $\mathrm{TiO}_{2}$ & 2.77 & 2.99 & 2.78 & 3.19 & 3.24 & 3.07 & 3.29 & 3.18 & 3.58 & 2.75 & 2.92 \\
\hline $\mathrm{Al}_{2} \mathrm{O}_{3}$ & 19.11 & 17.97 & 18.51 & 18.10 & 14.11 & 14.37 & 13.55 & 13.12 & 13.44 & 14.16 & 13.78 \\
\hline $\mathrm{Cr}_{2} \mathrm{O}_{3}$ & 0.00 & 0.00 & 0.01 & 0.02 & 0.01 & 0.03 & 0.00 & 0.00 & 0.01 & 0.02 & 0.00 \\
\hline $\mathrm{FeO}_{(\mathrm{t})}$ & 21.52 & 23.27 & 23.21 & 22.87 & 25.33 & 24.72 & 20.38 & 21.68 & 21.15 & 23.88 & 24.22 \\
\hline MnO & 0.26 & 0.30 & 0.33 & 0.31 & 0.52 & 0.31 & 1.12 & 1.43 & 1.55 & 2.31 & 2.72 \\
\hline MgO & 7.00 & 7.44 & 7.26 & 7.35 & 8.74 & 8.76 & 11.25 & 10.50 & 10.05 & 6.94 & 7.11 \\
\hline $\mathrm{CaO}$ & 0.06 & 0.00 & 0.04 & 0.07 & 0.02 & 0.01 & 0.02 & 0.01 & 0.03 & 0.06 & 0.03 \\
\hline $\mathrm{Na}_{2} \mathrm{O}$ & 0.11 & 0.15 & 0.12 & 0.12 & 0.06 & 0.05 & 0.10 & 0.06 & 0.08 & 0.05 & 0.08 \\
\hline $\mathrm{K}_{2} \mathrm{O}$ & 9.29 & 9.61 & 9.55 & 9.36 & 9.30 & 8.26 & 9.54 & 9.54 & 9.38 & 8.38 & 9.04 \\
\hline $\mathrm{BaO}$ & 0.41 & 0.08 & 0.05 & 0.00 & 0.00 & 0.10 & 0.10 & 0.09 & 0.05 & 0.01 & 0.23 \\
\hline $\mathrm{NiO}$ & 0.00 & 0.00 & 0.00 & 0.00 & 0.01 & 0.01 & 0.00 & 0.00 & 0.00 & 0.00 & 0.03 \\
\hline $\mathbf{F}$ & 0.00 & 0.04 & 0.00 & 0.00 & 0.19 & 0.23 & 1.40 & 1.27 & 1.32 & 1.52 & 1.61 \\
\hline $\mathrm{Cl}$ & 0.18 & 0.09 & 0.14 & 0.12 & 0.28 & 0.36 & 0.09 & 0.15 & 0.24 & 0.10 & 0.09 \\
\hline Toplam & 96.53 & 96.65 & 97.07 & 96.35 & 98.11 & 95.54 & 97.77 & 97.56 & 97.67 & 96.58 & 97.88 \\
\hline \multicolumn{12}{|c|}{22 oksijene göre hesaplanan katyon değerleri } \\
\hline Si & 5.40 & 5.29 & 5.31 & 5.31 & 5.50 & 5.46 & 5.52 & 5.52 & 5.53 & 5.58 & 5.50 \\
\hline $\mathrm{Ti}$ & 0.31 & 0.34 & 0.32 & 0.37 & 0.37 & 0.36 & 0.37 & 0.36 & 0.40 & 0.32 & 0.34 \\
\hline Al & 3.40 & 3.23 & 3.30 & 3.25 & 2.52 & 2.62 & 2.39 & 2.34 & 2.38 & 2.56 & 2.48 \\
\hline $\mathrm{Cr}$ & 0.00 & 0.00 & 0.00 & 0.00 & 0.00 & 0.00 & 0.00 & 0.00 & 0.00 & 0.00 & 0.00 \\
\hline $\mathrm{Fe}^{+3}$ & 0.49 & 0.53 & 0.53 & 0.52 & 0.58 & 0.58 & 0.46 & 0.49 & 0.48 & 0.55 & 0.56 \\
\hline $\mathrm{Fe}^{+2}$ & 2.17 & 2.37 & 2.35 & 2.33 & 2.57 & 2.56 & 2.04 & 2.19 & 2.13 & 2.45 & 2.48 \\
\hline Mn & 0.03 & 0.04 & 0.04 & 0.04 & 0.07 & 0.04 & 0.14 & 0.18 & 0.20 & 0.30 & 0.35 \\
\hline Mg & 1.57 & 1.69 & 1.64 & 1.67 & 1.97 & 2.02 & 2.51 & 2.37 & 2.25 & 1.59 & 1.62 \\
\hline $\mathrm{Ca}$ & 0.01 & 0.00 & 0.01 & 0.01 & 0.00 & 0.00 & 0.00 & 0.00 & 0.00 & 0.01 & 0.00 \\
\hline $\mathrm{Na}$ & 0.03 & 0.04 & 0.04 & 0.03 & 0.02 & 0.02 & 0.03 & 0.02 & 0.02 & 0.01 & 0.02 \\
\hline K & 1.79 & 1.87 & 1.84 & 1.82 & 1.80 & 1.63 & 1.82 & 1.84 & 1.80 & 1.64 & 1.76 \\
\hline $\mathrm{Ba}$ & 0.02 & 0.00 & 0.00 & 0.00 & 0.00 & 0.01 & 0.01 & 0.01 & 0.00 & 0.00 & 0.01 \\
\hline $\mathrm{Ni}$ & 0.00 & 0.00 & 0.00 & 0.00 & 0.00 & 0.00 & 0.00 & 0.00 & 0.00 & 0.00 & 0.00 \\
\hline $\mathrm{Sr}$ & 0.00 & 0.00 & 0.00 & 0.00 & 0.00 & 0.00 & 0.00 & 0.00 & 0.00 & 0.00 & 0.00 \\
\hline $\mathbf{F}$ & 0.00 & 0.02 & 0.00 & 0.00 & 0.09 & 0.11 & 0.66 & 0.61 & 0.63 & 0.73 & 0.78 \\
\hline Cl & 0.05 & 0.02 & 0.04 & 0.03 & 0.07 & 0.09 & 0.02 & 0.04 & 0.06 & 0.02 & 0.02 \\
\hline Toplam & 15.27 & 15.44 & 15.42 & 15.38 & 15.56 & 15.50 & 15.97 & 15.97 & 15.88 & 15.76 & 15.92 \\
\hline $\mathrm{Mg} /\left(\mathrm{Mg}+\mathrm{Fe}^{+2}\right)$ & 0.42 & 0.42 & 0.41 & 0.42 & 0.43 & 0.44 & 0.55 & 0.52 & 0.51 & 0.39 & 0.40 \\
\hline
\end{tabular}


Çizelge 4. Feldispatlardan temsili elekron mikroprob analiz verileri (M: Mikrogranit; G: Granodiyorit; L: Lökogranit). Table 4. Representative electron microprobe data for feldspar (M: Microgranite; G: Granodiorite; L: Leucogranite).

\begin{tabular}{|c|c|c|c|c|c|c|c|c|c|c|c|}
\hline Örnek No & SK-6 & SK-6 & SK-6 & SK-1 & SK-1 & SK-4 & SK-4 & SK-4 & SK-3 & SK-3 & SK-3 \\
\hline Analiz No & 105 & 125 & 148 & 10 & 22 & 163 & 169 & 184 & 73 & 74 & 89 \\
\hline $\begin{array}{l}\text { Granitoyid } \\
\text { (\%) }\end{array}$ & M & $\mathbf{M}$ & $\mathbf{M}$ & G & G & G & G & $\mathbf{G}$ & $\mathbf{L}$ & $\mathbf{L}$ & $\mathbf{L}$ \\
\hline $\mathrm{SiO}_{2}$ & 56.00 & 59.84 & 65.08 & 62.25 & 65.48 & 65.22 & 64.16 & 64.69 & 65.04 & 67.95 & 65.89 \\
\hline $\mathrm{TiO}_{2}$ & 0.00 & 0.01 & 0.00 & 0.00 & 0.03 & 0.01 & 0.00 & 0.00 & 0.01 & 0.02 & 0.01 \\
\hline $\mathrm{Al}_{2} \mathrm{O}_{3}$ & 27.73 & 24.57 & 18.24 & 24.13 & 18.46 & 18.16 & 22.58 & 18.15 & 18.09 & 20.03 & 21.22 \\
\hline MgO & 0.01 & 0.00 & 0.00 & 0.00 & 0.01 & 0.00 & 0.01 & 0.00 & 0.01 & 0.00 & 0.02 \\
\hline $\mathrm{CaO}$ & 9.80 & 6.27 & 0.02 & 5.70 & 0.05 & 0.05 & 3.88 & 0.00 & 0.00 & 1.03 & 2.50 \\
\hline MnO & 0.02 & 0.03 & 0.00 & 0.03 & 0.00 & 0.01 & 0.00 & 0.01 & 0.01 & 0.00 & 0.00 \\
\hline $\mathrm{FeO}_{(\mathrm{t})}$ & 0.05 & 0.00 & 0.03 & 0.10 & 0.24 & 0.07 & 0.32 & 0.07 & 0.09 & 0.03 & 0.07 \\
\hline $\mathrm{BaO}$ & 0.00 & 0.01 & 0.13 & 0.00 & 0.34 & 0.05 & 0.02 & 0.06 & 0.01 & 0.07 & 0.00 \\
\hline $\mathrm{Na}_{2} \mathrm{O}$ & 5.98 & 7.92 & 1.14 & 8.53 & 1.17 & 0.83 & 9.28 & 0.53 & 0.34 & 11.17 & 10.25 \\
\hline $\mathrm{K}_{2} \mathrm{O}$ & 0.15 & 0.12 & 15.22 & 0.12 & 15.28 & 15.66 & 0.36 & 16.16 & 16.47 & 0.16 & 0.31 \\
\hline Toplam & 99.74 & 98.77 & 99.86 & 100.9 & 101.1 & 100.1 & 100.6 & 99.67 & 100.1 & 100.5 & 100.3 \\
\hline \multicolumn{12}{|c|}{8 oksijene göre hesaplanan katyon değerleri } \\
\hline Si & 2.52 & 2.70 & 3.00 & 2.74 & 3.00 & 3.01 & 2.82 & 3.00 & 3.01 & 2.96 & 2.89 \\
\hline $\mathrm{Ti}$ & 0.00 & 0.00 & 0.00 & 0.00 & 0.00 & 0.00 & 0.00 & 0.00 & 0.00 & 0.00 & 0.00 \\
\hline Al & 1.47 & 1.30 & 0.99 & 1.25 & 0.99 & 0.99 & 1.17 & 0.99 & 0.99 & 1.03 & 1.10 \\
\hline Mg & 0.00 & 0.00 & 0.00 & 0.00 & 0.00 & 0.00 & 0.00 & 0.00 & 0.00 & 0.00 & 0.00 \\
\hline $\mathrm{Ca}$ & 0.47 & 0.30 & 0.00 & 0.27 & 0.00 & 0.00 & 0.18 & 0.00 & 0.00 & 0.05 & 0.12 \\
\hline Mn & 0.00 & 0.00 & 0.00 & 0.00 & 0.00 & 0.00 & 0.00 & 0.00 & 0.00 & 0.00 & 0.00 \\
\hline $\mathrm{Fe}$ & 0.00 & 0.00 & 0.00 & 0.00 & 0.01 & 0.00 & 0.01 & 0.00 & 0.00 & 0.00 & 0.00 \\
\hline $\mathrm{Ba}$ & 0.00 & 0.00 & 0.00 & 0.00 & 0.01 & 0.00 & 0.00 & 0.00 & 0.00 & 0.00 & 0.00 \\
\hline $\mathrm{Na}$ & 0.52 & 0.69 & 0.10 & 0.73 & 0.10 & 0.07 & 0.79 & 0.05 & 0.03 & 0.94 & 0.87 \\
\hline K & 0.01 & 0.01 & 0.90 & 0.01 & 0.89 & 0.92 & 0.02 & 0.96 & 0.97 & 0.01 & 0.02 \\
\hline Toplam & 4.99 & 5.00 & 4.99 & 5.00 & 5.00 & 4.99 & 4.99 & 5.00 & 5.00 & 4.99 & 5.00 \\
\hline
\end{tabular}

yaçlarda hemen hemen örtüșmektedir. Elementlerin tümü özelikle de $\mathrm{Fe}^{(\mathrm{t})}$ ve $\mathrm{Mn}$ içerikleri granodiyoritte Grup1 ve Grup2 olmak üzere amfibolledeki gibi iki biyotit grubunun olduğunu desteklemektedir.

Biyotit kimyası, Abdel-Fattah (1994, 1996) sınıflamasına göre çalıșma kapsamındaki granodiyorit ve lökogranitin kalk-alkalen, mikrogranitin ise peralüminaIı karaktere sahip olduğuna ișaret etmiștir (Șekil 13).

\section{Feldispat}

Kayaçlarda alkali-feldispat ve plajiyoklaz olmak üzere feldispatın her iki tipi de bulunmaktadır ki bunlar- dan çok sayıda EPMA analizi yapılmıștır. Alkali-feldispat komposizyonu tüm örneklerde Or $_{85-98}$ gibi dar bir aralıkta iken plajiyoklaz bileșimleri farklılık göstermektedir (Șekil 14). Plajiyoklaz bileșimi granodiyoritte $\mathrm{An}_{15-49}$ ile oligoklazdan andezine, lökogranitte $A n_{1-17}$ ile albitten oligoklaza ve mikrogranitte $A n_{17-62}$ ile albitten labrodorite değișiklik göstermekte olup oligoklaz tüm örneklerde tanımlanmıștır. Lökogranitte plajiyoklaz bileșimi albitten oligoklaza yayılım göstermekle birlikte albit bileșimi baskındır. Granodiyorit plajiyoklazları da mafik minerallerde belirlenen gruplașma gibi iki grup olușturmaktadır (Șekil 14). Bir grup oligoklaz diğer grup ise andezin vermekte ve 
(a)
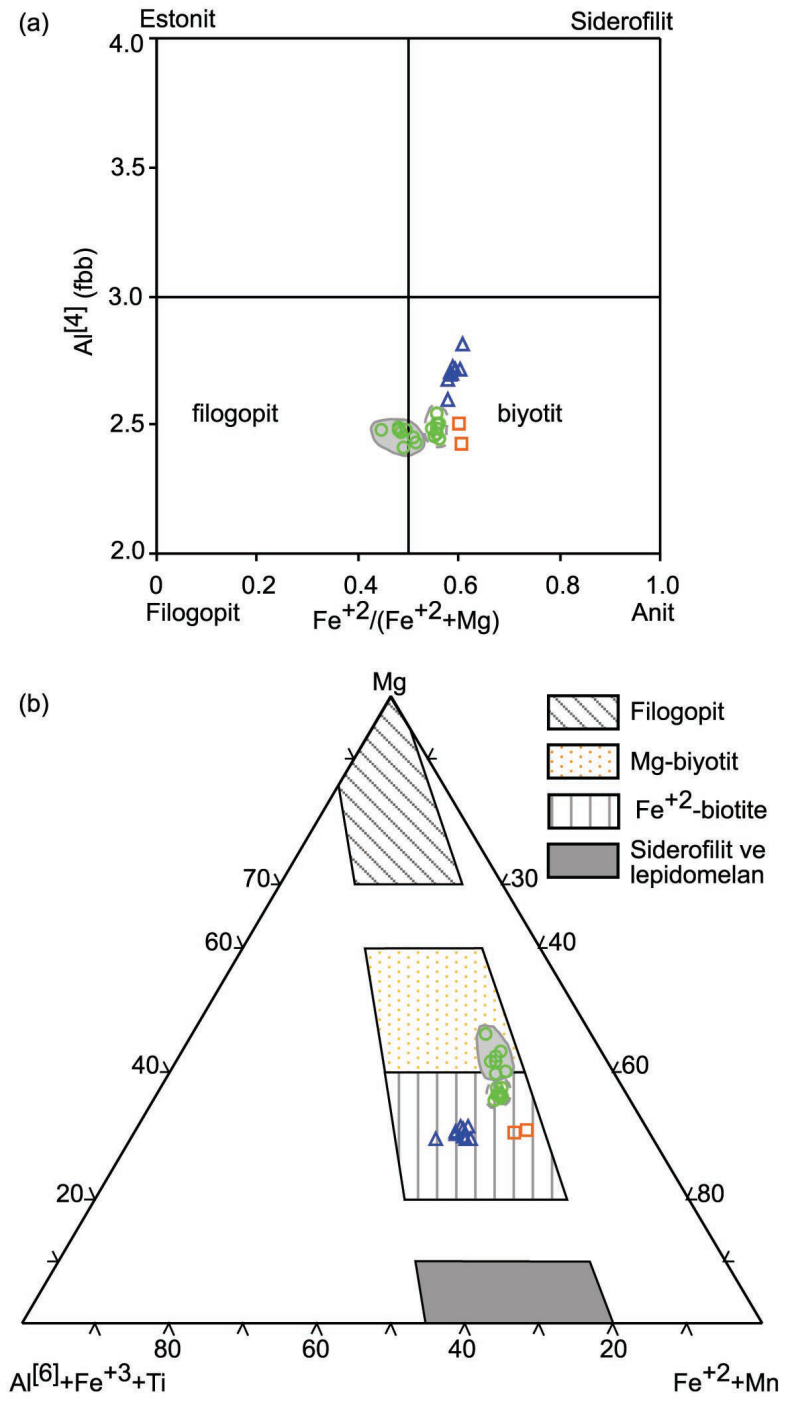

Șekil 11. Mikaların isimlendirilmesi (a) çermakit ve $\mathrm{Mg}-\mathrm{Fe}^{+2}$ yer değișimine dayalı $\mathrm{Al[4]}-\mathrm{Fe}^{+2} /\left(\mathrm{Fe}^{+2}+\mathrm{Mg}\right)$ sınıflaması (Deer vd. (1980)'den Rieder vd. (1998) sonra), (b) Mg-(Fe+2 $+\mathrm{Mn})-\left(\mathrm{Al}{ }^{[6]}+\mathrm{Fe}^{+3}+\mathrm{Ti}\right)$ sınıflaması (Foster, 1960) (semboller için Șekil 4'e bakınız).

Figure 11. Mica nomenclature (a) tchermakite and $\mathrm{Mg}-\mathrm{Fe}^{2+}$ substitution based $\mathrm{Al}^{[4]}-\mathrm{Fe}^{2+} /\left(\mathrm{Fe}^{2+}+\mathrm{Mg}\right)$ classification (Rieder et al. (1998) after Deer et al., 1980). (b) $\mathrm{Mg}-\left(\mathrm{Fe}^{2+}+\mathrm{Mn}\right)-\left(\mathrm{Al}^{[6]}+\mathrm{Fe}^{3+}+\mathrm{Ti}\right)$ classification (Foster, 1960) (see Figure 4 for symbols).

arada kompozisyonel boșluk bulunmaktadır. Oligoklaz göreceli düșük Mg'li mafik minerallerle, andezin ise göreceli yüksek Mg'li mafik fazlarla dengededir.

\section{FiziKOKIMYASAL KOȘULLAR}

Kayaç olușturan mineral toplulukları ve minerallerin kimyasal içerikleri, magmatik kayacı olușturan ergiyiğin jeokimyasal özellikleri ve kristallenme koșullarıyla yakından ilgilidir (Abbott, 1985). Bu nedenle magma kristallenmesi sırasında etken olan basınç, sıcaklık ve oksijen fugasitesi gibi fizikokimyasal parametrelerin belirlenmesinde belli mineral ve mineral topluluklarının kullanılması kaçınılmazdır. Ancak, granitoyidlerde termobarometrik hesaplamalara uygun mineral topluluklarının sınırlı olması basınç ve sıcaklık koșullarının belirlenmesini zorlaștırmaktadır. Bunun yanısıra, sub-solidus soğuma sırasında minerallerin içerikleri kolayca etkilenip değișebilir. Bu nedenle sokulum kayaçlarındaki mineral denge koșullarının incelenmesinde dikkatli olunması gereklidir. Solidus koșulları veren termobarometrenin bulunabilmesi 

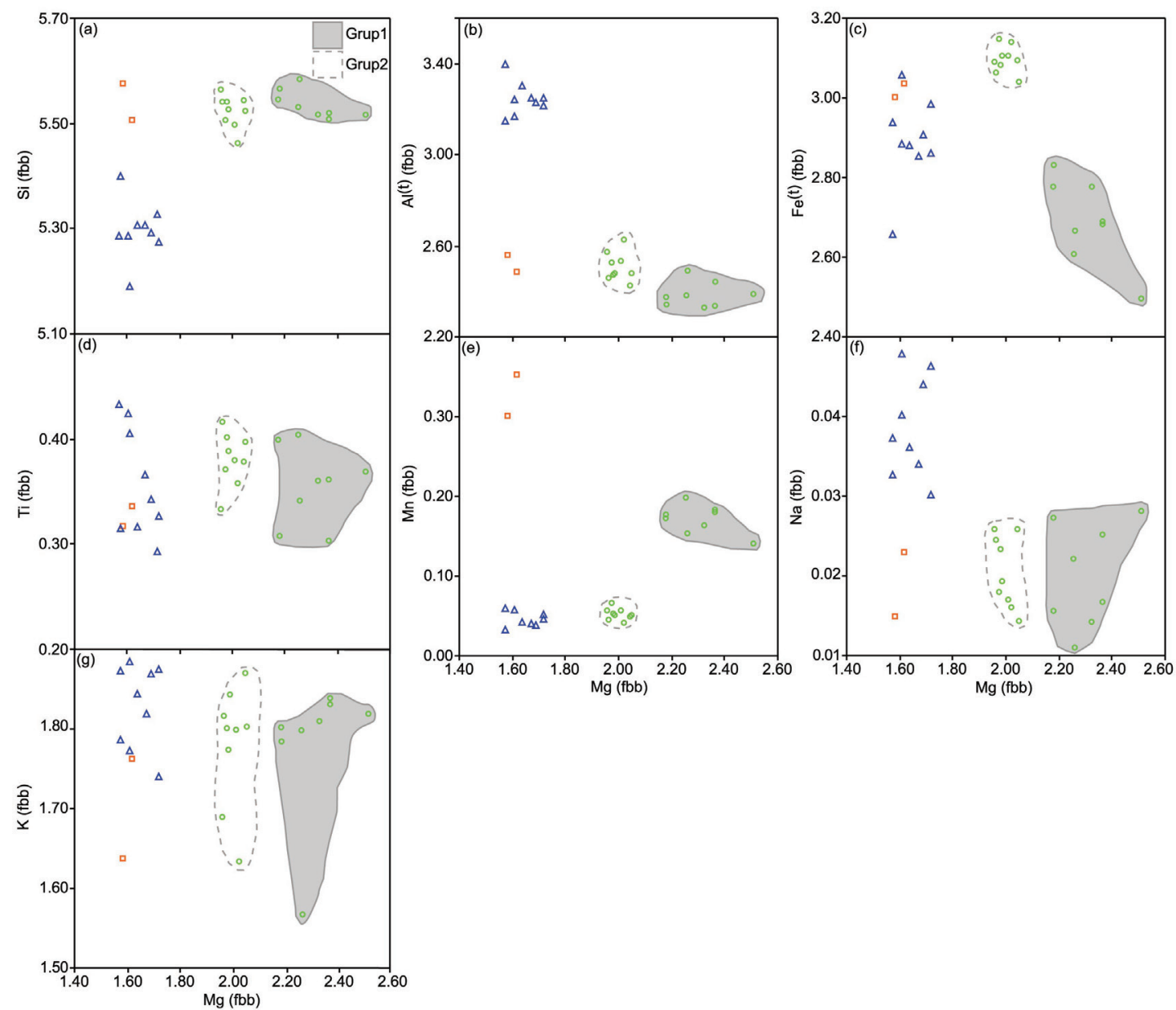

Șekil 12. Biyotitte katyonların Mg (fbb)'a karșı davranıșları (semboller için Șekil 4'e bakınız).

Figure 12. Plots of cations against Mg (pfu) for biotite (see Figure 4 for symbols).

kolay değildir. Magma kristallenme sıcaklığını belirlemek için farklı termometreleri kullanarak deneștirme yapmak en uygunudur ki likudustan sub-solidusa sıcaklık ve basınç belirlemesi yapılabilsin.

Granitoyidlerdeki mineral ve mineral toplulukları (hornblend, biyotit, plajiyoklaz, K-feldispat, kuvars, titanit, Fe-Ti oksitler) baz alınarak çeșitli termobarometrik eșitlikler hazırlanmıștır. Hornblend-Al ${ }^{(t)}$ barometresi (Hammarstrom ve Zen, 1986; Hollister vd., 1987; Johnson ve Rutherford, 1989; Schmidth, 1992; Anderson ve Smith, 1995), hornblend-plajiyoklaz (Holland ve Blundy, 1994) ve hornblend-Ti (Anderson, 1996) termometreleri granitoyidlerdeki mineral dengeleri tartıșılarak hazırlandığından en uygun sonuçları vermektedirler. Birçok granitoyid için hornblend-Al barometresiyle bulunan basınç değerlerinin jeolojik özellikler ve eș-sokulum metamorfiklerden elde ediIen basınçla uyumlu oldukları belirlenmiștir (Ague,
1997; Barnes ve Prestwik, 2000; Moazzen ve Droop, 2004). Magmanın oksidasyonu da mineral toplulukları ve mineral kimyası (ör., titanit + manyetit + kuvars birlikteliği: Wones (1989)) ile bulunabilir. Granitik magmanın yavaș soğuması ilmenit kusmasına ve dolayısıyla manyetitin Ti içeriğince fakirleșmesine neden olacağından (Haggerty, 1976) magmaların orijinal oksijen fugasitesinin belirlenmesi mümkün değildir ancak göreceli yaklașımlar ve hesaplamalar mümkündür (Haggerty, 1976; Wones, 1989; Anderson ve Smith, 1995; Kemp, 2004).

\section{Oksijen Fugasitesi $\left(\mathrm{fO}_{2}\right)$}

Ekecikdağ granitoyidinde belirlenen tek oksit mineralinin özșekilli saf manyetit (Ti-fakir) olması orijinal oksijen fugasitesinin belirlenmesini mümkün kılmamaktadır. Ancak, granitik kayaçlarda öz-șekilli manyetitin erken faz kristallenme ürünü olması magmanın 

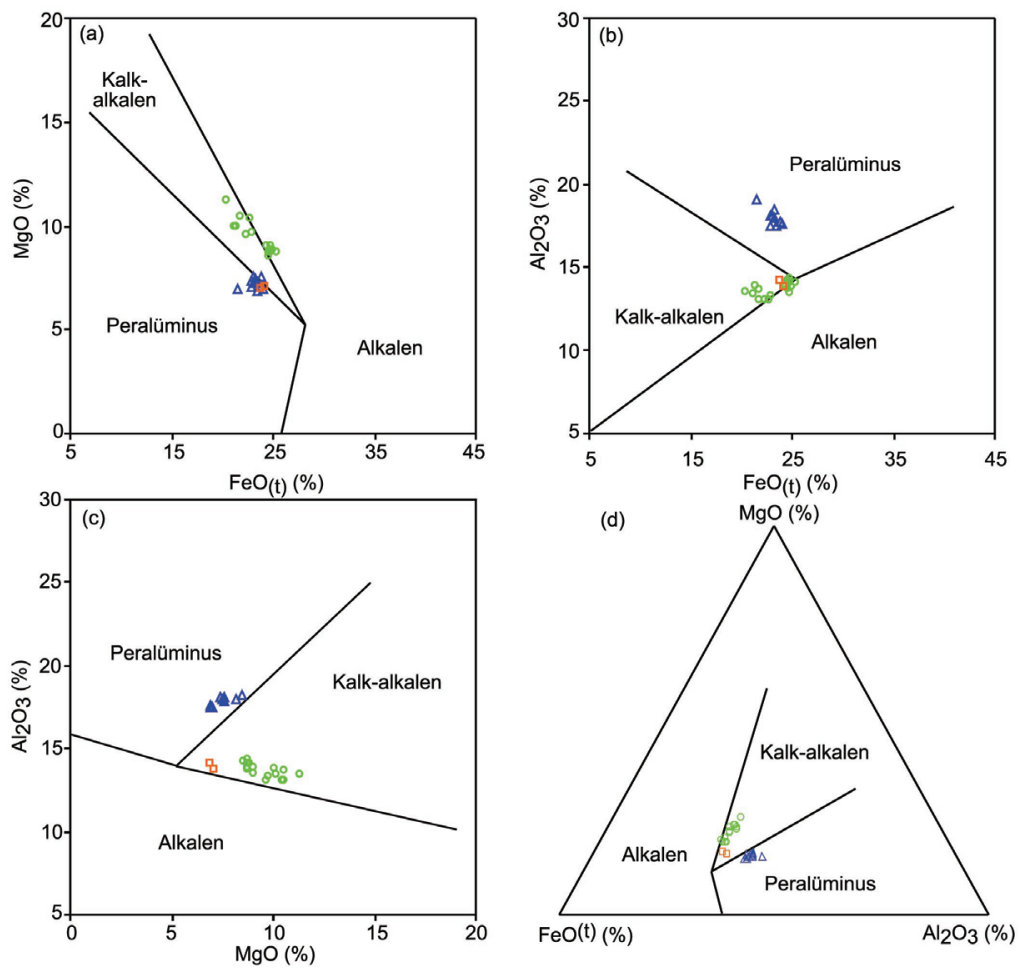

Șekil 13. Biyotitlerin kristallendikleri sistem(ler)in jeokimyasal özelliğini gösteren oksit dağılım diyagramlarındaki yerleri (kalk-alkalen, alkalen ve peralkalen alanlar Abdel-Fattah (1994, 1996)'dan alınmıștır) (semboller için Șekil 4'e bakınız).

Figure 13. Oxide plots of biotites showing chemical character of magmas from which they are crystallized (calcalkaline, alkaline and peralkaline fields from Abdel-Fattah (1994, 1996)) (see Figure 4 for symbols).

kısmen yüksek oksijen fugasitesine sahip olduğuna ișaret eder (Enami vd., 1993). Bununla birlikte, Ekecikdağ granodiyoritindeki titanit-manyetit-kuvars birlikteliği baz alınarak Wones (1989)'un sıcaklık-basınç kontrollü nicel oksijen fugasitesi metodu kullanılarak -20 ve -15 değerleriyle HM (hematit-manyetit) ve FMQ (fayalit-manyetit-kuvars) tamponları arasında yüksek oksijen fugasitesi bulunmuștur (Șekil 15a). $\mathrm{Bu}$ hesaplamada granodiyorit için sırasıyla Holland ve Blundy (1994) ve Anderson (1996) metodlariyla belirlenen sıcaklık ve basınç değerleri kullanılmıștır. Ancak, mikrogranit ve lökogranit için uygun mineral topluluğu bulunmadığından bu metodu uygulamak mümkün olmamıștır. Bu nedenle farklı yaklașımlar da düșünülmüștür. Örneğin, magmanın oksidasyon durumunu en iyi gösteren minerallerden biri de biyotittir (Wones ve Eugster, 1965) ve incelenen tüm kayaç tiplerinde bulunmaktadır. Bu çalıșmadaki granodiyorit dahil lökogranit ve mikrogranitte bulunan biyotitlerin kimyaları Wones ve Eugster'ın (1965) göreceli olarak belirlediği NNO-HM tamponları arasında kalarak (Șekil 15b) yüksek $f \mathrm{O}_{2}$ 'ye ișaret etmektedir.
Sadece granodiyoritte bulunan orta yüksek $\mathrm{Fe}^{(\mathrm{t}) /}$ $\left(\mathrm{Fe}^{(\mathrm{t})}+\mathrm{Mg}\right) \quad(\mathrm{Fe \# =0.40-0.65)}$ değerleriyle magnesiyohornblend ve ferro-hornblend ile beraberlerindeki manyetit yüksek $\mathrm{fO}_{2}$ 'ye ișaret eder (Anderson ve Smith, 1995; Kemp, 2004) (Șekil 15c) ki kayaçtaki hornlend-manyetit-titanit birlikteliği Wones (1989)'a göre bunu destekler.

\section{Jeotermobarometre}

Ekecikdağ granitoyidinin yerleșim sıcaklık ve basıncını kesin olarak belirlemek, jeotermobarometrik hesaplamalar için uygun mineral birlikteliklerinin sınırlı olması nedeniyle zordur. Ancak, granodiyoritin kuvars, iki-feldispat (K-feldispat ve plajiyoklaz), biyotit, hornblend, Fe-oksit ve titanit mineral topluluklari; hornblend-Al jeobarometresi (Hammarstrom ve Zen, 1986; Hollister vd., 1987; Johnson ve Rutherford, 1989; Schmidt, 1992; Anderson ve Smith, 1995) ile hornblend-plajiyoklaz jeotermometresinin (Holland ve Blundy, 1994) kullanımına uygundur. HornblendAl barometresi felsik sokulumların yerleșim basıncını 


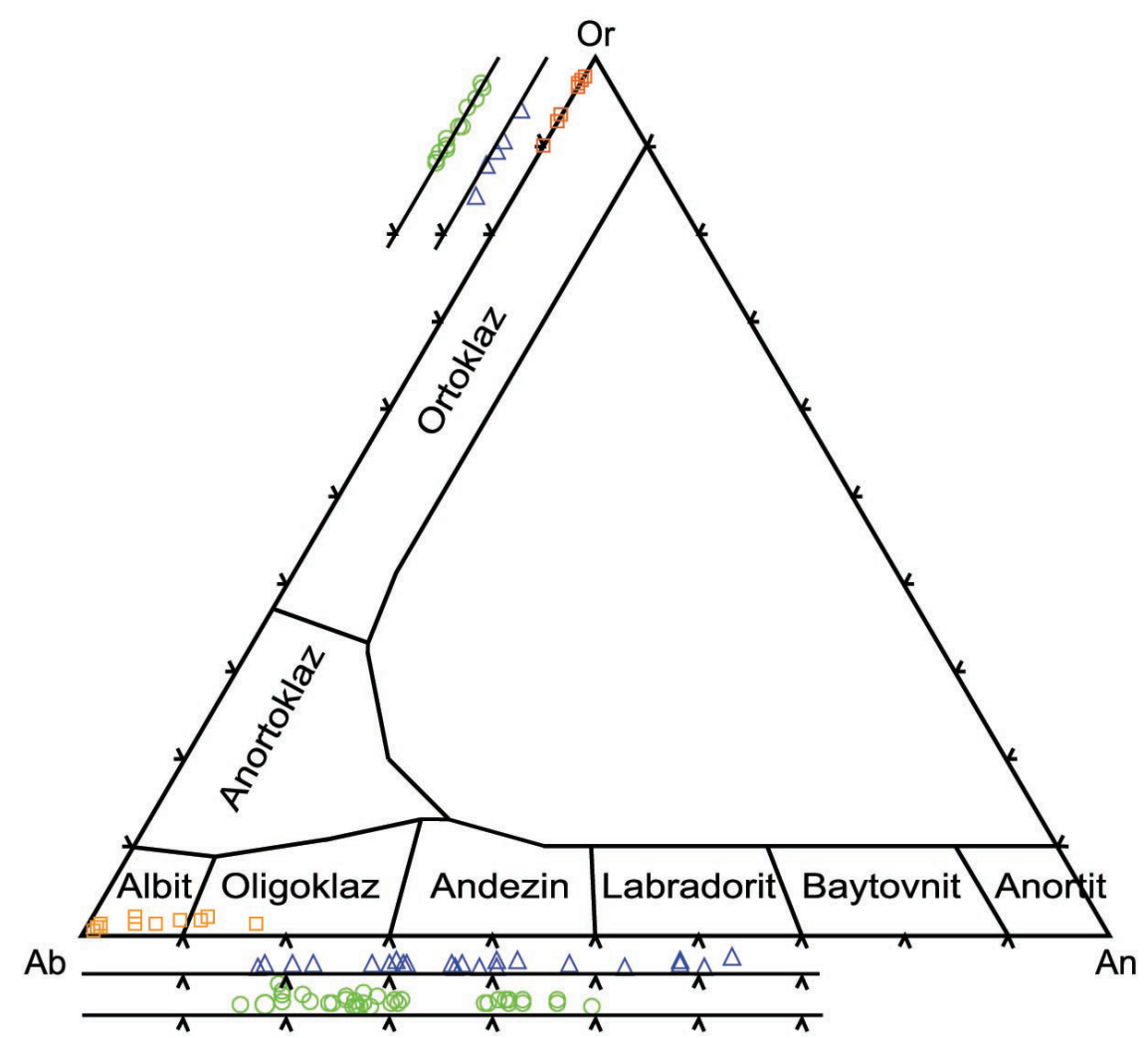

Șekil 14. İncelenen feldispatların feldispat üçgen isimlendirme diyagramındaki yerleri (semboller için Șekil 4'e bakınız).

Figure 14. Plots of concerned feldpars in ternary feldspar classification diagram (see Figure 4 for symbols).

belirlemeye yarar. Yukarıda da belirtildiği üzere granodiyoritteki amfiboller kalsik amfibol olup magnesiove ferro-hornblend bileșimlerindedir. Çalıșılan amfibollerin 23 oksijen ve 13 eCNK baz alınarak hesaplanan $\mathrm{Al}^{(t)}$ değerleri 2.0'dan düșüktür ki Hammarstrom ve Zen (1986)'e göre hornblendlerin $\mathrm{Al}^{(\mathrm{t})} \leq 2.0$ değerleri genelde sığ derinlik sokulumlarına ișaret etmektedir. Ayrıca granitoyidlerin sığ sokulumlar olduklarını destekleyen grafik-büyüme gibi dokusal özellikler de bu granitoyidlerde göze çarpmaktadır. Dolayısı ile söz konusu granitoyidlerin sığ derinlik sokulumları olduğu düșünülmektedir.

Bu çalıșmada, hornblend $\mathrm{Al}^{(t)}$ değerinin basınç kontrolünde olduğunu kabul eden hornblend-Al barometreleri (Hammarstrom ve Zen, 1986; Hollister vd., 1987; Johnson ve Rutherford, 1989; Schmidt, 1992) kullanılarak yapılan hesaplamalar benzer sonuçlar vermiștir. Ancak, granodiyorit için 0.0-4.0 kbar arasında elde edilen basınç aralıkları yüksek hata payı vermiștir. Granodiyorit için elde edilen 1 kbar'dan düșük basınç değerleri, kayaçtaki plajiyoklazların $\left(A n_{15-49}\right)$ hornblend-Al barometresinin uygulanalabilir- liğine en uygun plajiyoklaz $\mathrm{An}_{25-35}$ aralığı (Anderson ve Smith, 1995) dıșındaki değerlerinden kaynaklanabilir. Bunun yanısıra, hornblendde düșük Al içeriği de düșük basınç nedeni olabilir.

Hornblend kimyasına dayalı daha sonraki jeobarometrik çalıșmalarda hornblend-Al ${ }^{(t)}$ içeriğinin ve dolayısı ile $\mathrm{A}^{(\mathrm{t})}$ 'ye göre hesaplanan basıncın sıcaklık ve oksijen fugasitesi kontrolü altında olduğu ortaya koyulmuș ve sıcaklık kontrollü hornblend-Al barometresi hazırlanmıștır (Anderson ve Smith, 1995). Sıcaklık kontrollü bu barometreyi uygulama

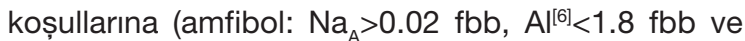
$\mathrm{Si}=6.0-7.7 \mathrm{fbb}$, plajiyoklaz: $\mathrm{An}<90$ : Anderson ve Smith, 1995) bakıldığında, granodiyoritteki Fe-fakir $\left(\mathrm{Fe}^{+3} /\left(\mathrm{Fe}^{3+}+\mathrm{Fe}^{+2}\right)=0.22\right.$ ve yüksek $f \mathrm{O}_{2}$ (Șekil $15 \mathrm{c}$ ) veren magneziyo-hornblendlerin söz konusu sıcaklık kontrollü hornblend-Al barometresinde uygulanabilir oldukları belirlenmiștir. Bu barometrenin uygulanabilmesi için öncelikle sıcaklık hesaplamalarının yapılması gerekmiș ve bu amaçla bu çalıșmada Holland ve Blundy (1994)'nin hornblend-plajiyoklaz termometresi kullanılmıștır. Uygulama öncesi bu termometrenin 
(a)

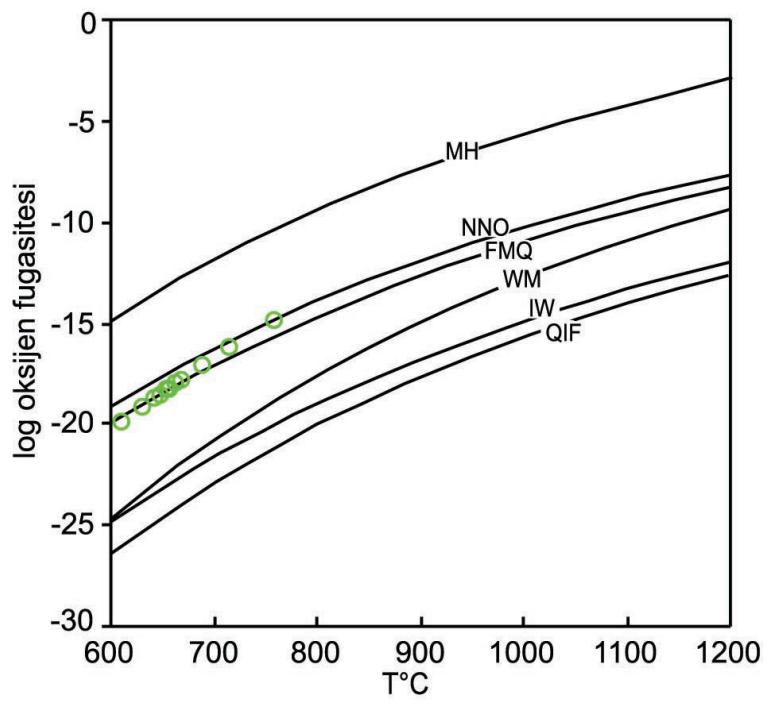

(b)

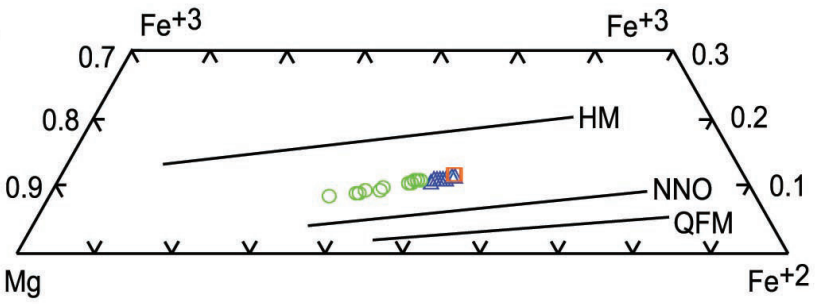

(c)

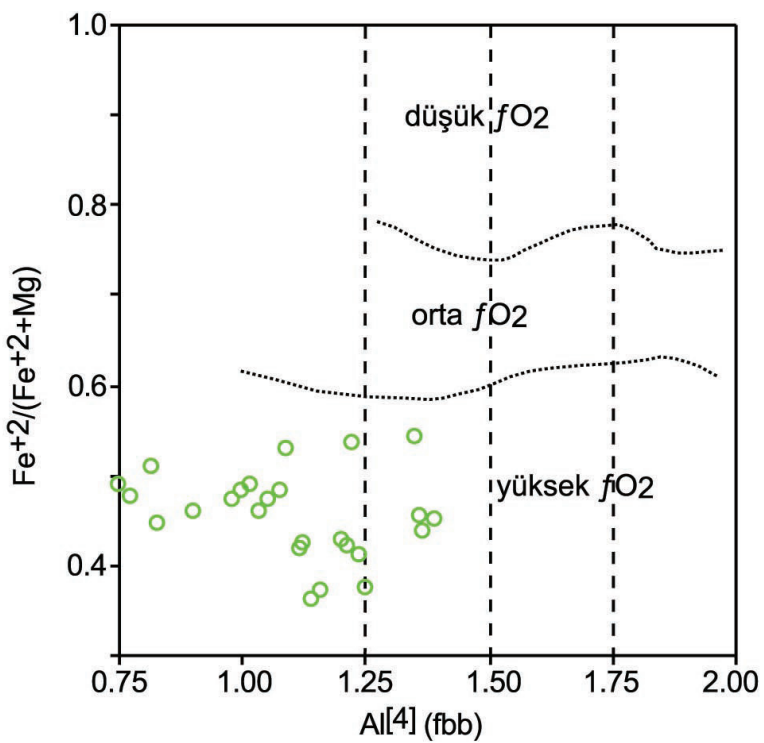

Șekil 15. (a) Sıcaklık - log oksijen fugasitesi diyagramı (MH: manyetit-hematit, NNO: nikel-nikel oksit, FMQ: fayalit-manyetit-kuvars, WM: vustit-manyetit, IW: demir-vustit, QIF: kuvars-demir-fayalit; Frost (1991)), (b) $\mathrm{Fe}^{+3}-\mathrm{Mg}-\mathrm{Fe}^{+2}$ üçgen diyagramını kullanarak biyotit kristallenmesi sırasındaki indirgenme (redoks) koșullarının tahmini (QFM: kuvars-fayalit-manyetit, NNO: Ni-NiO, HM: hematit-manyetit; Wones ve Eugster (1965)), (b) Granodiyorit hornblend bileșimlerinin Anderson ve Smith (1995) oksijen fugasitesi tahmini alanlarında dağılımları (semboller için Șekil 4'e bakınız).

Figure 15. (a) Log oxygen fugacity vs. temperature (MH: magnetite-hematite, NNO: nickel-nickel oxide, FMQ: fayalite-magnetite-quartz, WM: wustite-magnetite, IW: iron-wustite, QIF: quartz-iron-fayalite from Frost (1991)), (b) assumption of redox conditions during crystallization of biotite using $\mathrm{Fe}^{3+}-\mathrm{Mg}-\mathrm{Fe}^{2+}$ triangular diagram (QFM: Quartz-Fayalite-Magnetite, NNO: Ni-NiO, HM: Hematite-Magnetite from Wones ve Eugster (1965)), (b) plots of granodiorite amphiboles on oxygen fugacity assumption diagram of Anderson ve Smith (1995)) (see Figure 4 for symbols). 
çalıșılan granitoyidler için uygulanabilirliği kontrol edilmiștir. Granodiyoritte edenitik ve tremolitik yer değișim mekanizmaları etken olduğundan ve katyon dağılım diyagramlarına göre yaklașı 0.5 kbar'dan 4 kbar'a değișim gösterdiğinden (Șekil 16a) söz konusu termometrenin edenit-tremolit sistemi için belirlenmiș formülü bu çalıșmada kullanılmıștır. Ancak hornblend-plajiyoklaz termometresi de basınca bağlıdır ve bir ön basınç tahmini gerekmektedir. Bu nedenle, sıcaklık kontrollü hornblend-Al barometresinin (Anderson ve Smith, 1995) basınç değerlerinin Schmidt (1992)'in sıcaklık bağımsız hornblend-Al barometresi ile kalibre edilmiș olması sebebiyle bu çalıșmadaki hornblend-plajiyoklaz sıcaklık hesaplamalarında Schmidt (1992)'den elde edilen basınç değerleri kullanılmıștır. Daha sonra bu jeotermometreden elde edilen sıcaklık değerleri Anderson ve Smith (1995)'in sıcaklık kontrollü hornblend-Al barometresinde kullanılmıștır. Basınca ve sıcaklığa bağlı hesaplamalardan en doğru sonucu alabilmek için sabit sıcaklık ve basınç değerlerine ulașıncaya dek elde edilen değerler kullanılarak hesaplamalar tekrarlanmıș yani iterasyon yöntemi uygulanmıștır. Dengedeki hornblend-plajiyoklaz ikililerine (Holland ve Blundy,
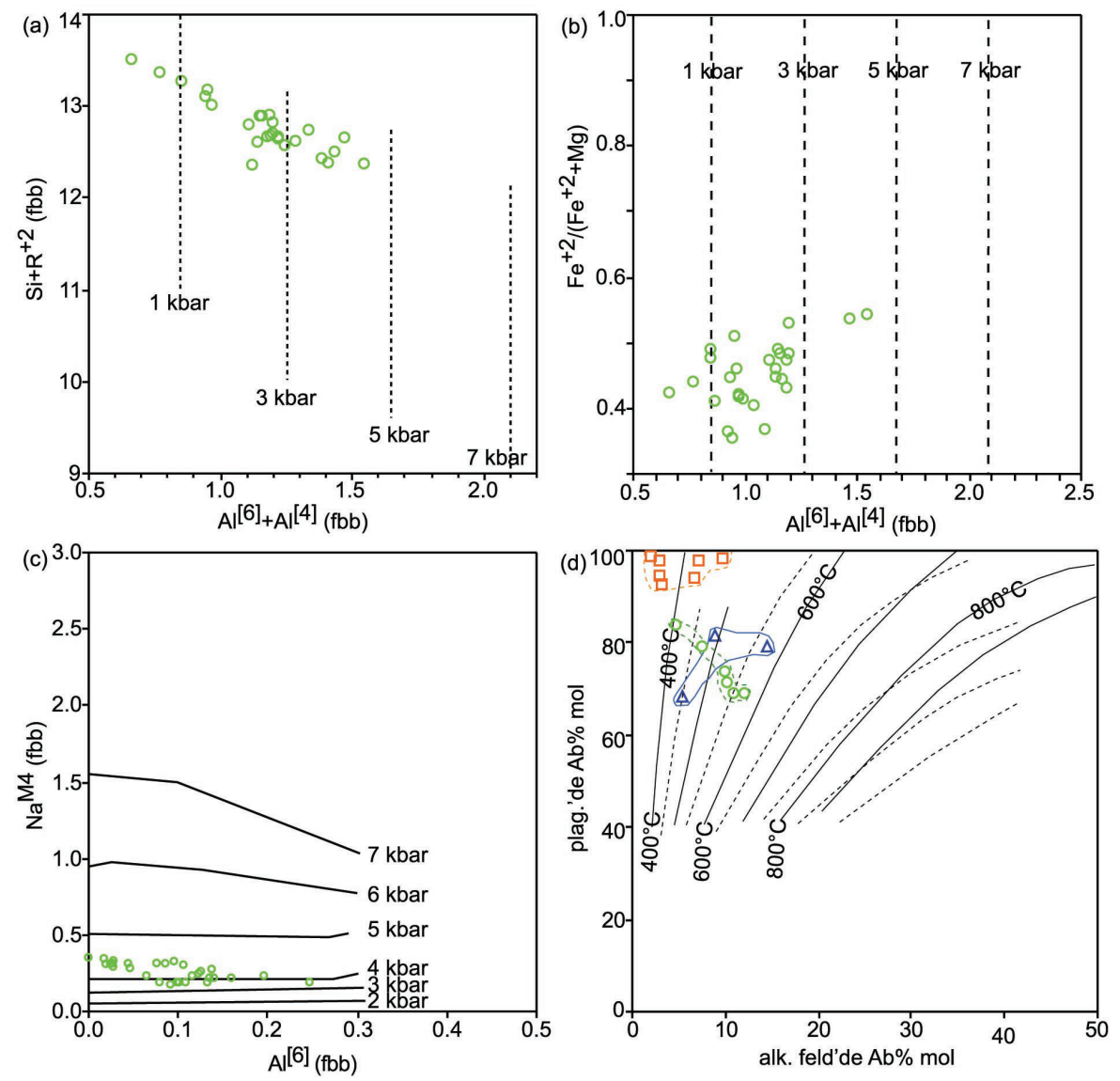

Șekil 16. Granodiyoritteki amfibollerin göreceli basınç tahmini veren (a) $\mathrm{Al}^{[6]}+\mathrm{A}{ }^{[4]}$ e karșı $\mathrm{Si}+\mathrm{R}^{+2}$ diyagramındaki yerleri (izobarlar Anderson ve Smith (1995)'den alınmıștır), (b) $\mathrm{Al}{ }^{[6]}+\mathrm{A}\left[{ }^{[4]}{ }^{\prime} e\right.$ karșı $\mathrm{Fe}^{+2} /\left(\mathrm{Mg}+\mathrm{Fe}^{+2}\right)$ diyagramındaki yerleri (izobarlar Schmidt (1992) kalibrasyonuna göredir ve Anderson ve Smith, (1995)'den alınmıștır), (c) Al[6]'ya karșı $\mathrm{Na}^{\mathrm{M} 4}$ diyagramındaki yerleri (izobarlar Brown (1977)'dan alınmıștır), (d) granitoyidlerin dengedeki feldispat bileșimlerini kullanarak olası dengelenme sıcaklıklarının tahmini (sıcaklık eğrileri sanidin için Stormer (1975) ve mikroklin için Whitney ve Stormer (1977)'dan alınmıștır) (semboller için Șekil 4'e bakınız).

Figure 16. Qualitative pressure assumption for granodiorite using amphibole plots (a) $S i+R^{2+}$ againts $A{ }^{\left[{ }^{[6]}+A{ }^{[4]} \text { where }\right.}$ isobars from Anderson and Smith (1995)), (b) $\mathrm{Fe}^{2+} /\left(\mathrm{Mg}+\mathrm{Fe}^{2+}\right)$ againts $A{ }^{[6]}+A^{\left[l^{[4]}\right.}$ where isobars from Schmidt (1992; Anderson and Smith, 1995). (c) Na ${ }^{M 4}$ againts $A{ }^{[6]}$ where isobars from Brown (1977), (d) assumption of equilibrium temperature using two-feldspar thermometer (isotherms for sanidine from Stormer (1975), for microcline from Whitney ve Stormer (1977) (see Figure 4 for symbols). 
1994) göre yapılan sıcaklık ve sıcaklık kontrollü hornblend Al-barometresine (Anderson ve Smith, 1995) göre yapılan basınç hesaplamaları, granodiyorit için $615-783^{\circ} \mathrm{C}\left(718 \pm 49^{\circ} \mathrm{C}\right)$ ile $1.7-4.7$ kbar sıcaklık ve basınç değerlerini vermiștir (Çizelge 5). Bu barometrenin hata payının \pm 0.5 kbar olduğu dikkate alındığında basıncın <5.2 kbar olduğu kabul edilebilir. Bunun yanısıra, deneștirme yapmak amaçlı nitel yaklașımlar da (Brown, 1977; Anderson ve Smith, 1995) değerlendirilmiștir. Amfibol $\mathrm{Al}^{[4]}+\mathrm{Al}^{[6]}$ 'nın $\mathrm{Fe}^{+2} /\left(\mathrm{Fe}^{+2}+\mathrm{Mg}\right)$ karșısında dağılımına dayalı yarı-kantitatif basınç tahmini (Anderson ve Smith 1995) yukarıda verilen basınç değerlerini desteklemektedir (Șekil 16b). Granodiyorit amfibolü düșük krosit $\left(\mathrm{Na}^{\mathrm{M} 4}<0,36\right)$ içeriyle Brown (1977)'un nitel grafiksel barometresinde 3-4.5 kbar arasında dağılıma ișaret etmektedir (Șekil 16c). $\mathrm{Bu}$ nitel ve nicel barometre verileri deneștirildiğinde granitoyidin sokulum basıncının 3-4.5 kbar arasında olduğu söylenebilir. Hesaplanan basınç değerleri ortalama kabuksal yoğunluk $2.65 \mathrm{~g} / \mathrm{cm}^{3}$ ve $3.3 \mathrm{~km}$ derinlikle 1 kbar basınç artıșı dikkate alınarak yerleșim derinliğinin belirlenmesinde kullanılmıștır. Elde edilen basınç değerleri granodiyorit için 10-16 km sokulum derinliğini vermiștir. Granodiyorit için elde edilen basınç aralığı ve dolayısıyla derinlik oldukça geniștir ve bu durum granitoyitte yoğun miktarda alkali-feldispat fenokristlerinin varlığı ile açıklanabilir. Granitoyitte gözlenen porfiri doku iki farklı çekirdeklenme hızına, dolayısı ile karıșık soğuma ve derinlik geçmișine (basınca) ișaret etmektedir (Zen, 1989).

Mikrogranit ve lökogranitte hornblend mineralinin olmayıșı nedeniyle hornblend barometresi ve uygun biyotit barometrik hesaplama denklemi olmadığından bu granitoyidler için basınç hesaplamaları yapılamamıștır. Ancak, bu tip genç S-tipi granitlerde muskovit ve kuvarsın yanyana dengede olduğu (mikrogranit ve lökogranit örneklerinde olduğu gibi) ve bunun da $\geq$ 10 km'lik yerleșim derinliğini gerektirdiği gözönüne alınarak (minimum ıslak granit solidusu ile muskovit + kuvars üst sıcaklık sınırını temsil eden tepkimenin kesișim noktası: $3.3 \mathrm{kbar}, ~ 10.9 \mathrm{~km}$; Thompson, 1974; Chatterjee ve Johannes, 1974), bu kayaçlar için $\geq 10$ km’lik yerleșim derinliği önerilebilir.

Granodiyorit için hornblend-plajiyoklaz termometresinden (Holland ve Blundy, 1994) elde edilen sıcaklık değerlerinin yanısıra Anderson (1996)'nin hornblend Ti-termometresi $613-799^{\circ} \mathrm{C}\left(677 \pm 48^{\circ} \mathrm{C}\right)$ sıcaklık vermiștir. Yine granodiyorit için, Ridolfi vd. (2010)'nin kalk-alkalen volkanik kayaçlarla kimyasal dengede olan kalsik amfibolleri kullanarak hazırladığı denkle- me göre yapılan hesaplamalar diğer metodlara göre kısmen yüksek sıcaklık $\left(721-818^{\circ} \mathrm{C}, 769 \pm 31^{\circ} \mathrm{C}\right)$ vermiștir. Bunun yanısıra Harris vd. (1999) tarafından biyotitin Ti içeriğine bağlı olarak hazırladığı sıcaklık hesaplamasına göre granodiyorit için $439-615^{\circ} \mathrm{C}$ $\left(535 \pm 51^{\circ} \mathrm{C}\right)$, lökogranit için $456-482^{\circ} \mathrm{C}\left(469 \pm 9^{\circ} \mathrm{C}\right)$ ve mikrogranit için $427-648^{\circ} \mathrm{C}\left(523 \pm 83^{\circ} \mathrm{C}\right)$ sıcaklık değerleri elde edilmiștir. Bu termometrik değerlendirmelerin yanısıra, yavaș soğuyan sokulum kayaçlarının sıcaklığına bir yaklașımda bulunabilmek için iki feldispat jeotermometresi de kullanılabilir (Whitney ve Stormer, 1977; Haselton vd., 1983; Benisek vd., 2004). Bu model, alkali-feldispatın orta yapısal durumunda dahi dengelendiği koșullarda alkalifeldspar ve plajiyoklazın dengelenme sıcaklığının tahminine olanak sağlar. Ekecikdağ granitoyidindeki plajiyoklazlar K-fakir iken alkali-feldispatlar da Ca-fakirdir (Șekil 14). Bu özellik çalıșılan kayaçlarda, albitik içeriğin birarada bulunan plajiyoklaz ve alkali-feldispat arasında dağılımına bağlı iki feldispat termometresinin (Haselton vd., 1983) uygulanabilirliği bakımından oldukça önemlidir. Benisek vd. (2004)'in iki feldispat termometresi kullanılarak yapılan nicel hesaplamalar $427-577^{\circ} \mathrm{C}$ arasında sıcaklık (granodiyorit: $464-577^{\circ} \mathrm{C}$ mikrogranit: $464-565^{\circ} \mathrm{C}$ lökogranit: 427-524 ${ }^{\circ} \mathrm{C}$ ) vermiștir. Sıcaklık eğrileri (Stormer, 1975; Whitney ve Stormer, 1977) kullanılarak yapılan nitel iki feldipat termometrik yaklașımı da nicel olarak elde edilen sıcaklık değerlerini desteklemiștir (granodiyorit: $400-550^{\circ} \mathrm{C}$, mikrogranit: $450-550^{\circ} \mathrm{C}$, lökogranit: 350-450 C) (Șekil 16d).

\section{TARTIȘMA}

\section{Magma Odası Kristallenme Șartları}

Granitoyid yerleșimiyle olușan kontak metamorfik alanlardaki mineral toplulukları magmanın sokulum sıcaklık basınç koșulları hakkında termobarometrik bulguyu verebilir. Ancak metamorfik kayaçlar veya indeks mineralleri tesbit edilemeyebilir. Bu durumda, magma son yerleșim basıncı/derinliğini belirlemenin en iyi yolu granitoyidlerin minerallerini kullanmak olacaktır. Çünkü, magmatik kayaçta bulunan birincil minerallerin kimyasal içerikleri ve dengedeki mineral toplulukları; magmanın jeokimyası, jenezi, olușum süreçleri ve kristallenme sırasındaki fizikokimyasal koșullarla yakından ilgilidir (Abbott, 1985). $\mathrm{Bu}$ bağlamda, Ekecikdağ granitoyidlerini olușturan magma(lar)nın yerleșim basıncı, kristallenme sıcaklı- 
Çizelge 5. Ekecikdağ Magmatik Birliği granitoyidlerinin yerleșim koșulları.

Table 5. Emplacement conditions for the granitoids of the Ekecikdağ Igneous Association.

\begin{tabular}{lccc}
\hline & Sıcaklık & Basınç & Oksijen Fugasitesi \\
\hline granodiyorit & $615-783^{\circ} \mathrm{C} \mathrm{(1)}$ & $0.0-4.0 \mathrm{kbar}(6)$ & $(-20)-(-15)(9)$ \\
& $613-799^{\circ} \mathrm{C} \mathrm{(2)}$ & $1.7-4.7 \mathrm{kbar}(7)$ & HM-FMQ tamponları (11) \\
& $721-818^{\circ} \mathrm{C} \mathrm{(3)}$ & $3-4.5 \mathrm{kbar}(8)$ & NNO-HM tamponları (12) \\
& $439-615^{\circ} \mathrm{C}(4)$ & & \\
& $464-577^{\circ} \mathrm{C} \mathrm{(5)}$ & $\sim 3.5 \mathrm{kbar}(9)$ & NNO-HM tamponları (12) \\
\hline mikrogranit & $427-648^{\circ} \mathrm{C} \mathrm{(4)}$ & & NNO-HM tamponları (12) \\
\hline lökogranit & $464-565^{\circ} \mathrm{C} \mathrm{(5)}$ & $\sim 3.5 \mathrm{kbar}(9)$ & \\
\hline
\end{tabular}

(1) hornblend-plajiyoklaz: Holland ve Blundy (1994), (2) hornblend-Ti: Anderson (1996), (2) hornblend: Ridolfi vd. (2010), (4) biyotit-Ti: Harris vd. (1999), (5) iki-feldispat: Benisek vd. (2004), (6) horblend-Al: Hammarstrom ve Zen (1986), Hollister vd. (1987), Johnson ve Rutherford (1989), Schmidt (1992), (7) horblend-Al: Anderson ve Smith (1995), (8) hornblend-NaM4: Brown (1977), (9) muskovit-kuvars: Thompson (1974), Chatterjee ve Johannes (1974), bölge jeolojisi: Whitney vd. (2003), (10) titanit-manyetit-kuvars: Wones (1989), (11) Sıcaklık - log fO2: Frost (1991), (12) biyotit: Wones ve Eugster (1965).

ğı, oksijen fugasitesi gibi parametrelerine, belli mineral ve mineral topluluklarını kullanalarak nitel ve nicel yaklașımlarda bulunulmuș, petrografik ve jeolojik özellikler ile birlikte tartıșılmıștır.

Yavaș soğuma nedeniyle granitik magmaların orijinal oksijen fugasitesi belirlenemediğinden sadece göreceli yaklașımlar ve hesaplamalarda bulunabilir (Haggerty, 1976; Wones, 1989; Anderson ve Smith, 1995; Kemp, 2004). Ekecikdağ kayaçlarının tümünde belirlenen tek opak mineral özșekilli saf manyetittir ve erken faz kristallenme ürünü olması magmanın kısmen yüksek oksijen fugasitesine $\left(\mathrm{fO}_{2}\right)$ sahip olduğuna ișaret eder (Enami vd., 1993). Sadece granodiyoritte bulunan magnesiyo-hornblend ve beraberindeki manyetit yüksek $\mathrm{fO}_{2}$ 'yi desteklemektedir (Anderson ve Smith, 1995; Kemp, 2004) (Șekil 15a) ki kayaçtaki titanit-manyetit-kuvars birlikteliğine dayalı Wones (1989) nicel hesaplamasından elde edilen değerler (-20 ve -15 : HM (hematit-manyetit) ve FMQ (fayalitmanyetit-kuvars)) bunu desteklemektedir. Kırșehir civarındaki OAGnden Wones (1989) eșitliği kullanılarak yapılan hesaplamalarda HM-FMQ tamponları arasını vermiș (Illbeyli, 2005) olup bu çalıșmadan elde edilenlerle uyumludur.

Mikrogranit ve lökogranitte hornblend bulunmadığından bu minerale bağlı metod uygulanamamıș ve tüm kayaç tiplerinde var olan biyotit kullanılarak nitel bir yaklașımda bulunulmuștur. Biyotit kimyası kayaçların tümünde NNO-HM tamponları arasında kalarak (Wones ve Eugster, 1965) (Șekil 15b) yüksek $f_{2}$,'ye ișaret etmiștir. Oksijen fugasitesi sıcaklıkla doğru orantılı olarak azalmaktadır (Șekil 15a). Düșen sıcakIıkla azalma gösteren oksijen fugasitesinin soğuma sırasında yeniden dengelenmeye ișaret ettiği önerilmiștir (illbeyli, 2005).

Granodiyoritin mineral içeriği (kuvars, K-feldispat, plajiyoklaz, biyotit, hornblend, Fe-oksit, titanit) hornblend-Al jeobarometresi (Hammarstrom ve Zen, 1986; Hollister vd., 1987; Johnson ve Rutherford, 1989; Schmidt, 1992; Anderson ve Smith, 1995) ve hornblend-plajiyoklaz jeotermometresinin (Holland ve Blundy, 1994) kullanımına olanak sağlamıștır. Granodiyorit için 1.7-4.7 kbar arasında basınç aralığı elde edilmiștir. Bu barometrenin hata payının $\pm 0.5 \mathrm{kbar}$ olduğu dikkate alınarak basıncın $<5.2$ kbar olduğu kabul edilmiștir. Bunun yanısıra, deneștirme amaçlı yapılan nitel yaklașımlarda (Brown, 1977; Anderson ve Smith, 1995) elde edilen değerleri desteklemiștir (Șekil 16b,c). Amfibolün düșük krosit $\left(\mathrm{Na}^{\mathrm{M} 4}<0.36\right)$ içeriyle Brown (1977)'un nitel grafiksel barometresinde 3-4.5 kbar arasında dağılıma ișaret etmiștir (Șekil 16c). Bu nitel ve nicel barometre verileri deneștirilerek granodiyoritin yerleșim basıncı 3-4.5 kbar arasına 
sınırlandırılmıștır. Çalıșma alanında bu basınç değerlerini destekleyebilecek jeolojik bulgu bulunamamıștır. Ancak literatürde bu hornblend Al-barometresini kullanarak granitoyidler için hesaplanan basınç değerlerinin jeolojik özellikler ve eș-sokulum metamorfik birliklerinden elde edilen basınç ile uyumlu olduklarını belirleyen çalıșmalar vardır (Ague, 1997; Barnes and Prestwik, 2000; Moazzen ve Droop, 2004). Bunun yanısıra, bu çalıșmadaki I-tipi granodiyorit için elde edilen yerleșim basıncı Orta Anadolu'daki diğer I-tipi granitoyidler için saptanan basınç değerleriyle (Yozgat: 2-4 kbar (Boztuğ vd., 2007a); Kırșehir (Kaman): 2-5 kbar (Otlu vd., 2001), 2.6-5.5 kbar (Ilbeyli, 2005)) uyumludur. Hesaplanan basınç değerleri, ortalama kabuksal yoğunluk $2.65 \mathrm{~g} / \mathrm{cm}^{3}$ ve $3.3 \mathrm{~km}$ derinlikle 1 kbar basınç artıșı dikkate alınarak yerleșim derinliğinin 10-15 km olduğu önerilmektedir. Granitik bir kayaçtaki porfiri doku iki farklı çekirdeklenme hızına dolayısı ile karıșık soğuma ve derinlik geçmișine (basınca) ișaret ettiğinden (Zen, 1989) Ekecikdağ granodiyoritindeki alkali-feldispat fenokristleri geniș basınç ve derinlik aralığı açıklamaktadır. Granodiyoritte sulu mafik mineral (hornblend, biyotit), titanit ve apatit bulunması magmanın yüksek su ve uçucu içeriğine ișaret etmektedir ki bu içerikteki yüksek sıcaklıklı magma tümüyle kristallenmeden kıtasal kabuğun sığ derinliklerine kadar yükselebilir (Helmy vd., 2004). Bunun yanısıra Orta Anadolu'daki gerilmeyle üst kabuğun sıyrılması magma yerleșiminin orta-sığ derinlikte gerçekleșmesini açıklamaktadır (Whitney vd., 2003).

Mikrogranit ve lökogranitte uygun mineral ve/veya mineral topluluğu olmaması nedeniyle barometrik hesaplama yapılamamıștır. Ancak, bu granitoyitlerin dengedeki muskovit ve kuvars içerikleri dikkate alınarak yerleșim basıncının $>3.3$ kbar ve derinliğinin ise $\geq 10$ olduğu söylenebilir. Çünkü bu tip genç S-tipi granitlerde bulunan dengedeki muskovit + kuvars ikilisinin üst sıcaklık sınırını temsil eden tepkimeyle minimum ıslak granit solidusu kesișim noktası $~ 3.3 \mathrm{kbar}$ basınç ve $\sim 10.9 \mathrm{~km}$ derinlikte olmaktadır (Thompson, 1974; Chatterjee ve Johannes, 1974). Bunun yanısıra, Orta Anadolu'da S-tipi granitik magma; yüksek sıcaklık orta kıtasal kabuk meta-sedimenter kayaçlarının basınç azalmasıyla 12 km'den sığ derinlikte kısmi ergimesiyle oluștuğu kabul edilmektedir (Üçkapılı granitoyid: Whitney vd., 2003). Bu bilgi de dikkate alındığında mikrogranit ve lökogranitin yerleșim derinliği 11-12 km arasına sınırlandırılabilir. S-tipi granitik magmanın olușum yerinden çok fazla yükselmeden yerleștiği söylenebilir.
Su doygun magmatik sistemlerde solidus sıcaklıkları iyi bilindiğinden, hornblend-biyotit \pm muskovit bulunan Ekecikdağ granitik kayaçlarında minerallerin su doygun solidusda dengeye ulaștıkları düșünülerek magmanın kristallenme sıcaklığı tahmin edilebilir. Basıncın >3 kbar olduğu durumda su doygun granitin solidusu $650-675^{\circ} \mathrm{C}$ izotermindedir (Wyllie, 1984). Ancak granitoyidlerden yapılan termobarometrik değerlendirmeler, minerallerin solidus üzerinde korunması veya buhar doymamıș koșullar nedeniyle çoğunlukla $>700^{\circ} \mathrm{C}$ verdiğini göstermektedir (Anderson ve Smith, 1995). Ekecikdağ granitoyidindeki mineral birliktelikleri düșünülerek farklı termometrik yaklașımlar kullanılmıș ve makul bir kristallenme sıcaklığı elde edilmeye çalıșılmıștır. Granodiyorit için hornblend-plajiyoklaz (Holland ve Blundy, 1994), hornblend-Ti (Anderson, 1996) termometrik hesaplamaları sırasıyla $615-783^{\circ} \mathrm{C}\left(718 \pm 49^{\circ} \mathrm{C}\right)$ ve $613-799^{\circ} \mathrm{C}$ $\left(677 \pm 48^{\circ} \mathrm{C}\right)$ değerlerini vermiștir. Bunlara ek olarak, kalk-alkalen volkanik kayaçlarla kimyasal dengede olan kalsik amfiboller kullanılarak hazırlanan denklem (Ridolfi vd., 2010) ile kısmen yüksek $\left(721-818^{\circ} \mathrm{C}\right.$, $769 \pm 31^{\circ} \mathrm{C}$ ) sıcaklık değerleri bulunmuștur. Hornblend temelli termometrik hesaplamaların yanısıra biyotitTi termometresi (Harris vd., 1999) de kullanılmıștır. Biyotitin kayaç tiplerinin tümünde bulunması granodiyoritle birlikte mikrogranit ve lökogranit içinde bir yaklașımda bulunulmasına olanak sağlamıștır. Buna göre; granodiyorit için $439-615^{\circ} \mathrm{C}\left(535 \pm 51^{\circ} \mathrm{C}\right)$, mikrogranit için $427-648^{\circ} \mathrm{C}\left(523 \pm 83^{\circ} \mathrm{C}\right)$ ve lökogranit için $456-482^{\circ} \mathrm{C}\left(469 \pm 9^{\circ} \mathrm{C}\right)$ sıcaklık değerleri elde edilmiștir. Yine tüm kayaç tiplerinde bulunan dengedeki plajiyoklaz-alkali-feldispat mineral verileriyle iki feldispat termometresi (Benisek vd., 2004) uygulanmıș ve granodiyorit için $464-577^{\circ} \mathrm{C}$, mikrogranit için 464 $565^{\circ} \mathrm{C}$, lökogranit için ise $427-524^{\circ} \mathrm{C}$ değerleri elde edilmiștir. Feldispatların albitik ve anortitik içeriklerini Stormer (1975), Whitney ve Stormer (1977)'ın iki-feldispat grafiğinde belirledikleri sıcaklık eğrileriyle karșılaștırarak yapılan nitel yaklașım bu nicel değerleri desteklemiștir (Șekil 16d).

Denge koșulundaki hornblend-plajiyoklaz ve iki feldispata göre yapılan termometrik hesaplamalardan çıkan sonuçlar tek minerale bağlı sonuçlardan daha sağlıklı kabul edilebilir. Ancak bu çalıșmada, kullanılan termometrelerin tümünün uygun olduğu granodiyorit için biyotit-Ti ve iki feldispat termometreleri (sırasıly $427-648^{\circ}$ ve $427-565^{\circ} \mathrm{C}$ ) kısmen uyumlu değerler verirken hornblend-plajiyoklaz ve hornblend-Ti termometreleri daha yüksek ve geniș sıcaklık aralığı 
$\left(612-799^{\circ} \mathrm{C}\right)$ vermiștir. Hornblend-plajiyoklaz gibi termometrelerin verdiği solidus sıcaklığı genelde $>700^{\circ} \mathrm{C}^{\prime}$ dir (Anderson, 1996). Hornblend-plajiyoklaz termometresi ile elde edilen sıcaklığın solidus sıcakIığından $\left(\sim 700^{\circ} \mathrm{C}\right)$ daha düșük olması sub-solidus yeniden dengelenmeyi gösterir (Moazzen ve Droop, 2004). Bununla birlikte, feldispatların çoğunlukla sub-solidus yeniden dengelenmenin etkisinde kalabildiklerinden iki-feldispat termometresi kristallenme sıcaklığını vermez (Anderson, 1996). Sonuç olarak biyotit-Ti ve iki-feldispat termometrelerinden düșük sıcaklık değerleri feldispatların soğuma sırasında sub-solidus kristal içi değișim ile yeniden dengelendiklerini göstermektedir. Ayrıca, magmatik değerlerden sub-solidus değerlere geniș bir aralık veren amfibol-plajiyoklaz termometresi de yavaș soğuyan kayaçlarda geç evrede yeniden dengelenmenin varlığına ișaret etmektedir. Kırșehir civarında yüzeylenen granitoyidlerden yapılan jeotermometrik (hornblendplajiyoklaz: $698-853^{\circ} \mathrm{C}$, iki feldispat: $485-742^{\circ} \mathrm{C}$ ) değerlendirmeler de OAGnde sub-solidus yeniden dengelemenin var olduğunu göstermiștir (İlbeyli, 2005). Kırșehir bölgesi granitoyidlerinde yapılan diğer çalıșmalarda solidus sıcaklığın altında değerler vermiștir (600-680 C: Otlu vd., 2001; 590-695ㅇ: Boztuğ vd., 2008).

\section{Petrojenez}

Bu çalıșmada incelenen üç kayaç tipi de, tüm-kayaç elementel veriye göre sub-alkalen ve yüksek-K kalkalkalen özellikler sunmaktadır. Magmanın karakteri hakkında bilgi veren minerallerin kimyasal davranıșları (amfibol: $\mathrm{K}^{\mathrm{A}}-\mathrm{Al}{ }^{[4]}$ (Ridolfi ve Renzulle, 2012); biyotit: $\mathrm{FeO}_{(\mathrm{t})}-\mathrm{MgO}, \mathrm{FeO}_{(\mathrm{t})}-\mathrm{Al}_{2} \mathrm{O}_{3}, \mathrm{MgO}-\mathrm{Al}_{2} \mathrm{O}_{3}, \mathrm{MgO}-$ $\mathrm{FeO}_{(\mathrm{t})}-\mathrm{Al}_{2} \mathrm{O}_{3}$ (Abdel-Fattah, 1994, 1996)) da granitoyidlerin kalk-alkalen karakterlerini desteklemektedir. Granodiyorit $\mathrm{A} / \mathrm{CNK}<1.1$ ile metalüminalıdan peralüminalıya geçiș göstermekte olup hornblend ve titanit içermesiyle I-tipi granitoyid (Chappell vd., 1987) özellikleri göstermektedir. Biyotit kimyasına göre peralüminalı karakteri olan mikrogranitin bu özelliği A/CNK > 1.1 oranılla desteklenmiș olup bu kayaç Chappell ve White (1974) sınıflamasına göre S-tipi granitoyidlerin özelliğine uyum sağlamaktadır. 1.1'in altındaki A/CNK oranlarıyla zayıf peralüminalı özellik sunan lökogranit ise CIPW normatif korundum > 1.0 ile Chappell ve White (2001)'e göre S-tipidir. Lökogranitin düșük $\mathrm{A} / \mathrm{CNK}$ değerleri yoğun ortoklaz varlığı ve plajiyoklazların albitik bileșimde olması ile açıklanabilir. Mikrogranit ve lökogranitin S-tipi karakter- lerini, kayaçlarda hornblend olmaması ve iki mikalı (biyotit - birincil muskovit) olmaları desteklemektedir.

Biyotit ve amfibol bileșimindeki katyonların (Al(t), Ti, $\mathrm{Fe}$ ve $\mathrm{Mg}$ ) değișimi kayaçların türedikleri magmanın evrimi hakkında bilgi verebilmektedir (Slaby ve Martin, 2008) ki bu değișimler özellikle de biyotitin incelenen üç granitoyidde de bulunması nedeniyle çok önemlidir. Granodiyorit ve lökogranitteki biyotit katyonlarının Mg'ye karșı davranımları kayaçların farklı sistemlere ait olduklarına ișaret etmektedir (Șekil 12). İlk bakıșta granodiyoritten lökogranite hafif artan $\mathrm{Al}^{(\mathrm{t})}$ (fbb) gözlenmekte iken mikrogranit biyotitleri diğerlerine göre oldukça yüksek $\mathrm{Al}^{(t)}$ içeriği ile karakterize olmaktadır. Bunun yanısıra, değișen $\mathrm{Fe}^{(t)}$ 'ye ve hatta Mg'ye karșı hemen hemen sabit Ti değerleri farklı granitoyidlerin birbirleriyle magmatik fraksiyonlașma ilișkisi göstermediklerinin göstergesidir (Șekil 12). Çünkü biyotit ve amfibolde Mg\#'ye karșı Ti içeriğinin düșmesi fraksiyonel kristallenme yoluyla magma farklılașmasından kaynaklanmaktadır (Slaby ve Martin, 2008).

Kayaçlardaki biyotit katyonlarının Fe\#'ye karșı davranımları ve farklılașma eğrileri kayaçların kökensel farklııklarını sunduklarını göstermektedir (Șekil 17). Sadece granodiyoritte gözlenen amfibollerin de biyotitte olduğu gibi farklılașma gösteren Fe\# değerlerine sahip oldukları görülmektedir (Șekil 17). Aynı șekilde Fe\#'sına karșı $\mathrm{Al}^{(\mathrm{t})}$ ve Ti (fbb) dağılımlarına bakıldığında, amfibollerin değișken Ti ve $\mathrm{Al}^{(\mathrm{t})}$ (fbb) değerler gösterdikleri söylenebilir ki yukarıda bahsedildiği üzere iki grup amphibolün varlığına ișaret edebilir. Amfibollerde gözlenen bu tür element yer değișim mekanizmaları granodiyoritte farklı magma kaynaklarının karıșımına, dolayısıyla hibritleșmeye ișaret edebilir ki (Toksoy-Köksal vd., 2009b) (Șekil 17) saha ve petrografik gözlemlerle granodiyoritte saptanan bol miktardaki hornblend ve plajiyoklaz içeren, mafik mikrogranüler anklavların (MMA) varlığı, felsik ve mafik magmaların eș zamanlı olarak karıșımını, etkileșimini ve birlikte katılașmıș oldukları fikrini destekler (Barbarin ve Didier, 1992). Granodiyoritteki amfibole benzer șekilde biyotit ve plajiyoklazda belirlenen bileșimsel farklılıktan kaynaklanan iki grubun da yine magma kökeninde karıșıma / hibritleșmeye ișaret ettikleri (Toksoy-Köksal vd., 2009b) saptanmıștır.

Amfibol ve biyotitin katyonik davranıșlarını destekler șekilde, tüm-kayaç elementel değișim diyagramlarında da lökogranit, mikrogranit ve granodiyorit farklı eğilimler verdikleri görülmektedir (Șekil 6) ve kayaç- 

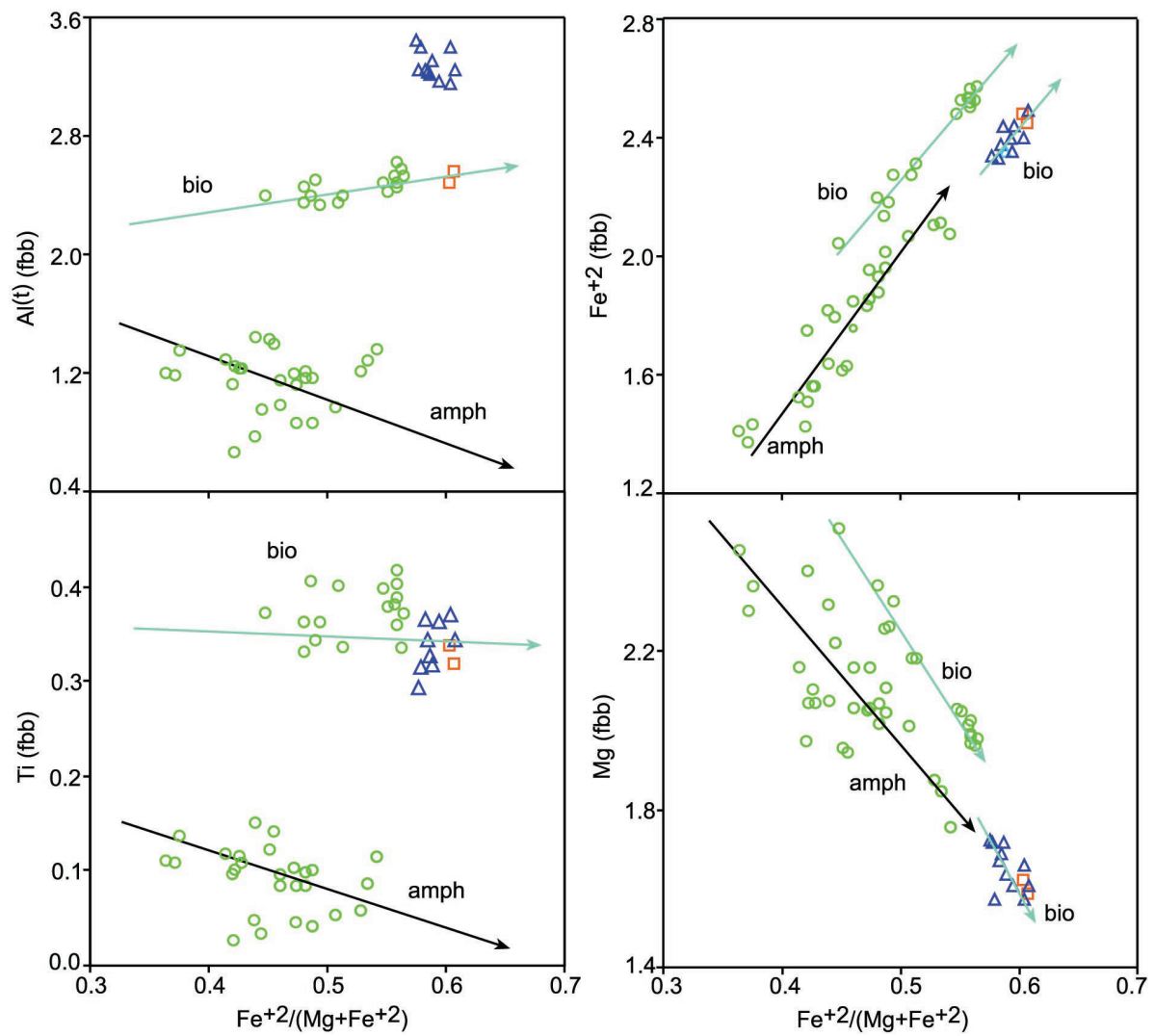

Șekil 17. Amfibol ve biyotit katyonlarının $\mathrm{Fe}^{+2} /\left(\mathrm{Fe}^{+2}+\mathrm{Mg}\right)^{\prime}$ ye karșı değișimi (amph: amfibol, bio: biyotit) (semboller için Șekil 4'e bakınız).

Figure 17. Plots of cations against $\mathrm{Fe}^{2+} /\left(\mathrm{Fe}^{2+}+\mathrm{Mg}\right)$ for amphibole and biotite (amph: amphibole, bio: biotite) (see Figure 4 for symbols).

ların farklı kökenlere sahip olduklarını akla getirmektedir. Granitoyidlerin çoklu iz element değișim diyagramlarında ve NTE karșılaștırmalarında farklı özellikler saptanmıștır ki bu da granitoyidler arasındaki kökensel farklılığı desteklemektedir. Lökogranit örnekleri hem hafif NTE'lerde $\left(\mathrm{La}_{\mathrm{N}}=35.02-81.43\right)$ hem de ağır NTE'lerde $\left(\mathrm{Yb}_{N}=14.16-31.68\right)$ diğer kayaçlara göre değișken olup, hafif NTE'ce düșük ağır NTE'ce yüksek değerler sunmaktadır. $(\mathrm{La} / \mathrm{Yb})_{\mathrm{N}}$ oranları (granodiyorit: 7.76-24.42; mikrogranit: 8.63-13.47; lökogranit: 1.76-3.13) granodiyorit ve mikrogranitte daha yüksek NTE fraksiyonlașmasına ve magma kaynağında granatın (Hauri vd., 1994; Petermann vd., 2003) ve/veya hornblendin varlığına (Tiepolo ve Tribuzio, 2008; Reichardt ve Weinberg, 2012) ișaret etmektedir. Bu da magma kaynağının granat-lerzolitik manto veya granatlı / hornblendli alt kıtasal kabuk olduğunu akla getirmektedir. Bunun yanısıra, 7.76'dan 24.42'ye geniș aralıkta değișen $(\mathrm{La} / \mathrm{Yb})_{N}$ granodiyoritin kökeninde hibritleșmenin göstergesi olabilir.
Evropiyum anomalileri mikrogranit için $\left[\mathrm{Eu} / \mathrm{Eu}^{*}\right]$ ${ }_{N}=0.63-0.78$, granodiyorit için $\left[E u / \mathrm{Eu}^{*}\right]_{N}=0.52-0.74$ ve lökogranit için ise $\left(\left[\mathrm{Eu} / \mathrm{Eu}^{*}\right]_{N}=0.09-0.21\right)$ șeklindedir. Lökogranit en belirgin Eu-negatif anomalisini gösterirken, granodiyorit de mikrogranite göre belirgin negatif Eu-anomalisi göstermektedir. Negatif Euanomalisi lökogranitte daha etkin olmak üzere tüm granitoyidlerde plajiyoklaz fraksiyonlașmasını önermektedir (Șekil 7).

Mikrogranitteki biyotitin düșük $\mathrm{Si}$ içeriğine karșın yüksek Al içermesi Shabani vd. (2003)'ne göre alimünyumca zengin kabuksal malzemeden katılıma ișaret etmektedir. Bunun yanısıra, peralümina karakterli mikrogranitte muskovitle birlikte bulunan biyotitlerin oldukça yüksek $\mathrm{A}^{\left[{ }^{[4]}\right]}$ içeriği (2.81-3.09 $\mathrm{fbb})$ ve düșük $\mathrm{Mg} /\left(\mathrm{Mg}+\mathrm{Fe}^{2+}\right)$ (Mg\#) (0.39-0.43 fbb) değerleri Kemp (2004)'e göre meta-sedimenter kabuksal kıta kısmi ergimesiyle olușan magmayı ișaret etmektedir (Șekil 18). Düșük Mg\# (0.39-0.40 fbb) ve kısmen düșük Al ${ }^{[4]}(2.42-2.50 \mathrm{fbb})$ değerleriyle meta- 
sedimenter ergiyik alanına yakın olan lökogranitteki muskovit birliktelikli biyotitlerin ise meta-sedimenter katkılı kıtasal kabuk kökenine ișaret ettikleri düșünülmektedir (Șekil 18). Hibritik karakterli granodiyoritin biyotitleri orta değerlerdeki $\mathrm{Al}^{[4]}(2.42-2.54 \mathrm{fbb})$ ve kısmen yüksek Mg\# (0.43-0.55) değerleriyle manto kaynaklı magma ürünü granitoyid biyotitlerine $\left(\mathrm{Al}^{[4]}=2.3-2.4 \mathrm{fbb}\right.$ ve $\left.\mathrm{Mg} \#>0.60\right)$ yakın olmakla birlikte farklılık göstermektedir (Șekil 18). Șekil 18'de de görüldüğü üzere granodiyorit biyotitleri manto kökenli ergiyik ile meta-sedimenter ergiyik karıșım eğrisinin dıșında kalmaktadır. Bu da kaynak kayanın tek bașına manto olamayacağını düșündürmektedir. Aksine sığ manto kaynaklı ergiyiğin kabuksal kaynaklı ergiyikle karıșması granodiyorit biyotitlerinin daha düșük Mg\# ve yüksek $\mathrm{Al}^{[4]}$ değerlere sahip olmasına yol açmıș olabilir. Bununla birlikte, tüm-kayaç element jeokimyasının da kaynakta granat / hornblend birikmesini ișaret ettiği dikkate alındığında sığ manto kaynak kayasının yanısıra granatlı kabuksal metamagmatik kayaçlar da hibritleșmiș bu granodiyoritik magmanın kaynağı olarak önerilebilir. Granodiyoritin kökeninde farklı kaynakların etkin olabileceği bu bileșenlerin de mantonun(?) yanısıra meta-magmatik ve meta-sedimenterden olușan kabuksal malzeme olabileceği düșünülebilir. Sr-Nd izotop verileri de az miktarda manto katkılı kıtasal kabuk kaynağına ișaret etmektedir (Toksoy-Köksal vd., 2009a). Bunun yanısıra, Toksoy-Köksal vd. (2009a)'de verilen zirkon Lu-Hf verileri $\left(\varepsilon \mathrm{Hf}_{(\mathrm{t})}:[-1.3 \pm 0.5]-[-8.8 \pm 0.5]\right.$ aralığı) de kıtasal kabuk değerleriyle eșleșmektedir. Köksal vd. (2012, 2013)'de OAKK granitoyidlerin kıtasal kabuk baskın kaynak özelliklerine dikkat çekmiștir. Granitik magma orta kıtasal kabuk meta-sedimenter kayaçların $\sim 750^{\circ} \mathrm{C}$ 'de dehidrasyon kısmi ergimesiyle olușabilmektedir (Harris ve Massey, 1994).

Granodiyoritin I-tipi özelliği meta-magmatik kabuğun ergimesini (Chappell vd., 1987) ve mikrogranit ile lökogranitin S-tipi karakteri ise meta-sedimenter kaynak kayanın ergimesini (Chappell ve White, 1974) önermektedir. Ancak tüm veriler toplu olarak değerlendirildiğinde EMB granitoyidlerini S- ve I-tipi granitler olarak sınıflamanın petrolojik açıdan tam olarak doğruyu yansıtmayacağı düșünülmektedir. Çünkü çoğunlukla I-tipi özellikler gösteren granodiyoritte kıtasal kabuk katkısı çok yüksek gözükürken, S-tipi özelliklere sahip lökogranit ve hatta mikrogranitte manto katkısının(?) da varlığı görülmektedir. Bu nedenle Gray (1984), Keay vd. (1997), Chen vd. (2016) gibi araștırmacıların da önerdiği gibi hem S-, hem de I-tipi Ekecikdağ granitoyidlerinin manto-kıtasal kabuk katkılı heterojen bir kaynaktan türediği savı önerilebilir. Zaten son yıllarda yapılan çalıșmalarda, S-tipi granitlerin kaynaklarında mantodan türemiș magmanın bulunabildiği gibi (Maas vd., 2001), I-tipi granitoyidlerin de kabuksal sedimenter malzemenin manto-benzeri magma ile tekrar çalıșması ile (Kemp vd., 2007) olușabileceği ortaya konulmuștur. Sonuç olarak, Ekecikdağ bölgesindeki granitoyidleri, kıtasal kabuk baskın kökenli ancak kaynağında granodiyoritte en fazla ve mikrogranitte en az olmak üzere manto katkısı(?) da içeren kayaçlar olarak nitelemek kabul edilebilir görülmektedir.

Chen vd. (2016) tarafından önerildiği üzere I-tipi granitik kayaçların kökeninde felsik-ortaç magmatik - metamorfik - sedimenter kayaç karıșımı kabuksal malzeme rol oynayabilir. Bu nedenle, özellikle granodiyoritin kökeninde diğer granitoyidlere göre daha baskın görünen mafik magma kaynağı manto veya meta-magmatik kabuksal malzeme olabileceği gibi ikisinin karıșımını da karakterize edebilir.

Yukarıda bahsedildiği üzere, Orta Anadolu'da pek çok çarpıșma ve çarpıșma sonrası gerilmeli ortamda gelișen granitoyid vardır ve temeli olușturan metamorfikleri ve ofiyolitik birimleri kesmektedirler. Șistik ve gnaysik meta-sedimenter kayaçlar yüksek sıcaklık orta basınç koșullarında (maksimum $700-770^{\circ} \mathrm{C} /$ 6-8 kbar) üst amfibolit fasiyesinde maksimum 20-26 km derinlikte (Whitney vd., 2001; Lefebvre vd., 2015)

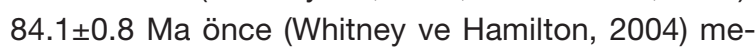
tamorfizmaya uğramıșlardır. Amfibolit fasiyesindeki bu metamorfizmayı düșük basınç (3-4 kbar) ortayüksek sıcaklık $\left(550-700^{\circ} \mathrm{C}\right)$ yeșilșist fasiyesine gerileyen metamofizma takip etmiștir (Whitney vd., 2001, 2003; Lefebvre vd., 2015). Basınç azalmasına bağlı gelișen gerileyen metamorfizmaya S-tipi granit sokulumu eșlik etmiștir (Whitney vd., 2001, 2003; Lefebvre vd., 2011, 2015). Meta-sedimenter birimlerden migmatit ve beraberindeki granitlerden yapılan çalıșmalar, bu granitik magmanın orta kıtasal kabuk meta-sedimenter kayaçların yüksek sıcaklık bölgesel metamorfizması sırasında ve/veya basınç azalmaya (<12km) bașladığında kısmi ergime gerçekleștiğini, ancak gerilmeli sistemde uzun süreli ergime ve yüksek sıcaklık metamorfizmasının devam etmediğini göstermiștir (Üçkapılı granitoyid: Whitney vd., 2003). Ergime, halihazırda sıcak olan temelin gerilmesini ve metasomatizmaya uğramıș mantoda basınç azalmasını (dekompresiyon) tetiklemiștir (Boztuğ vd., 2009; İlbeyli, 2005; Köksal vd., 2013). Litosferik delaminas- 


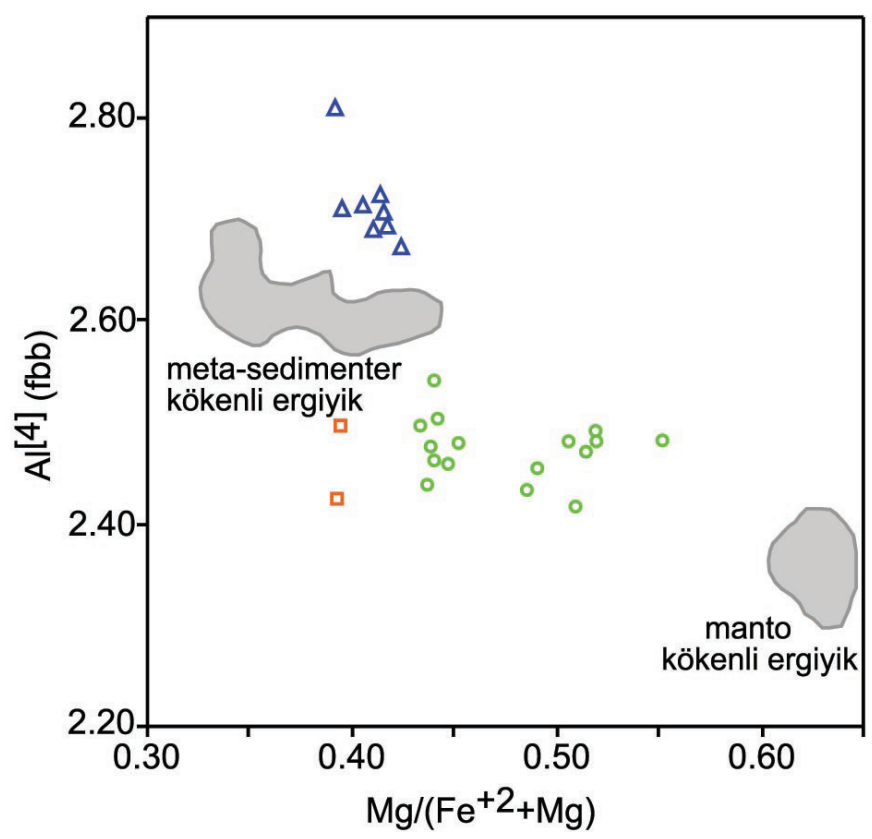

Șekil 18. EMB granitoyidlerindeki biyotitlerde $\mathrm{Al}^{[4]}$ değerlerinin $\mathrm{Mg} /\left(\mathrm{Mg}+\mathrm{Fe}^{+2}\right)^{\prime} \mathrm{e}$ karșı dağılımı ve bunların meta-sedimenter kökenli ergiyik ile manto kökenli orta-felsik karakterli ergiyikle karșılaștırmaları (meta-sedimenter ergiyik alanı Kemp (2001)'den, manto kökenli ergiyik alanı ise Kemp (2004)'den alınmıștır) (semboller için Șekil 4'e bakınız).

Figure 18. Plots of $\mathrm{Al}^{[4]}$ againts $\mathrm{Mg} /\left(\mathrm{Mg}+\mathrm{Fe}^{2+}\right)$ for biotites of the EMA granitoids and their comparison with biotites deriving from melts of meta-sedimentary rocks and felsic-intermediate melt of mantle source rock (melt of metasedimentary rocks from Kemp (2001), melt of mantle source from Kemp (2004)) (see Figure 4 for symbols).

yon veya dalan dilimin kırılması (slab breakoff) gibi süreçlerle sıcak astenosferin litosferik mantoya doğru yükselmesiyle bölgede olușan yüksek ısının manto ergimesine ve I-tipi granitoyid sokulumlara neden olduğu önerilmektedir (ílbeyli, 2005; Boztuğ vd., 2009; Köksal vd., 2012, 2013). I-tipi granitoyidlerin kökeninde kabuksal malzemenin de etkisi de vardır (illbeyli, 2005; Boztuğ vd., 2007b, 2009; Toksoy-Köksal vd., 2009a; Köksal vd., 2012, 2013).

\section{SONUÇLAR}

$\mathrm{Bu}$ çalıșmada; Aksaray (Orta Anadolu) yöresindeki Ekecikdağ Magmatik Birliği'nde yeralan granitik kayaçların tüm-kayaç element jeokimyası ve mineral kimyasına dayalı petrojenetik özellikleri ve magma kristalizasyon koșulları araștırılmıștır. Orta Anadolu'daki belli bașlı magmatik birliklerden birisi olan bu birlikteki granitlerin mineral kimyasal özellikleri kullanılarak jenetik ilișkilerinin belirlenmesi ve fiziko-kimyasal özelliklerinin ortaya konulması Orta Anadolu'nun jeolojik evrimine katkı sağlaması açısından önem tașımaktadır.
Ekecikdağ granitoyidleri arazi ve petrografik gözlemler, tüm-kayaç element ve mineral kimyası verilerine dayalı çalıșmalar baz alınarak granodiyorit, mikrogranit ve lökogranit olarak üç ana birime ayrılmıștır. Üç granitoyid de sub-alkalen ve yüksek potasyumlu kalk-alkalen nitelikte olmalarına karșın birbirlerinden farklı karakterlere sahiptirler. Granodiyorit metalüminalı, lökogranit zayıf peralüminalı ve mikrogranit peralüminalı özellik sunar. Ekecikdağ granitoyidlerinde ilksel mantoya göre normalize edilmiș çoklu-element dağılım grafiklerinde (lökogranitte daha belirgin olmak üzere) negatif $\mathrm{Ba}, \mathrm{Nb}, \mathrm{Sr}, \mathrm{P}$, Eu ve $\mathrm{Ti}$ anomalileri gözlenmektedir. Lökogranit diğer kayaçlara göre hafif NTE'ce düșük ağır NTE'ce yüksek değerler sunmaktadır. $(\mathrm{La} / \mathrm{Yb})_{\mathrm{N}}$ oranları granodiyorit ve mikrogranitte daha yüksek NTE fraksiyonlașmasına ve magma kaynağında granatın / hornblendin birikmesine ișaret etmektedir. NTE grafiklerinde gözlenen negatif Eu-anomalisi lökogranitte daha etkin olmak üzere tüm granitoyidlerde plajiyoklaz fraksiyonlașmasını önermektedir. Tüm-kayaç element-element değișim ile çoklu element grafikleri ve mineral katyon yer değișim diyagramları bu granitoyidlerin magma- 
nın gelișim süreci içerisinde giderek fraksiyonlașan ortak bir kaynaktan türemediklerini veya ortak heterojen kaynaktan farklı süreçlerle fraksiyonlaștıklarını ortaya koymaktadır.

Mineral kimyası özellikleri tüm-kayaç verisini destekler șekilde kayaçların birbirlerinden farklı kökenlere sahip olduklarını göstermektedir. Veriler ıșığında I- ve S-tipi EMB granitoyidlerinin magma kökeninde manto katkısının soru ișareti olup meta-magmatik ve/veya meta-sedimenter alt kıtasal kabuk katkısının önemli olduğu önerilmiștir. Petrografik ve jeolojik bulguları destekleyen mineral kimyası verileri granodiyoritin hibrid bir magmadan türediğine ișaret etmektedir.

Jeodinamik anlamda katkı sağlayacağı düșünülerek EMB granitoyidlerinde yapılan jeotermometrik hesaplamalar, granodiyorit için $615-783^{\circ} \mathrm{C}$ (hornblendplajiyoklaz ve hornblend-Ti termometreleri), mikrogranit için $464-565^{\circ} \mathrm{C}$ (biyotit-Ti ve iki feldispat termometreleri) ve lökogranit için ise $456-482^{\circ} \mathrm{C}$ (biyotit-Ti ve iki feldispat termometreleri) sıcaklık aralıklarını ortaya koymuștur. Genelde hornblend-plajiyoklaz termometresinin $>700^{\circ} \mathrm{C}$ solidus sıcaklığı verdiği ve feldispatların çoğunlukla sub-solidus yeniden dengelenmenin etkisinde kalabildikleri (Anderson, 1996) düșünülerek; bu çalıșmada magmatik değerlerden sub-solidus değerlere geniș aralıkta elde edilen sıcaklıkların yavaș soğuyan bu kayaçlarda geç evrede yeniden dengelenmeye ișaret ettikleri önerilmektedir. Minerallerde sub-solidus rekristalizasyona, Orta Anadolu'daki nispeten genç (yaklașık 75 milyon yıl) magmatizmanın (Köksal vd., 2004, 2013), Orta Anadolu'nun Eosen'de yükselmesinin ve/veya yine Eosen'de basen olușumuna dayalı volkanizmanın neden olmuș olabileceği düșünülmektedir.

Jeobarometrik hesaplamalar granodiyoritin yerleșim basıncının (3-4.5 kbar) dolayısıyla 10-16 km derinlikte yerleștiğini önermektedir. Mikrogranit ve lökogranite uygulanabilecek uygun jeobarometrik hesaplama mümkün olmadığından, bu granitoyidlerin yerleșim derinliği jeolojik ve teorik verilerle 11-12 km'ye sınırlandırımıștır. EMB granitoyidlerinin yerleșim derinliği orta kabuksal seviyelere karșılık gelmektedir.

\section{KATKI BELIRTME}

Bu çalıșma TÜBITAK tarafından 106 Y066 nolu proje kapsamında desteklenmiștir. Yazar değerli görüș ve katkılarından dolayı Orta Doğu Teknik Üniversitesi'nden M. Cemal Göncüoğlu ve Serhat
Köksal'a teșekkür eder. Yazar, ayrıca, yayını değerlendirip katkı sağlayan hakemler Sabah Yılmaz Șahin ve Faruk Aydın'a da teșekkür eder.

\section{KAYNAKLAR}

Abbott Jr., R.N., 1985. Muscovite-bearing granites in the AFM liquidus projection. Canadian Mineralogist, 23, 553-561.

Abdel-Fattah, M.A., 1994. Nature of biotites from alkaline, calc-alkaline, and peraluminous magmas. Journal of Petrology, 35, 525-541.

Abdel-Fattah, M.A., 1996. Discussion on the comment on nature of biotites in alkaline, calcalkaline, and peraluminous magmas. Journal of Petrology, 37, 1031-1035.

Ague, J.J., 1997. Thermodynamic calculation of emplacement pressures for batholithic rocks, California: implications for the aluminum-inhornblende barometer. Geology, 25, 563566.

Akıman, O., Erler, A., Göncüoğlu, M.C., Güleç, N., Geven, A., Türeli, T.K., and Kadıoğlu, Y.K., 1993. Geochemical characteristics of granitoids along the western margin of the Central Anatolian Crystalline Complex and their tectonic implications. Geological Journal 28, 371-382.

Anderson, J.L., 1996. Status of thermobarometry in granitic batholiths. Trans Royal Society Edinburgh, Earth Sciences, 87, 125-138.

Anderson, J.L., and Smith, D.R., 1995. The effects of temperature and $\mathrm{fO}_{2}$ on the Al-inhornblende barometer. American Mineralogist, 80, 549-559.

Andrade, S., Hypolito, R., Ulbrich, H.G.J., and Silva, M.L., 2002. Iron(II) oxide determination in rocks and minerals. Chemical Geology, 182, 85-89.

Aydın, N.S., Göncüoğlu, M.C., and Erler, A., 1998. Latest Cretaceous magmatism in the Central Anatolian Crystalline Complex: review of field, petrographic and geochemical features. Turkish Journal of Earth Sciences, 7, 259268.

Barbarin, B., and Didier, J., 1992. Genesis and evolution of mafic microgranular enclaves through various types of interaction between coexisting felsic and mafic magmas. Royal 
Society of Edinburgh, Transactions: Earth Sciences, 83, 145-153.

Barnes, C.G., and Prestvik, T., 2000. Condition of pluton emplacement and anatexis in the Caledonian Batholith, north-central Norway. Norsk Geologisk Tidsskrift, 80, 259-274.

Benisek, A., Kroll, H., and Cemië, L., 2004. New developments in two-feldspar thermometry. American Mineralogist, 89, 1496-1504.

Boztuğ, D., 1998. Post-collisional Central Anatolian alkaline plutonism, Turkey. Turkish Journal of Earth Sciences, 7, 145-165.

Boztuğ, D., 2000. S-I-A-type intrusive associations: geodynamic of significance of synchronism between metamorphism and magmatism in central anatolia, Turkey. In: tectonics and magmatism in Turkey and the surrounding area, Eds: Bozkurt E., Winchester J.A., and Piper J.D.A., Geological Society, London, Special Publications, 173, 441-458.

Boztuğ, D., Güney, Ö.Z., Heziler, M., Jonckheere, R.C., Tichomirowa, M., and Otlu, N., 2008. ${ }^{207} \mathrm{~Pb}-{ }^{206} \mathrm{~Pb},{ }^{40} \mathrm{Ar}-{ }^{39} \mathrm{Ar}$ and Fission-Track $\mathrm{Ge}$ othermochronology Quantifying Cooling and Exhumation History of the Kaman-Kırșehir Region Intrusions, Central Anatolia, Turkey. Turkish Journal of Earth Sciences, 18, 85-108.

Boztuğ, D., Harlavan, Y., Arehart, G.B., Satir, M., and Avci, N., 2007b. K-Ar age, whole-rock and isotope geochemistry of A-type granitoids in the Divriği-Sivas Region, Eastern-Central Anatolia, Turkey, Lithos, 97, 193-221.

Boztuğ, D., Jonckheere, R.C., Heizler, M., Ratschbacher, L., Harlavan, Y., and Tichomirova, M., 2009. Timing of post-obduction granitoids from intrusion through cooling to exhumation in central Anatolia, Turkey. Tectonophysics, 473, 223-233.

Boztuğ, D., Tichomirowa, M., and Bombach, K., 2007a. 207Pb-206Pb single-zircon evaporation ages of some granitoid rocks reveal continent-oceanic island arc collision during the Cretaceous geodynamic evolution of the central Anatolian crust, Turkey. Journal of Asian Earth Sciences, 31, 71-86.

Brown, E.H., 1977. The crossite content of Caamphiboles as a guide to pressure of metamorphism. Journal of Petrology, 18, 53-72.
Chappell, B.W., and White, A.J.R., 1974. Two contrasting granite types. Pacific Geology, 8, 173-174.

Chappell, B.W., and White, A.J.R., 2001. Two contrasting granite types: 25 years later. Australian Journal of Earth Sciences, 48, 489-499.

Chappell, B.W., White, A.J.R., and Wyborne, D., 1987. The importance of residual source material (restite) in granite petrogenesis. Journal of Petrology, 28, 1111-1138.

Chatterjee, N.D., and Johannes, W., 1974. Thermal stability and standard thermodynamic properties of synthetic $2 \mathrm{M}_{1}$-muscovite, $\mathrm{KAl}_{2}\left(\mathrm{AISi}_{3}\right) \mathrm{O}_{10}(\mathrm{OH})_{2}$. Contirbutions to Mineralogy and Petrology, 48, 89-114.

Chen, W., Xu, Z., Chen, M., and Yu, Y., 2016. Multiple sources for the origin of the early Cretaceous Xinxian granitic batholith and its tectonic implications for the western Dabie orogeny, eastern China. Mineralogy and Petrology, 110, 29-41.

Deer, W.A., Howie, R.A., and Zussman, J., 1980. Introduction to the Rock Forming Minerals. Longman, London.

Delibaș, O., Genç, Y., and De Campos, C.P., 2011. Magma mixing and unmixing related mineralization in the Karacaali Magmatic Complex, central Anatolia, Turkey. In: Granite-Related Ore Deposits, Sial, A.N., Bettencourt, J.S., De Campos, C.P. (eds.), Geological Society, London, Special Publications, 350, 149-173.

Deniz, K., and Kadıoğlu, Y.K., 2016. Assimilation and fractional crystallization of foid-bearing alkaline rocks: Buzlukdağ intrusives, Central Anatolia, Turkey. Turkish Journal of Earth Sciences, 25, 341-366.

Droop, G.T.R., 1987. A general equation for estimating $\mathrm{Fe}^{3+}$ concentrations in ferromagnesian silicates and oxides from microprobe analysis, using stoichiometric criteria. Mineralogical Magazine, 51, 431-437.

Düzgören-Aydın, N.S., Malpas, J., Göncüoğlu, M.C., and Erler, A., 2001. A review of the nature of magmatism in central Anatolia during the mesozoic post-collisional period. International Geological Review, 43, 695-710.

Enami, M., Suzuki, K., Liou, J.G., and Bird, D.K., 1993. $\mathrm{Al}-\mathrm{Fe}^{3+}$ and $\mathrm{F}-\mathrm{OH}$ substitutions in titanite 
and constrains on their P-T dependence. European Journal of Mineralogy, 5, 231-291.

Erler, A., and Göncüoğlu, M.C., 1996. Geologic and tectonic setting of the Yozgat Batholith, northern Central Anatolian Crystalline Complex, Turkey. International Geological Review, 38, 714-726.

Erler, A., Akıman, O., Unan, C., Dalkılıç, B., Geven, A., and Önen, P., 1991. The petrology and geochemisty of the Kırșehir massif magmatic rocks in Kaman (Kırșehir) and Yozgat regions. Doğa-Türk Yerbilimleri Dergisi, 15, 76-100.

Foster, M.D., 1960. Interpretation of the composition of trioctahedral micas. U.S. Geological Survey, Professional Paper, 354-B, 11-49.

Frost, B.R., 1991. Introduction to oxygen fugacity and its petrologic significance. In: Reviews in Mineralogy: Oxide Minerals: Petrologic and Magnetic Significance, Ed: Lindsley, D.H., Mineralogical Society of America, 25, 1-10.

Göncüoğlu, M. C., Erler, A., Toprak, V., Olgun, E., Yalınız, K., Kușçu, İ., Köksal, S., and Dirik, K., 1993. Geology of the central part of the Central Anatolian Massif: part III geological evolution of the Tertiary Basin of the central Kızılırmak. Turkish Petroleum Company, Report No: 3313, Ankara (yayımlanmamıș).

Göncüoğlu, M. C., Erler, A., Toprak, V., Yaliniz, K., Olgun, E., and Rojay, B., 1992. Geology of the western part of the Central Anatolian Massif: Part II central part. Turkish Petroleum Company, Report No: 3155, Ankara (yayımlanmamıș).

Göncüoğlu, M.C., Kozlu, H., and Dirik, K. 1997. PreAlpine and Alpine terranes in Turkey: explanatory notes to the terrane map of Turkey. Ann. Geol. Pays Helleniques, 37, 515-536.

Göncüoğlu, M.C., Köksal, S., and Floyd, P.A., 1997. Post-collisional A-type magmatism in the Central Anatolian Crystalline Complex: petrology of the İdiș Dağı Intrusives (Avanos, Turkey). Turkish Journal of Earth Sciences, 6(2), 65-76.

Göncüoğlu, M.C., Köksal, S., ve Toksoy-Köksal, F., 2004. Zirkon tipolojisi ile granit petrojenezinin araștırılması yönteminin Orta Anadolu Granitoyidlerine uygulanması. TÜBiTAK, No: 101Y051, Ankara (yayımlanmamıș).
Göncüoğlu, M. C., Toprak, G.M.V., Kușçu, İ., Erler, A., and Olgun, E., 1991. Geology of the western part of the Central Anatolian Massif: part I southern part. Turkish Petroleum Company, Report No: 2909, Ankara (yayımlanmamıș).

Göncüoğlu, M.C., and Türeli, T.K., 1993. Petrology and geodynamic setting of plagiogranites from Central Anatolian Ophiolites (AksarayTurkiye). Turkish Journal of Earth Sciences, 2, 195-203.

Göncüoğlu, M.C., and Türeli, T.K., 1994. Alpine collision-tipi granitoyidis in the western Central Anatolian Crystalline Complex. Journal of Kocaeli University, 1, 39-46.

Görür, N., Oktay, F.Y., Seymen, İ., Șengör, A.M.C., 1984. Paleotectonic evolution of Tuzgölü Basin Complex, central Turkey. In: The geological evolution of the Eastern Mediterranean, Eds: Dixon J.E., Robertson A.H.F., Geological Society of London, Special Publications, 17, 81-96.

Gray, C.M., 1984. An isotopic mixing model for the origin of granitic rocks in southeastern Australia. Earth and Planetary Science Letters, 70, 47-60.

Haggerty, S.E., 1976. Opaque mineral oxides in terrestrial igneous rocks. Mineralogical Society of America Short Course Notes, 3,101-300.

Hammastrom, J.M., and Zen, E., 1986. Aluminium in Hornblende: An empirical igneous geobarometer. American Mineralogist, 71, 12971313.

Harris, N., and Massey, J., 1994. Decompression and anatexis of the Himalayan metapelites. Tectonics, 13, 1537-1546.

Harris, M.J., Symons, D.T.A., Blackburn, W.H., and Hart, C.J.R., 1999. Paleomagnetic and geobarometric study of the Late Cretaceous Mount Lorne Stock, southern Yukon Territory. Canadian Journal of Earth Sciences, 36, 905-915.

Haselton, H.T., Hovis, G.L., Hemingway, B.S., and Robie, R.A., 1983. Calorimetric investigation of the excess entropy of mixing in analbite-sanidine solid solutions: lack of evidence for $\mathrm{Na}, \mathrm{K}$ short-range order and implications for two-feldspar thermometry. American Mineralogist, 68, 398-413.

Hauri, E.H., Wagner, T.P. and Grove, T.L., 1994. Experimental and natural partitioning of Th, $U$, 
$\mathrm{Pb}$ and other trace elements between garnet, clinopyroxene and basaltic melts. Chemical Geology 117, 149-166.

Helmy, H.M., Ahmed, A.F., El Mahallawi, M.M., and Ali, S.M., 2004. Pressure, temperature and oxygen fugacity conditions of calc-alkaline granitoids, Eastern Desert of Egypt, and tectonic implications. Journal of African Earth Sciences, 38, 255-268.

Hinsbergen van, D.J.J., Maffione, M., Plunder, A., Kaymakcı, N., Ganerød, M., Hendriks, B.W.H., Corfu, F., Gürer, D., de Gelder, G.I.N.O., Peters, K., McPhee, P.J., Brouwer, F.M., Advokaat, E.L., and Vissers, R.L.M., 2016. Tectonic evolution and paleogeography of the Kırșehir Block and the Central Anatolian Ophiolites, Turkey. Tectonics, 35, 983-1014.

Holland, T.J.B., and Blundy, J., 1994. Non-ideal interactions in calcic amphiboles and their bearing on amphibole-plagioclase thermometry. Contributions to Mineralogy and Petrology, 116, 433-447.

Hollister, L.S., Grissom, G.C., Peters, E.K., Stowell, H.H., and Sisson, V.B., 1987. Confirmation of the empirical correlation of $\mathrm{Al}$ in hornblende with pressure of solidification of calcalkaline plutons. American Mineralogist 72, 231-239.

Irvine, T.N., and Baragar, W.R.A., 1971. A guide to the geochemical classification of the common volcanic rocks. Canadian Journal of Earth Sciences, 8, 523-548.

İlbeyli, N., 2005. Mineralogical-geochemical constraints on intrusives in Central Anatolia, Turkey: tectono-magmatic evolution and characteristics of mantle source. Geological Magazine, 142, 187-207.

İlbeyli, N., Pearce, J.A., Thirlwall, M.F., and Mitchell, J.G., 2004. Petrogenesis of collision-related plutonics in central Anatolia, Turkey. Lithos, 72, 163-182.

Johnson, M.C., and Rutherford, M.J., 1989. Experimental calibration of the aluminum-inhornblende geobarometer with application to Long Valley Caldera California volcanic rocks. Geology, 17, 837-841.

Kadıoğlu, Y.K., Dilek, Y., and Foland, K.A., 2006. Slab break-off and syncollisional origin of the
Late Cretaceous magmatism in the Central Anatolian Crystalline Complex, Turkey. In: Postcollisional tectonics and magmatism in the Mediterranean Region and Asia, Eds: Dilek Y., and Pavlides S., Geological Society of America, Special Paper, 409, 381-415.

Kadıoğlu, Y.K., Dilek ,Y., Güleç, N., and Foland, K.A., 2003. Tectonomagmatic evolution of bimodal plutons in the Central Anatolian Crystalline Complex, Turkey. Journal of Geology, 111, 671-690.

Keay, S., Collins, W.J., and Mcculloch, M.T., 1997. A three component Sr-Nd mixing model for granitoid genesis, Lachlan Fold Belt, Eastern Australia. Geology, 25, 307-310.

Kemp, A.I.S., 2001. Petrogenesis of granitic rocks: A source based perspective. PhD Thesis, Autralian National University, Canberra, Australia (yayımlanmamıș).

Kemp, A.I.S., 2004. Petrology of high-Mg, low-Ti igneous rocks of the Glenelg River Complex (SE Australia) and the nature of their interaction with crustal melts, Lithos, 119-156.

Kemp, A.I.S., Hawkesworth, C.J., Foster, G.L., Paterson, B.A., Woodhead, J.D., Hergt, J.M., Gray, C.M., and Whitehouse, M.J., 2007. Magmatic and crustal differentiation history of granitic rocks from $\mathrm{Hf}-\mathrm{O}$ isotopes in zircon. Science, 315, 980-983.

Köksal, S., 2005. Zircon typology and chemistry of the granitoids from Central Anatolia, Turkey. PhD Thesis, Middle East Technical University, Ankara (yayımlanmamıș).

Köksal, S., and Göncüoglu M.C., 2008. Sr and Nd isotopic characteristics of some S-, I- and A-type granitoids from central Anatolia. Turkish Journal of Earth Sciences, 17, 111-127.

Köksal, S., Göncüoğlu, M.C., and Floyd, P.A., 2001. Extrusive members of postcollisional A-type magmatism in central Anatolia: Karahidir Volcanics, Idisdagi-Avanos Area, Turkey. International Geological Review, 43, 683-694.

Köksal, S., Möller, A., Göncüoglu, M.C., Frei, D., and Gerdes, A., 2012. Crustal homogenization revealed by $\mathrm{U}-\mathrm{Pb}$ zircon ages and $\mathrm{Hf}$ isotope evidence from the Late Cretaceous granitoids of the Agaçören intrusive suite (Central Anatolia/Turkey). Contributions to Mineralogy and Petrology, v: 163, 725-743. 
Köksal, S., Romer, R.L., Göncüoğlu, M.C., and Toksoy-Köksal, F., 2004. Timing of postcollisional H-Tipi to A-Tipi granitic magmatism: U-Pb titanite ages from Alpine Central Anatolian Granitoyids (Turkey). International Journal of Earth Sciences, 93, 974-989.

Köksal, S., Toksoy-Köksal, Fatma; Goncuoglu, M. C., Moller, A., Gerdes, A., and Frei, D., 2013. Crustal source of the Late Cretaceous Satansari monzonite stock (central Anatolia - Turkey) and its significance for the Alpine geodynamic evolution. Journal of Geodynamics, 65, 82-93.

Leake, B.E., Woolley, A.R., Arps, C.E.S., Birch, W.D., Gilbert, M.C., Grice, J.D., Hawthorne, F.C., Kato, A., Kisch, H.J., Krivovichev, V.G., Linthout, K., Larid, J., Mandarino, J.A., Maresch, W.V., Nickel, E.H., Rock, N.M.S., Schmacher, J.C., Smith, D.C., Stephenson, N.C.N., Ungaretti, L., Whittaker, E.J.W., and Youzhi, G., 1997. Nomenclature of amphiboles: Report of the subcommittee on amphiboles of the International Mineralogical Association, commission on new minerals and mineral names. American Mineralogist, 82, 10191037.

Lefebvre, C., Barnhoorn, A., van Hinsbergen, D.J.J., Kaymakci, N., and Vissers, R.L.M., 2011. Late Cretaceous extensional denudation along a marble detachment fault zone in the Kırșehir massif near Kaman, central Turkey. Journal of Structural Geology, 33, 12201236.

Lefebvre, C., Peters, K., Wehrens, P., Brouwer, F.M., and van Roermund H.L.M., 2015. Thermal and extensional exhumation history of a high-temperature crystalline complex (Hırkadağ Massif, Central Anatolia). Lithos, 238, 156-173.

Maas, R., Kamenetsky, V., Nicholls, I.A., and Steele, D., 2001. The petrogenesis of mafi c S-type magmas: quenched melt inclusions in phenocrysts of a Silurian dacite (Lachlan Fold Belt). In: S-Type Granites and Related Rocks, Chappell, BW., and Fleming, P.D. (eds.). Australian Geological Survey Organisation Record, 2001/02, 77-78.

Maniar, P.D., and Piccoli, P.M., 1989. Tectonic discrimination of granitoids. Geological Society of America Bulletin, 101, 635-643.
Moazzen, M., and Droop, G.T.R., 2004. Application of mineral thermometers and barometers to granitoid igneous rocks: the Etive Complex, W Scotland. Mineralogy and Petrology, 83, 27-53.

Okay, A.I., Satir, M., Maluski, H., Siyako, M., Monié, P., Metzger, R., and Akyüz, S., 1996. Paleoand Neo-Tethyan events in northwestern Turkey: Geologic and geochronologic constraints. In: The Tectonic Evolution of Asia, Yin, A., and Harrison, T.M. (eds), Cambridge Univ. Press, Cambridge, U.K., 420-441.

Otlu, N., and Boztuğ, D., 1998. The coexistence of the silica oversaturated (alkos) and undersaturated (alkus) rocks in the Kortundag and Baranadag plutons from the Central Anatolian Alkaline Plutonism, E Kaman/NW Kirsehir, Turkey. Turkish Journal of Earth Sciences, 7, 241-257.

Otlu, N., Boztuğ, D., and Bonin, B., 2001. Mineral chemistry and geothermobarometry of some silica oversaturated alkaline plutons from the post-collisional alkaline plutonism in Central Anatolia, Turkey. Fourth International Turkish Geology Symposium, (ITGSIV),24-28 September 2001, Abstracts, p. 56.

Peccerillo, A., and Taylor, S.R., 1976. Geochemistry of Eocene calcalkaline volkanic rocks from Kastamonu area, northern Turkey. Contributions to Mineralogy and Petrology, 58, 63-81.

Petermann, M., Hirschmann, M.M., Hametner, K., Gunther, D., and Schmidt, M.W., 2003. Experimental determination of trace element partitioning between garnet and silica-rich liquid during anhydrous partial melting of MORB-like eclogite. Geochemistry, Geophysics, Geosystems, 5, doi: 10.1029/2003gc000638.

Pitcher, W.S., 1993. The Nature and Origin of Granite. Blackie Academic and Professional, Glasgow and London, $321 \mathrm{pp}$.

Pouchou, J.L., and Pichoir, F., 1991. Quantitative analysis of homogeneous or stratified microvolumes: applying the model "PAP". In: Electron Probe Quantification, Heinrich, K.F.J., and Newbury, D.E. (Eds), Plenum Press, New York, 31-75

Reichardt, H., and Weinberg, R.F., 2012. The dike swarm of the Karakoram shear zone, La- 
dakh, NW India: Linking granite source to batholith. Geological Society of America Bulletin, 124, 89-103.

Ridolfi, F., and Renzulli, A., 2012. Calcic amphiboles in calc-alkaline and alkaline magmas: thermobarometric and chemometric empirical equations valid up to $1,130^{\circ} \mathrm{C}$ and $2.2 \mathrm{Gpa}$. Contributions to Mineralogy and Petrology, 163, 877-895.

Ridolfi, F., Renzulli, A., and Puerini, M., 2010. Stability and chemical equilibrium of amphibole in calc-alkaline magmas: an overview, new thermobarometric formulations and application to subduction-related volcanoes. Contibution to Mineralogy and Petrology, 160, 45-66.

Rieder, M., Cavazzini, G., D’yakonov, Y.S., FrankKamenetskii, V.A., Gottardi, G., Guggenheim, S., Koval, P.V., Müller, G., Neiva, A.M.R., Radoslovich, E.W., Robert, J.-L., Sassi, F.P., Takeda, H., Weiss, Z., and Wones, D.R., 1998. Nomenclature of the micas. Canadian Mineralogist, 36, 905-912.

Schmidt, M.W., 1992. Amphibole composition in tonalite as a function of pressure: an experimental calibration of the Al-in hornblende barometer. Contributions to Mineralogy and Petrology, 110, 304-310.

Shabani, A.A.T., Lalonde, A., and Whalen, J.B., 2003. Composition of biotite from granitic rocks of the Canadian Appalachian Orogen: A potential tectonomagmatic indicator? Canadian Mineralogist, 41, 1381-1396.

Shand, S.J., 1943. Eruptive Rocks: their Genesis, Composition, Classification, and their Relation to Ore-Deposits with a Chapter on Meteorite. John Wiley and Sons, New York.

Slaby, E., and Martin, H., 2008. Mafic and felsic magma Interaction in granites: the Hercynian Karkonosze Pluton (Sudetes, Bohemian Massif). Journal of Petrology, 49, 353-391.

Stormer, J.C., Jr., 1975. A practical two-feldspar geothermometer. American Mineralogist, 60, 667-674.

Sun, S.S., and Mcdonough, W.F., 1989. Chemical and isotopic systematics of ocean basalts: Implication for mantle composition and processes. In: Magmatism in Ocean Basins, Saunders A.D., Norry M.J. (eds), 42, Geolo- gical Society of London, Special Publication, 313-345.

Șengör, A.M.C., and Yılmaz, Y., 1981. Tethyan evolution of Turkey: a plate tectonic approach. Tectonophysics, 75, 181-241.

Tatar, S., and Boztuğ, D., 1998. Fractional crystallization and magma mingling/mixing processes in the monzonitic association in the SW part of the composite Yozgat batholith (Șefaatli-Yerköy, SW Yozgat). Turkish Journal of Earth Sciences, 7, 215-230.

Thompson, A.B., 1974. Calculation of muscoviteparagonite-alkali-feldspar phase relations. Contributions to Mineralogy and Petrology, 44, 173-194.

Tiepolo, M., and Tribuzio, R., 2008. Petrology and $\mathrm{U}-\mathrm{Pb}$ zircon geochronology of amphibolerich cumulates with sanukitic affinity from Husky Ridge (northern Victoria Land, Antarctica); insights into the role of amphibole in the petrogenesis of subduction-related magmas. Journal of Petrology 49, 937-970.

Toksoy-Köksal, F., Gerdes, A., Göncüoğlu, M.C., Möller, A., Frei, D., and Köksal, S., 2009a. $\mathrm{U}-\mathrm{Pb}$ age and isotope data from the $\mathrm{S}$ - and I-type syn-collisional granites in the Ekecikdag area, central Anatolia. Geochim. Cosmochim Acta, 73, Suppl. S Goldschmidt 2009, A1335.

Toksoy-Köksal, F., Oberhaensli, R., and Göncüoglu, M.C., 2009b. Hydrous aluminosilicate metasomatism in an intra-oceanic subduction zone: Implications from the Kurancali ultramafic-mafic cumulates within the Alpine Neotethys Ocean, Turkey. Mineralogy and Petrology, 95, 273-290.

Toksoy-Köksal, F., Köksal, S., ve Göncüoğlu, M.C., 2008. Zirkon Jeokronolojisi ve Mineral Kimyası Çalıșmaları ile Ekecikdağ Mağmatik Birliği (Orta Anadolu) Granitoyidlerinin Yașı, Petrojenezi ve Jeodinamik Koșullarının Araștırılması. TÜBiTAK, Proje No: 106Y066, Ankara (yayımlanmamıș).

Türeli, T.K., 1991. Geology, petrography and geochemistry of Ekecikdağ (Aksaray) Plutonic Rocks. PhD Thesis, Middle East Technical University, Ankara, (yayımlanmamıș).

Türeli, T.K., Göncüoğlu, M.C., ve Akıman, O., 1993. Ekecikdağ granitoyidinin petrolojisi ve kö- 
keni (Orta Anadolu Kristalen Kütlesi batısı). Maden Tetkik ve Arama Dergisi, 115, 15-28.

Whitney, D.L., and Hamilton, M.A., 2004. Timing of high grade metamorphism in central Turkey and the assembly of Anatolia. Journal of the Geological Society, London, 161, 823-828.

Whitney, D.L., Teyssier, C., Dilek, Y., and Fayon, A.K., 2001. Metamorphism of the Central Anatolian Crystalline Complex, Turkey: influence of orogen-normal collision vs. wrenchdominated tectonics on P-T-t paths. Journal of Metamorphic Geology, 19, 411-432.

Whitney, D.L., Teyssier, C., Fayon, A.K., and Hamilton, M.A., Heziler, M., 2003. Tectonic controls on metamorphism, patial melting, and intrusion; timing and duration of regional metamorphism and magmatism in the Niğde Masif, Turkey. Tectonophsics 376, 37-60.

Whitney, J.A., and Stormer, J.C., Jr., 1977. The distribution of $\mathrm{NaAISi}_{3} \mathrm{O}_{8}$ between coexisting microcline and plagioclase and its effect on geothermometric calculations. American Mineralogist, 62, 687-691.

Wones, D.R., 1989. Significance of the assemblage titanite + magnetite + quartz in granitic rocks. American Mineralogist, 74, 744-749.
Wones, D.R., and Eugster, H.P., 1965. Stability of biotite: Experiment, theory and applications. American Mineralogist, 50, 1228-1272.

Wyllie, P.J., 1984. Constraints imposed by experimental petrology on possible and impossible magma sources and products. Philosophical Transactions of the Royal Society, A310, 439-456.

Yalınız, M.K., and Göncüoğlu, M.C., 1998. General geological characterictics and distribution of Central Anatolian Ophiolites. H.U. Yerbilimleri, 20, 19-30.

Yalınız, M.K., Aydın, N.S., Göncüoğlu, M.C., and Parlak, O., 1999. Terlemez quartz monzonite of central Anatolia (Aksaray-Sarıkaraman): age, petrogenesis and geotectonic implications for ophiolite emplacement. Geological Journal, 34, 233-242.

Yılmaz, S., and Boztuğ, D., 1998. Petrogenesis of the Çiçekdağ Igneous Complex, north of Kırșehir, Central Anatolia, Turkey. Turkish Journal of Earth Sciences, 7, 185-199.

Zen, E.-An, 1989. Plumbing the depths of batholiths. American Journal of Science, 289, 11371157. 